 \\ LES 8/9 Vibration Test on a Multihundred Watt FSA
}

\author{
C. G. Anderson and C. O. Brewer
}

Mạy 2, 1974

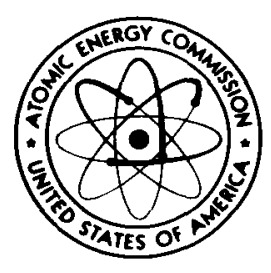

\section{MOUND LABORATORY}

Miamisburg, Ohio

operated by

\section{MONSANTO RESEARCH CORPORATION} a subsidiary of Monsanto Company for the

\section{U. S. ATOMIC ENERGY COMMISSION}

U. S. Government Contract No. AT-33-1-GEN-53 


\section{DISCLAIMER}

This report was prepared as an account of work sponsored by an agency of the United States Government. Neither the United States Government nor any agency Thereof, nor any of their employees, makes any warranty, express or implied, or assumes any legal liability or responsibility for the accuracy, completeness, or usefulness of any information, apparatus, product, or process disclosed, or represents that its use would not infringe privately owned rights. Reference herein to any specific commercial product, process, or service by trade name, trademark, manufacturer, or otherwise does not necessarily constitute or imply its endorsement, recommendation, or favoring by the United States Government or any agency thereof. The views and opinions of authors expressed herein do not necessarily state or reflect those of the United States Government or any agency thereof. 


\section{DISCLAIMER}

Portions of this document may be illegible in electronic image products. Images are produced from the best available original document. 


\title{
LES 8/9 Vibration Test on a Multihundred Watt FSA
}

\author{
C. G. Anderson and C. 0. Brewer
}

Is sued: May 2, 1974

\section{NOTICE}

This report was prepared as an account of work sponsored by the United States Government Neither the United States nor the United Stotes Atomic Energy Com mission, nar any of their employees, nor any of the ir contractors, subcontractors, or their employees, mokes any warranty, express or implied, or assumes any legal liability or responsibility for the accuracy, completeness or usefulness of any information, apporatus, product or process disclosed, or represents that its use would not infringe privote'y owned rights

PRINTED IN THE UNITED STATES OF AMERICA Avuilable from National Techrical information Service

U S Department of Commerce 5285 Porr Royal Rood

Spungfield Virg nia 22151 $M$ crof the $\$ 145$

\section{MONSANTO RESEARCH CORPORATION}

A Subsidiary of Monsanto Company

\section{MOUND LABORATORY}

Miamisburg, Ohio

45342

operated for

UNITED STATES ATOMIC ENERGY COMMISSION

US Government Contract No AT-33-1-GEN-53 
A random vibration test was performed on a ${ }^{23}{ }^{8} \mathrm{PuO}_{2}$ fueled Multihundred watt (MHW) fuel sphere assembly (FSA). The FSA (MHFT-11) was mounted in a Mound Laboratory test fixture and subjected to sinusoidal and random vibration energies on three orthogonal axes while in a simulated operational condition. The FSA temperature was maintained at $1000^{\circ} \mathrm{C}$ during the vibration test. Visual and radiographic inspections subsequent to the test indicated no apparent degradation of the FSA. 
The MHFT-1l fuel sphere assembly (FSA) was vibrated to determine its ability to withstand the vibration environment levels expected to be encountered during the powered flight phase of a Titan III C vehicle during a LES $8 / 9$ launch. The tests were designed to evaluate the effect of the graphite/metal and metal/fuel clearances as well as vent performance. Safety considerations and dynamic response characteristics were incorporated into the test fixture.

The original test requested was a LES $8 / 9$ qualification-level test utilizing a ${ }^{238} \mathrm{PuO}_{2}$ fueled FSA (MHFT-11). Pre- and post-baseline tests were conducted. General Electric, Energy Systems Program (GE/ESP) provided Monsanto Research Corporation, Mound Laboratory (Mound) with a modified LES $8 / 9$ qualification-level spectrum (Schedule A). This schedule reflects vibrations input to an FSA as observed during a generator-simulated shaker test on a heat source assembly conducted at GE/ESP.

GE/ESP analyzed the Mound vibration data for Runs 1-2l which used Schedule A. After this data reduction, schedule B was provided to Mound. Schedule $B$ was a qualification test schedule that took into account the transmittance responses of the Mound test fixture. Schedule B was used by Mound for the tests on MHFT-11, Runs 22-27.

Schedule $C$ was submitted to Mound by GE/ESP as an acceptance test schedule for LES $8 / 9$ after data reduction indicated Schedule $B$ was valid as a qualification test. Schedule $C$ was used for the dynamic tests which were performed subsequent to the $\mathrm{PuO}_{2}$ fueled tests on the seven fueled safety sequential test (SST) units.

The test data, as well as the inspections conducted after the tests, indicated that the FSA is satisfactory for its intended use. 
A. Test Plan

1. Alpha Fuels Environmental Test Facility . . . . . . . . 5

2. Health Physics Procedure for the Vibration Test of the Pioneer Source. . . . . . . . . . . . . . . . . . 13

B. Test Run Summary Sheet. . . . . . . . . . . . . . . . . . 17

C. Random Vibration Schedules. . . . . . . . . . . . . . . . . 19

D. Data Sheets . . . . . . . . . . . . . . . . . . . . . 21

E. Post-Test Inspection Comments . . . . . . . . . . . . . . . 63

F. Safety Sequential Test Documentation. . . . . . . . . . . . . 87

G. Radiographs and Photographs . . . . . . . . . . . . . . . 89 
ATTACHMENT A

1. ALPHA FUELS ENVIRONMENTAL TEST FACILITY

\section{Fueled FSA Fixture Vibration Test Procedure}

The fueled FSA fixture shall be subjected to a vibration environment to determine its ability to withstand the specified vibration levels and duration.

\subsection{Objectives}

To evaluate the performance of an FSA under the LES $8 / 9$ vibration environment, such as would be encountered during the powered flight phase of a Titan III C launch vehicle.

a) Evaluate the effect of the clearance between the fuel sphere and the PISA (post-impact sphere assembly) on the integrity of the fuel sphere, particularly the production of fines resulting from exposure to a vibration environment.

b) Evaluate the effect of the clearance between the fuel sphere and the PICS (post-impact containment shell) on the integrity of the iridium PICS.

c) Evaluate the performance of the PISA vent after exposure to a vibration environment.

d) Time permitting, evaluate the effect of clearance between the PISA and the Graphite Impact Shell.

\subsection{Scope}

The fueled FSA fixture will be subjected to sinusoidal and random vibration in three orthogonal axes while in a simulated operational condition.

\subsection{Facilities and Equipment}

\subsection{Test Fire Facility}

3.1.1 Random Frequency Generator

3.1.2 XY Recorder 
3.2 Alpha Fuels Facility

3.2.1 M.B. Electronics

3.2.1.1 Shaker, Model C21

3.2.1.2 Exciter, Model 1025

3.2.1.3 Accelerometer, MB304

3.2.1.4 Liner Driver

3.2.1.5 Zero Drive Amplifier, N400

3.2.2 Vibration Readout Equipment

3.2.2.1 XY Recorder Input Selector, MB N-74

3.2.2.2 Log Convertor, Hewlett Packard, 7560 AM

3.2.2.3 XY Recorder, Hewlett Packard, 135

3.2.2.4 Oscilloscope, Tekronics

3.2.2.5 True RMS Voltmeter, Ballantine Lab M320

3.2.2.6 DC-AC Calibrator, Ballantine Lab M42lA

3.2.3 Functional Readout Equipment

3.2.3.1 Digital Voltmeter, Weston, 1240

3.2.3.2 Recorder, Bausch \& Lomb, Vom5

3.2.4 Miscellaneous Electrical Equipment

3.2.4.1 Volt-Ohm Meter, Simpson 260

3.2.5 Hand Tools

$\begin{array}{ll}3.2 \cdot 5 \cdot 1 & \text { Test Fixture Handling Gloves } \\ 3 \cdot 2 \cdot 5 \cdot 2 & \text { Torque Wrench } \\ 3 \cdot 2 \cdot 5 \cdot 3 \text { Allen Wrench Set } \\ 3.2 \cdot 5.4 \text { Slip Table Wrench Set } \\ 3.2 \cdot 5 \cdot 5 \text { Open End Wrench Set }\end{array}$

3.3 Hardware

The following hardware will be utilized:

- Vibration Test Fixture - Drawing SK-D-2380, Figure 1, designed and fabricated by MRC.

- $\mathrm{PuO}_{2}$ - Fueled PISA - S/N MHFT-1I.

- $\mathrm{ThO}_{2}$ - Simulated PISA - S/N MHT-3.

- Graphite Impact Shell - S/N 854134 (HITCO).

- Graphite Impact Shell - S/N Body 420 with Cap 415B (Sanders).

- Graphite Impact Shell - S/N Body 421 with Cap $416 \mathrm{~A}$ (Sanders). 


\subsection{Overall Instructions}

4.1 Handling

4.1.1 Lift the FSA fixture, using the handling gloves, properly held by the fins.

\subsection{Operating}

4.2.1 The rate of change in the fin root temperature should not exceed $33^{\circ} \mathrm{F}$ in $10 \mathrm{~min}$.

4.2.2 The PISA temperature should not exceed $2100^{\circ} \mathrm{F}$.

4.2.3 The fin root temperature should not exceed $360^{\circ} \mathrm{F}$.

4.2.4 Record data at approximately $20 \mathrm{~min}$ intervals during generator instability, and note in log any irregularities. When temperatures are stable, 1 -hr intervals are adequate.

4.2.5 The temperature is to be $1832^{\circ} \mathrm{F}-2100^{\circ} \mathrm{F}$ during testing.

4.3 Abort Conditions

4.3.1 A PISA temperature exceeding $2100^{\circ} \mathrm{F}$ may require termination of the test.

4.3.2 A sudden decrease in output power will terminate the test until adjustments are made.

4.4 Health Physics

4.4.1 Health Physics documents and/or requirements will be considered a part of this procedure.

4.4.2 In the event of a spill or health physics hazard, the test is terminated and the health physics supervisor will assume command of the operation, others will assist in any way possible.

4.4.2.1 Primary consideration will be given to reduce further hazard.

4.4.2.2 Secondary consideration will be given to reduce damage and waste of equipment.

\subsection{Pretest Procedure}

5.1 Open log.

5.2 Record date, time, and serial number of parts and test section generator. 
5.3 Make a general survey to determine that all facilities and equipment are ready to perform the required tests and that sufficient standards lab calibrations have been made to validate the tests.

5.4 Zero and calibrate the recorders used for temperature and power.

5.5 Accept the FSA fixture in hot hall behind the test cell.

5.6 Visually inspect fixture for good physical condition and make log notation.

5.7 Move fixture into cell and connect power and instrumentation.

5.8 Record data and note acceptable condition in log.

\subsection{Test Plan and Sequence}

6.1 Test 1 - Hot Thermal Checkout Bench Test (This is not a shake test)

This test uses simulated PISA $\mathrm{S} / \mathrm{N}$ MHT- 3 and graphite impact shell S/N Body 420 with Cap $415 \mathrm{~B}$.

- Heat-treat simulated $\left(\mathrm{ThO}_{2}\right)$ PISA $1 \mathrm{hr}$ at $1500^{\circ} \mathrm{C}$ according to specific instructions.

- Assemble simulated FSA in test fixture.

- Instrument PISA and fixture.

- Power up to $1832^{\circ} \mathrm{F}-2100^{\circ} \mathrm{F}$, as measured on the PISA, steady state.

- Record fixture and PISA temperatures after they reach steady state.

- Record power and temperature at several points as power is applied.

- Record temperature in accelerometer and shaker table mounting plate areas.

- Verify by post-test examination that preload and differential thermal expansion are acceptable.

6.2 Test 2 - Cold Dynamic Test

This test uses graphite impact shell S/N Body 421 with Cap 416A.

- Mount one accelerometer on fixture.

- Mount one accelerometer in metal simulated fuel core. 
- Assemble simulated FSA in test fixture according to specific instructions.

- Perform both the sine sweep and random vibration test on two axes; the excluded axis is either one of the two symmetrical axes.

- Perform a 1-G sine sweep from 20 to $2000 \mathrm{~Hz}$ in $3 \mathrm{~min}$.

- Perform the random vibration test spectrum, schedule A.

- Verify by post-test examination the cold dynamic structural integrity of the fixture.

6.3 Test 3 - Hot Safety Test with Simulated FSA

This test uses simulated $\left(\mathrm{ThO}_{2}\right)$ PISA S/N MHT-3 and graphite impact shell S/N Body 420 with Cap 4l5B (same as Test 1).

- Assemble simulated FSA in test fixture.

- Mount one accelerometer on fixture upper extremity.

- Mount one accelerometer on shaker mounting plate at bolt circle.

- Connect fixture and FSA thermocouples and instrument fixture external surface.

- Attain steady state FSA temperature of $1832^{\circ} \mathrm{F}-2100^{\circ} \mathrm{F}$.

- Perform a l-G sine sweep similar to Test 2 on the same two axes.

- Perform the random vibration test spectrum, Schedule A, similar to Test 2 on the same two axes.

- Monitor thermocouples and heater power.

- Verify by post-test examination adequacy of fixture assembly.

- Retain assembled simulated FSA intact for future GE evaluation.

6.4 Test 4 - Fueled FSA Dynamic Test

This test uses $\mathrm{PuO}_{2}$ fueled PISA S/N MHFT-11 and graphite impact shell S/N 854134 .

- Heat-treat PISA $18 \mathrm{hr}$ at $1500^{\circ} \mathrm{C}$, according to specific directions.

- Open fueled PISA burst disk.

- Assemble fueled FSA.

- Assemble FSA in test fixture. 
- Mount one accelerometer on fixture upper extremity similar to Test 3 .

- Mount one accelerometer on shaker mounting plate similar to Test 3.

- Connect fixture thermocouples.

- Attain steady state FSA temperature of $1832^{\circ} \mathrm{F}-2100^{\circ} \mathrm{F}$.

- Perform the random vibration test spectrum, Schedule B, on $\mathrm{x}$ axis; and record response.

- Radiograph PISA, while in the fixture, through the PISA poles and at two points $90^{\circ}$ apart through the equator.

- Attain required steady state temperature; perform the random vibration test, Schedule $B$, on $y$ axis; and record response.

- Radiograph PISA, while in the fixture, through the PISA poles and at two points $90^{\circ}$ apart through the equator.

- Attain required steady state temperature; perform the random vibration test, Schedule $B$, on the $z$ axis; and record response.

\subsection{Post-Test Procedure}

7.1 Remove the FSA fixture from the vibration equipment.

7.2 Record in the log the results of a complete physical condition inspection.

7.3 Close out log, making comment as required.

Post-Test Evaluation - Phase 1:

Performed at MRC:

- Remove FSA from fixture.

- Drill out FSA lock pin.

- Remove PISA from FSA.

- Swipe components for fuel release.

- Visually inspect components.

- Radiograph PISA through the poles and at two points $90^{\circ}$ apart through the equator.

- Test PISA for helium leak.

- Reassemble PISA in FSA (using new lock pin). 
- Ship fueled FSA intact ( $\mathrm{PuO}_{2}$ fueled PISA S/N MHFT-7 and Graphite Impact Shell S/N 854134) to LASL for posttest evaluation - Phase 2.

- Provide to GE for further independent evaluation the following hardware:

- Simulated FSA intact $\left(\mathrm{ThO}_{2}\right.$ PISA S/N MHT-3 and Graphite Impact Shell S/N Body 420 with Cap 415B).

- Graphite Impact Shell - S/N Body 421 with Cap 416A.

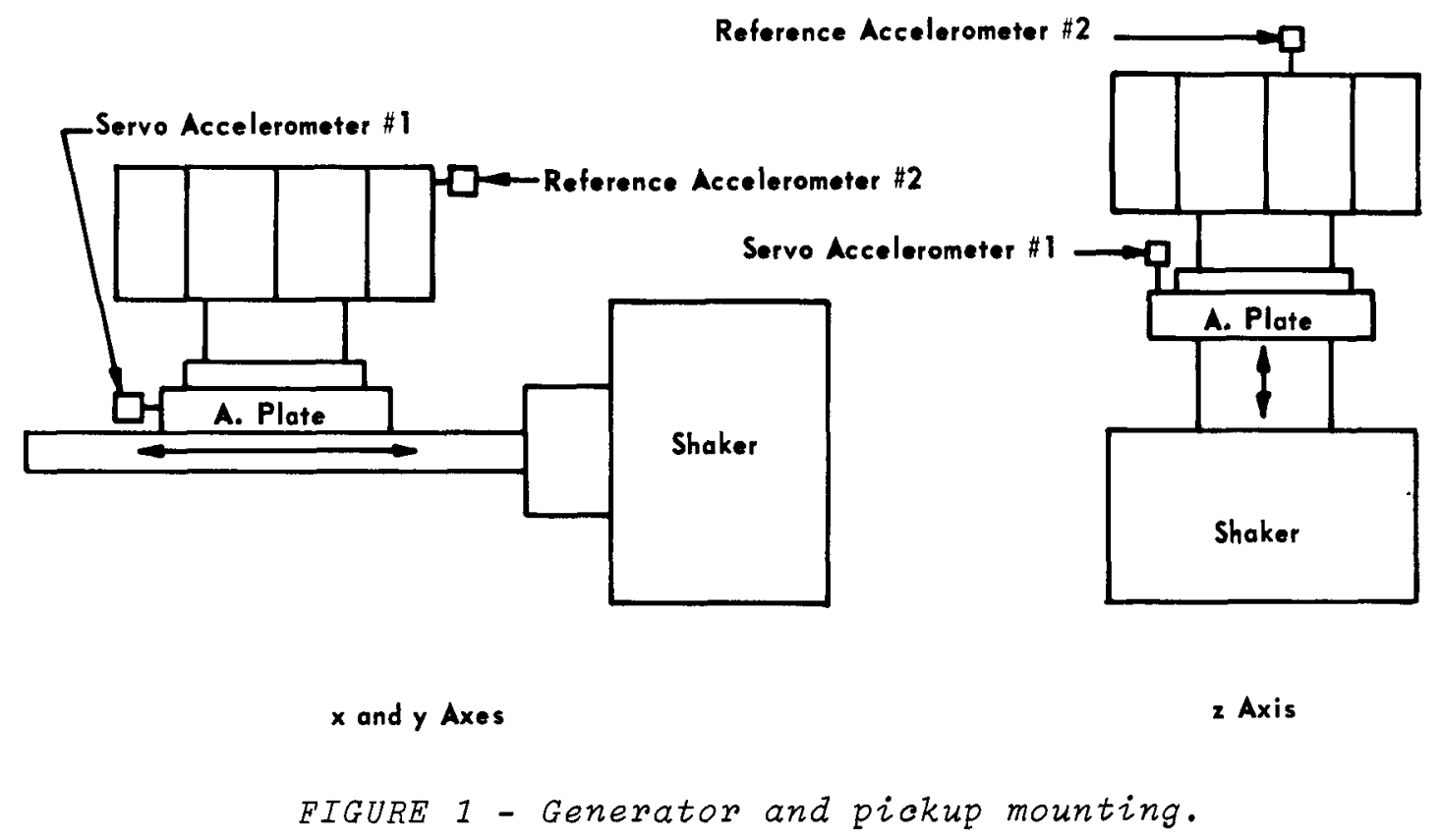


Blank page 


\section{ATTACHMENT A \\ 2. HEALTH PHYSICS PROCEDURE FOR THE VIBRATION TEST OF THE PIONEER SOURCE}

\section{Objective}

The purpose of this procedure is to ensure good health physics precautions are used during the vibration test of the Pioneer source and Generator.

I. The building will be checked out by a health physics surveyor before the source is removed from the universal shipping container.

A) The air sample pump will be started and new air samples will be installed.

1) The time the air samples are changed will be recorded.

2) The changed air samples will be counted by the SM counting room for background reference.

B) The stack monitors will be checked out to ensure they are in operating condition.

1) New filter media will be installed.

2) The instruments will be set on the Xl scale, alarm at 50 counts/min, and the air flow at 40 liters $/ \mathrm{min}$.

C) The air monitors in the building will be checked with a source and set to operating levels.

II. Cell 107 shall be prepared by the following:

A) Five to ten general wipes shall be taken throughout the cell to check for levels of contamination.

B) A plastic sheet shall be installed over the entrance to the cell to act as a contamination control barrier between the cell and the cell main door and operating Corridor 114 .

C) Film badges shall be worn at all times by the operating personnel, and personnel working with the source will be issued wrist badges. 
D) Work shall be done in two-piece whites, safety shoes, and respirators (worn either in use or around the neck).

E) The operating corridors will be treated as a yellow control zone.

III. The source will be monitored for unloading inside the cell.

A) Gamma-neutron readings shall be taken on the generator at approximately those distances where personnel will be working.

B) Wipes shall be taken on the generator to check for alpha contamination which may be present from a possible ruptured capsule.

C) If no high levels of contamination are present, the capsule will be permitted to be prepared for the test. When the preparation of the capsule is completed, the personnel in the cell shall be checked for contamination upon their clothes and person before leaving the cell. After checkout, personnel shall leave the cell by the hole in the plastic barrier, and the plastic barrier shall be sealed and the cell main door shut.

IV. Before and during the test, health physics shall monitor the outside operating corridors by:

A) Performing gamma-neutron surveys at the cell window and walls.

B) Checking air samples in the corridors.

C) Observing the air monitor inside the cell to notice any increase in the meter or the alarming of the monitor by the flashing of the red visual alarm if a release has occurred.

D) Checking the air monitors in the corridors for increases on the meters and possible alarming.

E) Taking spot wipes in the corridors to check contamination levels.

V. Upon reentry into the cell, the cell main door shall be opened and the plastic barrier shall be wiped on the outside to check for alpha contamination. The plastic barrier shall then be cut and wipes shall be taken on the inside of the plastic to check for contamination. If no, or low level, contamination is present, operating personnel shall be allowed to enter the cell for preparation of the capsule. General wipes shall be taken on the inside of the cell for contamination checks.

Exiting from the cell shall be in the same manner as prescribed in III. 
VI. If, during the preparation or testing of the source, the source should accidently rupture, appropriate health physics actions shall be taken to protect all operating personnel from high levels of contamination, and the spread of contamination from the cell.

VII. After the tests are completed on the source:

A) All air samples shall be collected and counted.

B) Wipe surveys shall be taken of cell 107, the operating corridors and of all areas in the yellow control zone.

C) Records will be gathered and a report issued on the health physics aspects of the test.

VIII. The source will be loaded into the shipping cask at the completion of the test. The health physics surveyor will take the necessary surveys to return the source into the shipping cask. 
Blank page 
ATTACHMENT B

MHW TEST RUN SUMMARV SHEET

\begin{tabular}{|c|c|c|c|c|}
\hline TEST 非 & NAME & RUN 非 & PURPOSE & REMARKS \\
\hline 1 & Bench Test & -- & $\begin{array}{l}\text { To validate vibration } \\
\text { fixture temperature } \\
\text { and structure capabilities. }\end{array}$ & $\begin{array}{l}\text { After several runs Kanthal D } \\
(0.020) \text { wire was final choice. } \\
\text { Expansion was not a problem. } \\
\text { See Temperature vs. Input Power } \\
\text { Plot. }\end{array}$ \\
\hline 2 & Dynamic & $1-8$ & $\begin{array}{l}\text { To validate vibration } \\
\text { fixture dynamic strength } \\
\text { capability and dynamic } \\
\text { transfer functions. }\end{array}$ & $\begin{array}{l}\text { No tape cal signal on tape. } \\
\text { Random Schedule } A_{\text {. }}\end{array}$ \\
\hline 3 & $\begin{array}{l}\text { Electric } \\
\text { Heater Hot } \\
\text { Safety } \\
\text { Test }\end{array}$ & $9-10$ & $\begin{array}{l}\text { To validate fixture } \\
\text { safety and heater } \\
\text { capability. }\end{array}$ & $\begin{array}{l}\text { (1) Tape Ca1. on tape but not } \\
\text { satisfactory to GE. Heater } \\
\text { burned out during run-- did } \\
\text { not affect test. Heater wire } \\
\text { was changed to Kanthal A-1 } \\
(0.051) \text { and potted in with } \\
\text { Dylon-C cement. } \\
\text { (2) Random Schedule A. }\end{array}$ \\
\hline
\end{tabular}

(1) $\mathrm{GE}$ wanted this test run while previous tapes were analyzed.

${ }^{(2)} \mathrm{GE}$ wanted to re-run dynamic tests immediately. 
MHW TEST RUN SUMMARY SHEET (Continued)

\begin{tabular}{|c|c|c|c|c|}
\hline TEST 非 & NAME & RUN 非 & PURPOSE & REMARKS \\
\hline 2 & Dynamic & $11-19$ & $\begin{array}{l}\text { Re-run of Dynamic runs using } \\
\text { F。S. Tape Ca1。\& Added } \\
\text { Accelerometer Data After } \\
\text { Run 13. }\end{array}$ & $\begin{array}{l}\text { Runs OK Per GE. } \\
\text { Random Schedule A }\end{array}$ \\
\hline 3 & $\begin{array}{r}\text { Hot Safety } \\
\text { and Elec. Heat }\end{array}$ & $20-21$ & $\begin{array}{l}\text { Re-run of Safety and } \\
\text { Electric Heater Tests }\end{array}$ & $\begin{array}{l}\text { Runs OK. } \\
\text { Random Schedule A }\end{array}$ \\
\hline 4 & $\begin{array}{l}\text { Real Fuel } \\
\text { Test }\end{array}$ & $22-27$ & $\begin{array}{l}\text { LES } 8 / 9 \text { Test on Fueled } \\
\text { Capsule }\end{array}$ & $\begin{array}{l}\text { Runs } \mathrm{OK} \\
\text { Random Schedule B }\end{array}$ \\
\hline 2 & Dynamic & $28 A-51 A$ & $\begin{array}{l}\text { Post Fueled Test } \\
\text { Dynamic Test }\end{array}$ & $\begin{array}{l}\text { More data desired by GE after } \\
\text { above tests } \\
\text { Random Schedule C. }\end{array}$ \\
\hline 4 & $\begin{array}{l}\text { Safety } \\
\text { Sequential }\end{array}$ & $52-58$ & $\begin{array}{l}\text { Launch Power Phase } \\
\text { Vibration Input to } \\
\text { FSA }\end{array}$ & $\begin{array}{l}\text { Runs OK. } \\
\text { Random Schedule C }\end{array}$ \\
\hline
\end{tabular}


ATTACHMENT C

RANDOM VIBRATION SCHEDULES

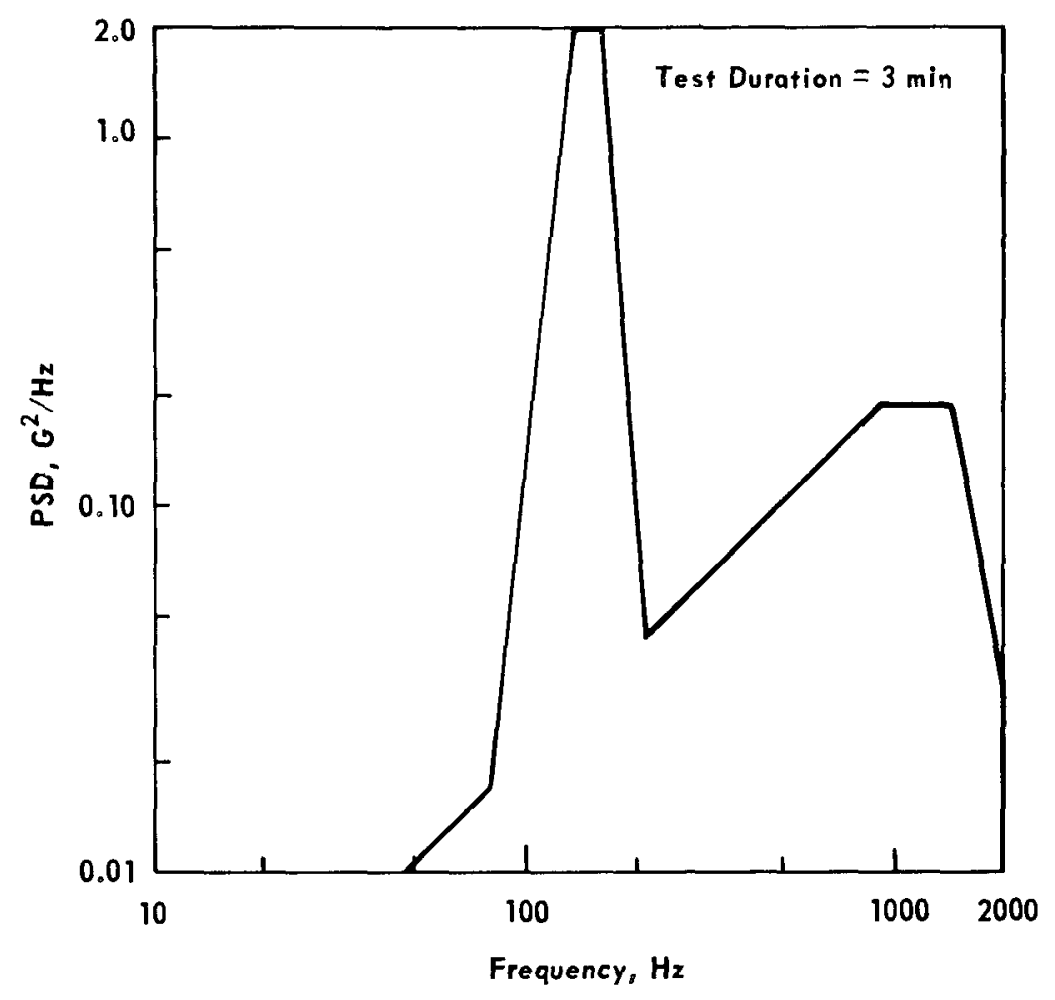

FIGURE 2 - Random vibration test scheduze $A$. 


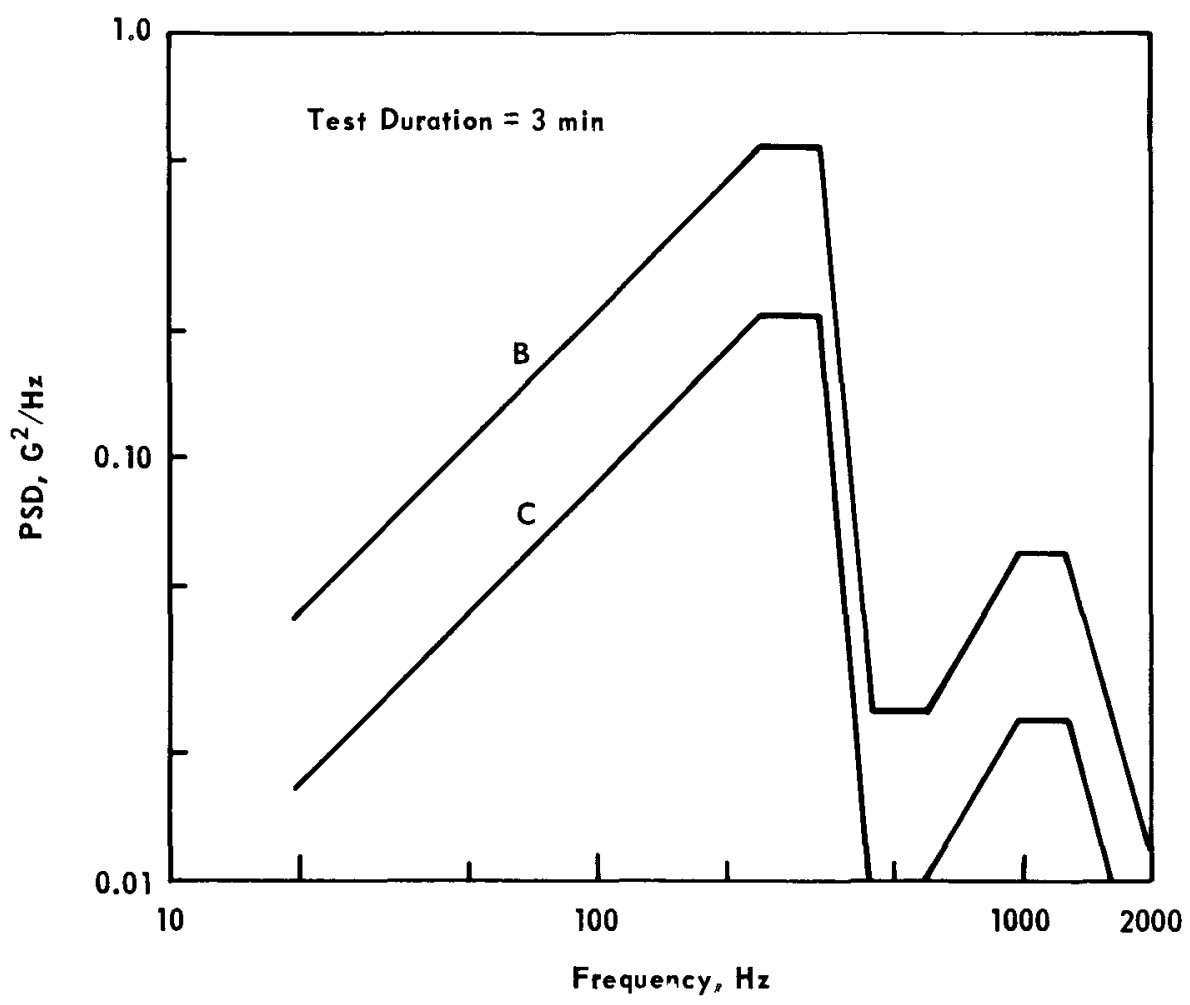

FIGURE 3 - Random vibration test schedule $B$ \& $C$.

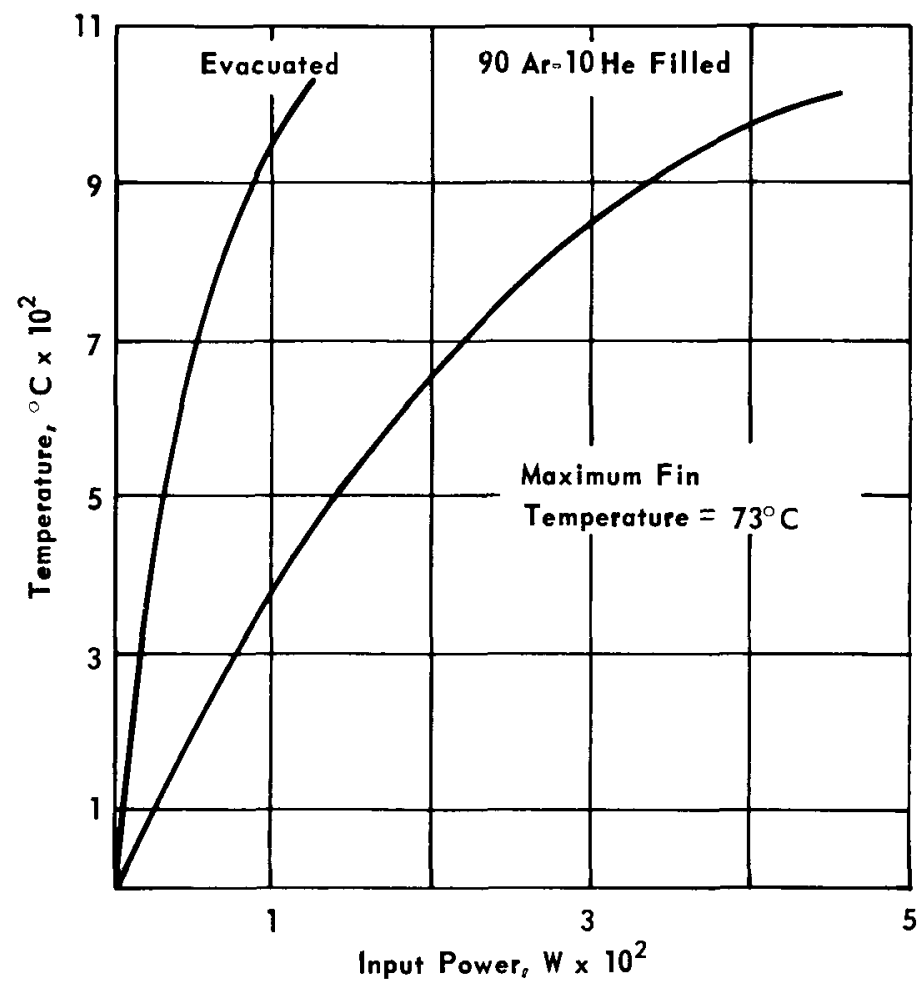

FIGURE 4 - MHW Test \#1. 
ATTACHMENT D

\section{VIBRATION DATA SHEET}

\begin{tabular}{|c|c|c|c|c|c|}
\hline DATE & $9 / 26 / 72$ & TEST PIECE & Dynamic & VIBRATION & SCHEDULE Sine \\
\hline RUN 非 & 1 & SERIAL 非 & -- & EQUIPMENT & $\mathrm{MB}$ \\
\hline
\end{tabular}

\begin{tabular}{|c|c|c|c|c|c|}
\hline \multirow{2}{*}{ ACCELEROMETER } & \multicolumn{2}{|c|}{ FULL SCALE } & \multirow{2}{*}{$\begin{array}{l}\text { RECORDER } \\
\text { CHANNEL }\end{array}$} & \multirow{2}{*}{ ACCEL. LOCATION } & \multirow{2}{*}{ REMARKS } \\
\hline & Volts & $G^{\prime} s$ & & & \\
\hline 1 & & & & MTG Plate & Servo \\
\hline 2 & & & 4 & Metal Ball & $\begin{array}{l}300 \text { grams simulated } \\
\text { fuel ball }\end{array}$ \\
\hline 3 & & & 5 & Graph - Same Axis & \\
\hline 4 & & & 6 & Graph - Off Axis & \\
\hline
\end{tabular}




\section{VIBRATION DATA SHEET}

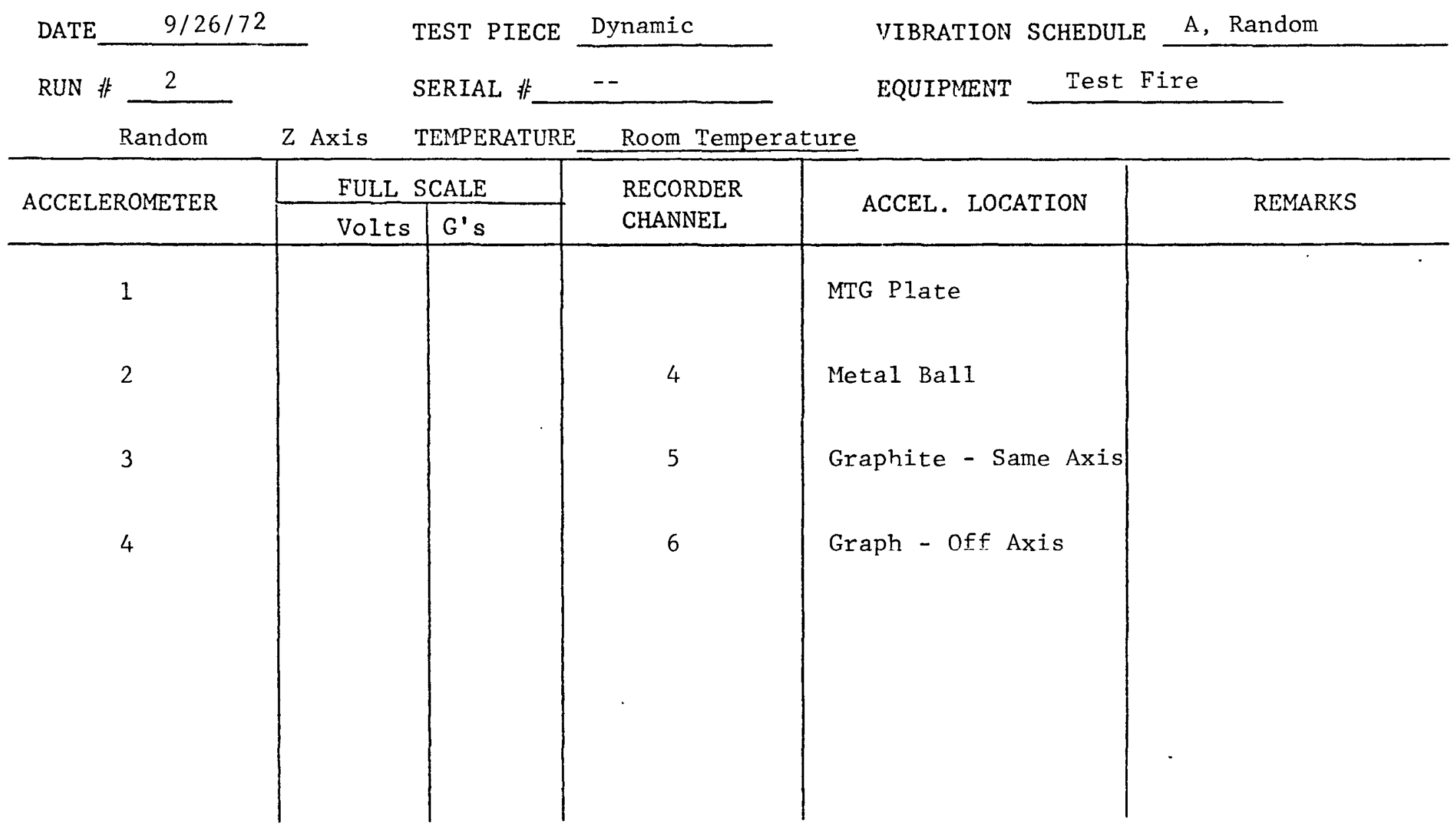




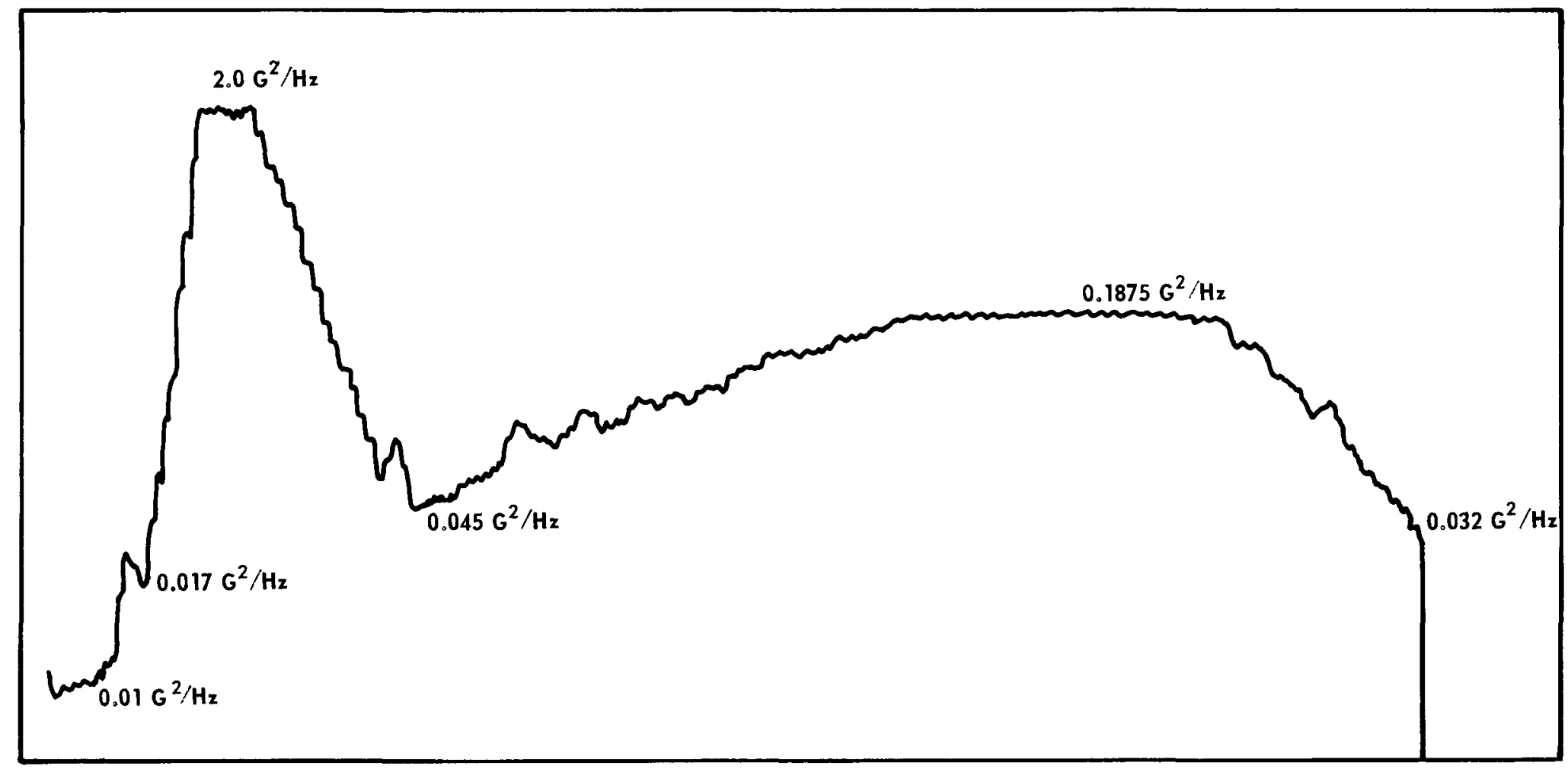

FIGURE 5 - Test \#2, Run \#2 (Sept. 26, 1972). 
VIBRATION DATA SHEET

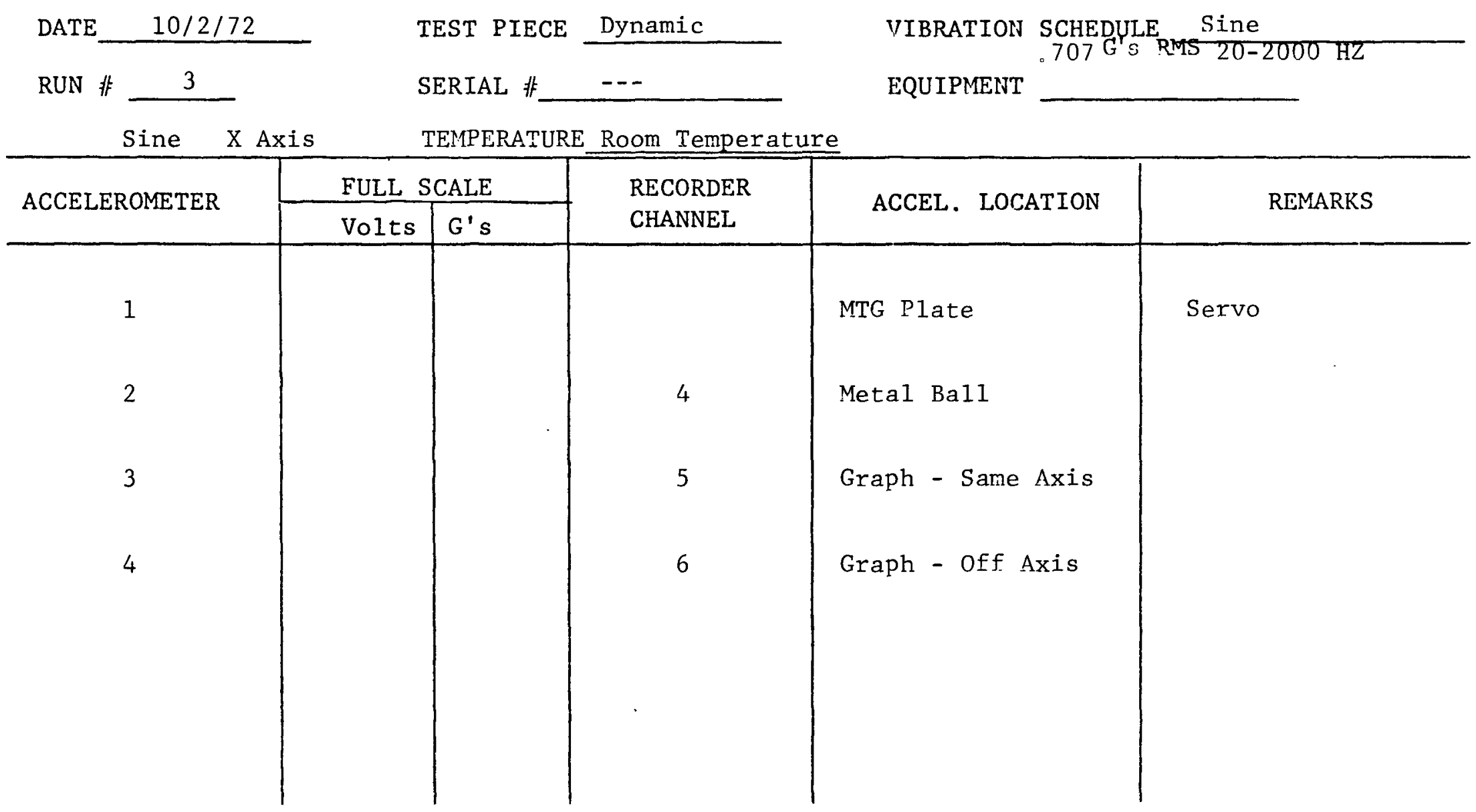




\section{VIBRATION DATA SHEET}

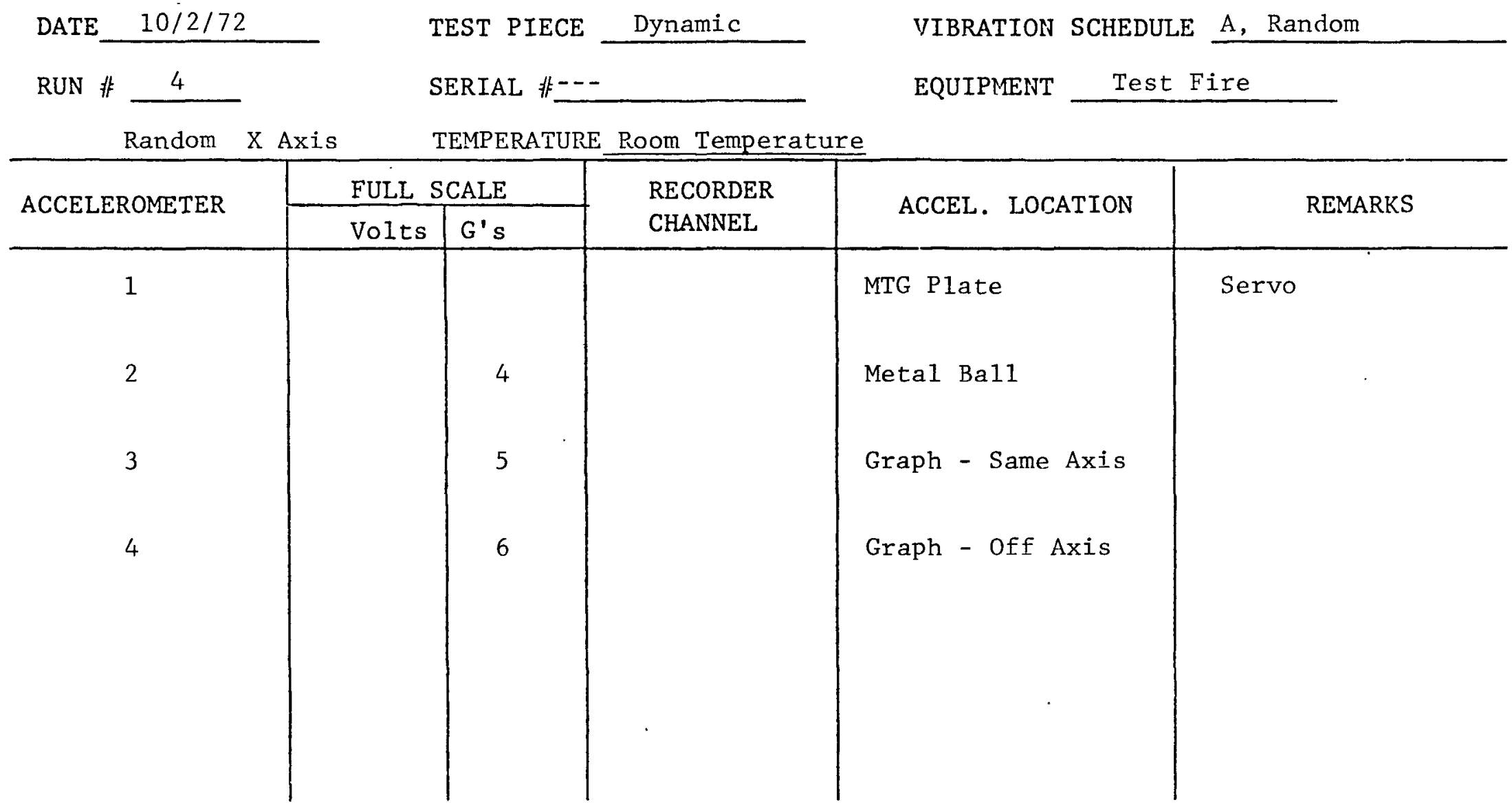




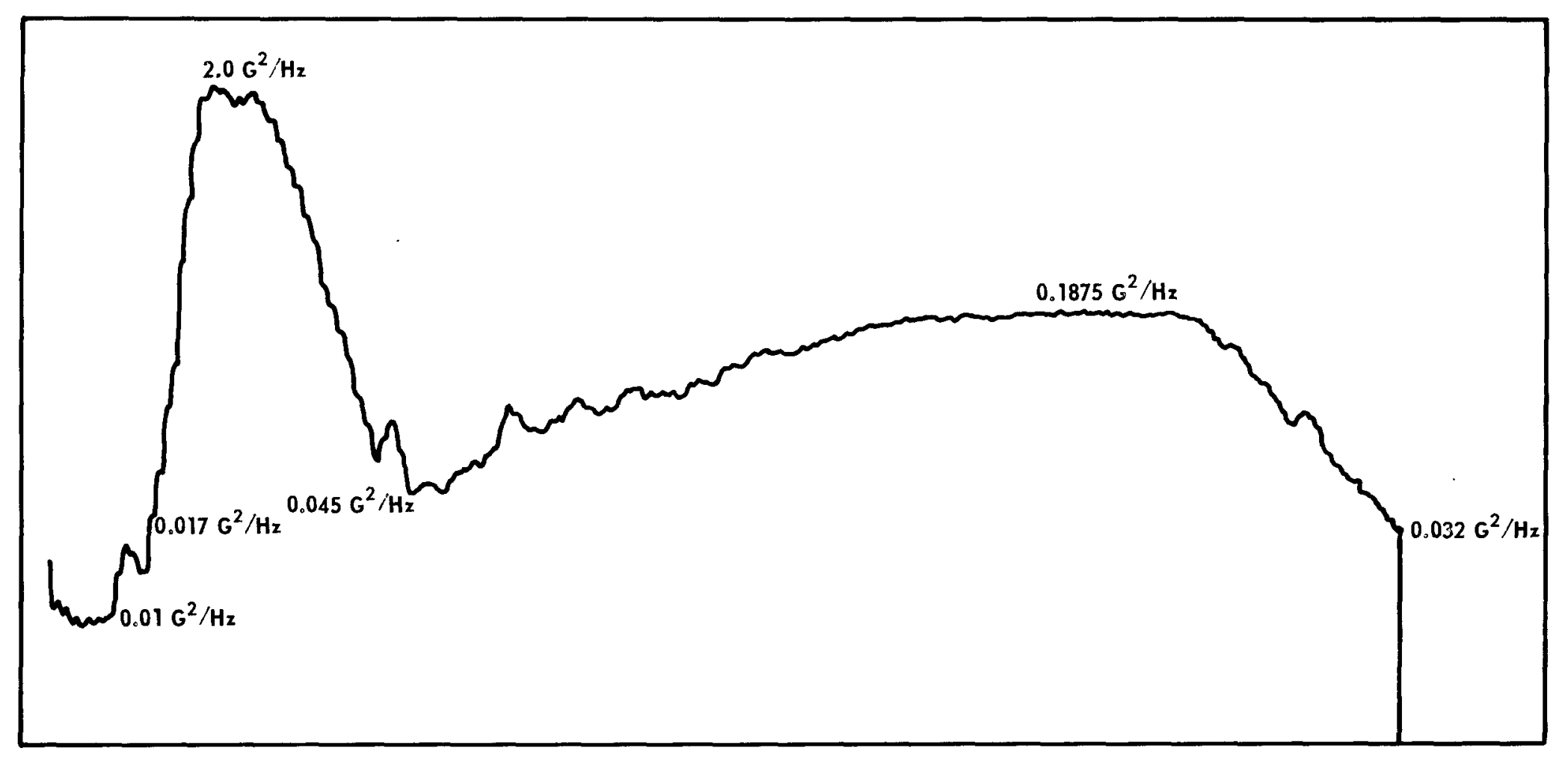

FIGURE 6 - Teșt\#2, Run\#4 (oct. 2, 1972). 


\section{VIBRATION DATA SHEET}

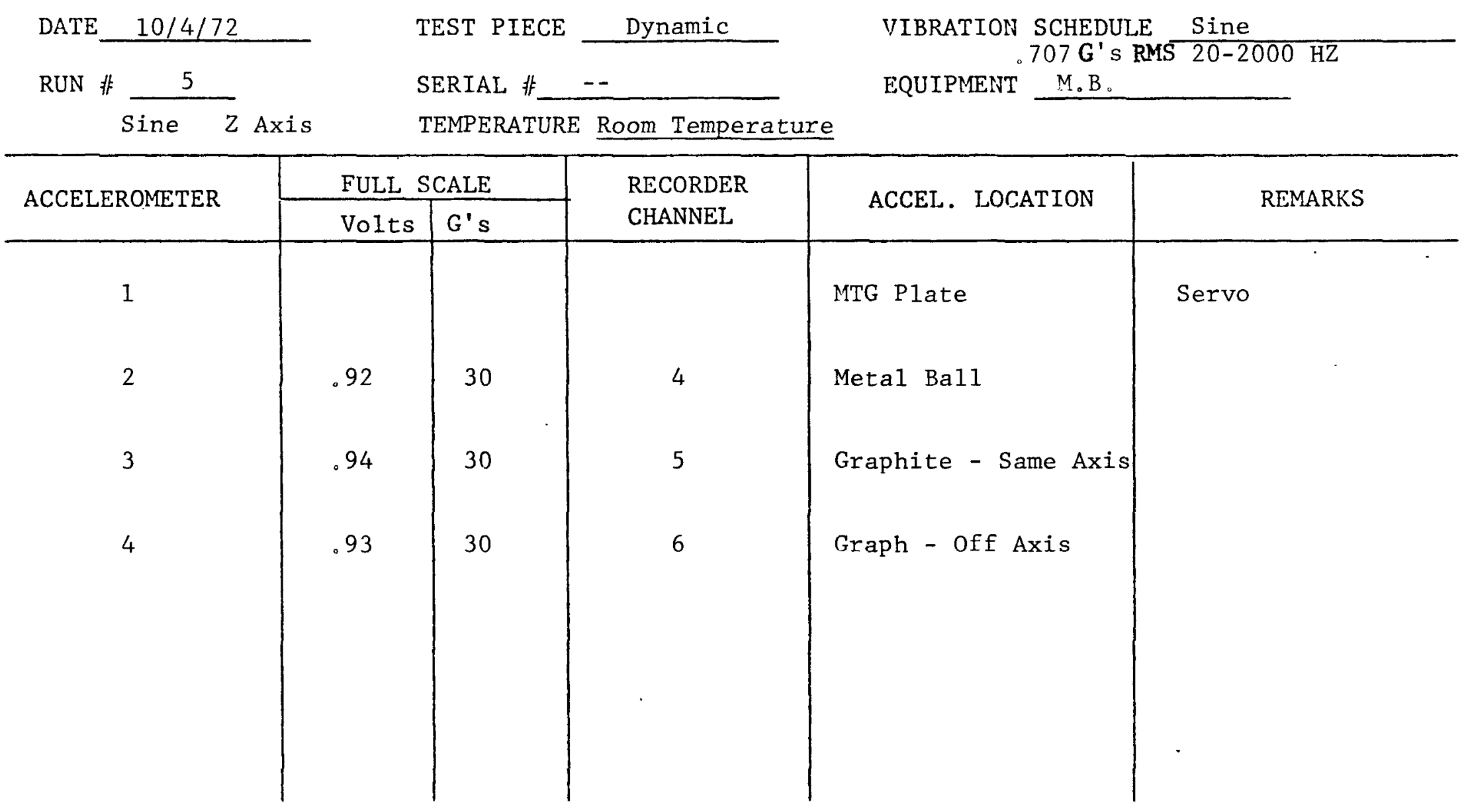




\section{VIBRATION DATA SHEET}

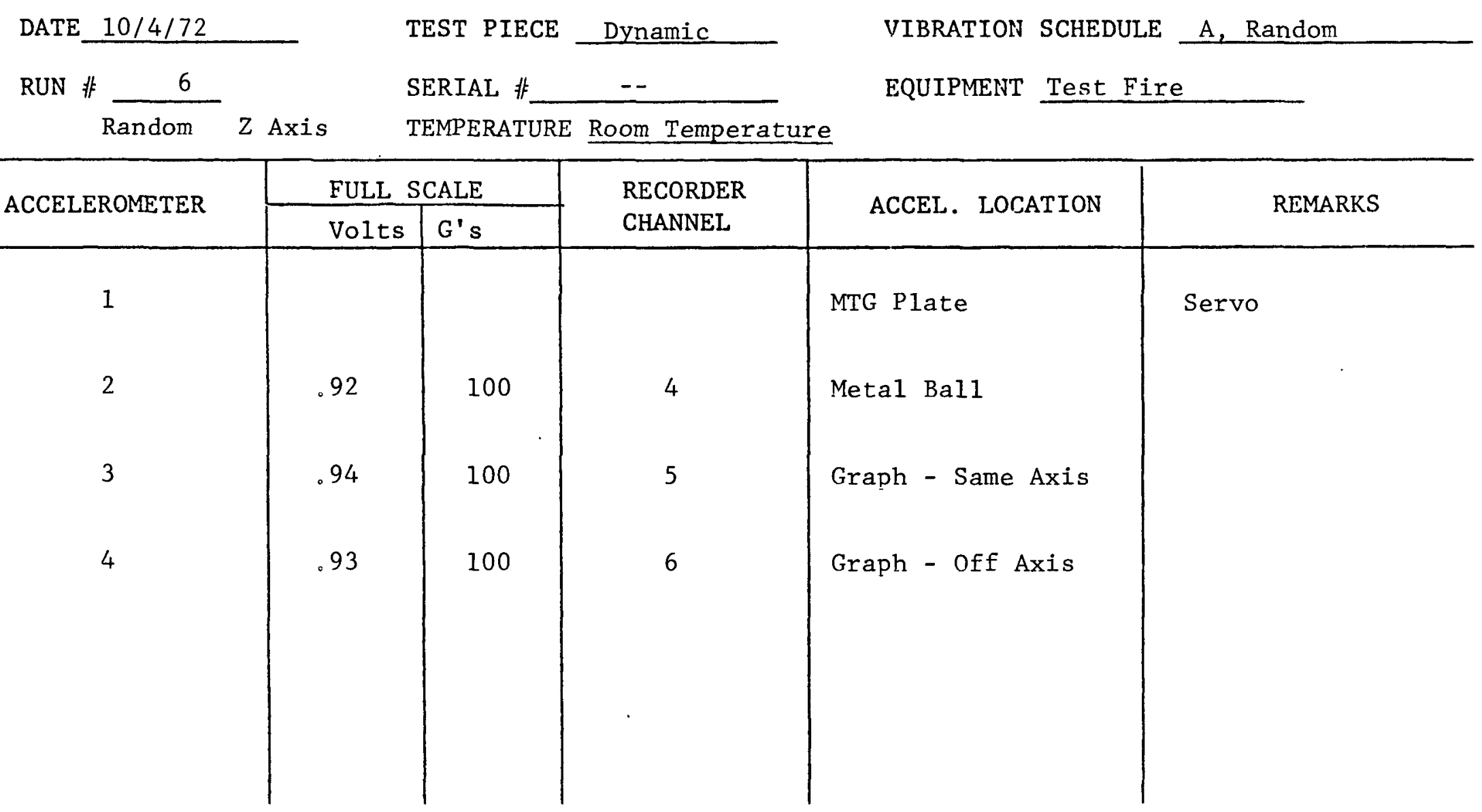




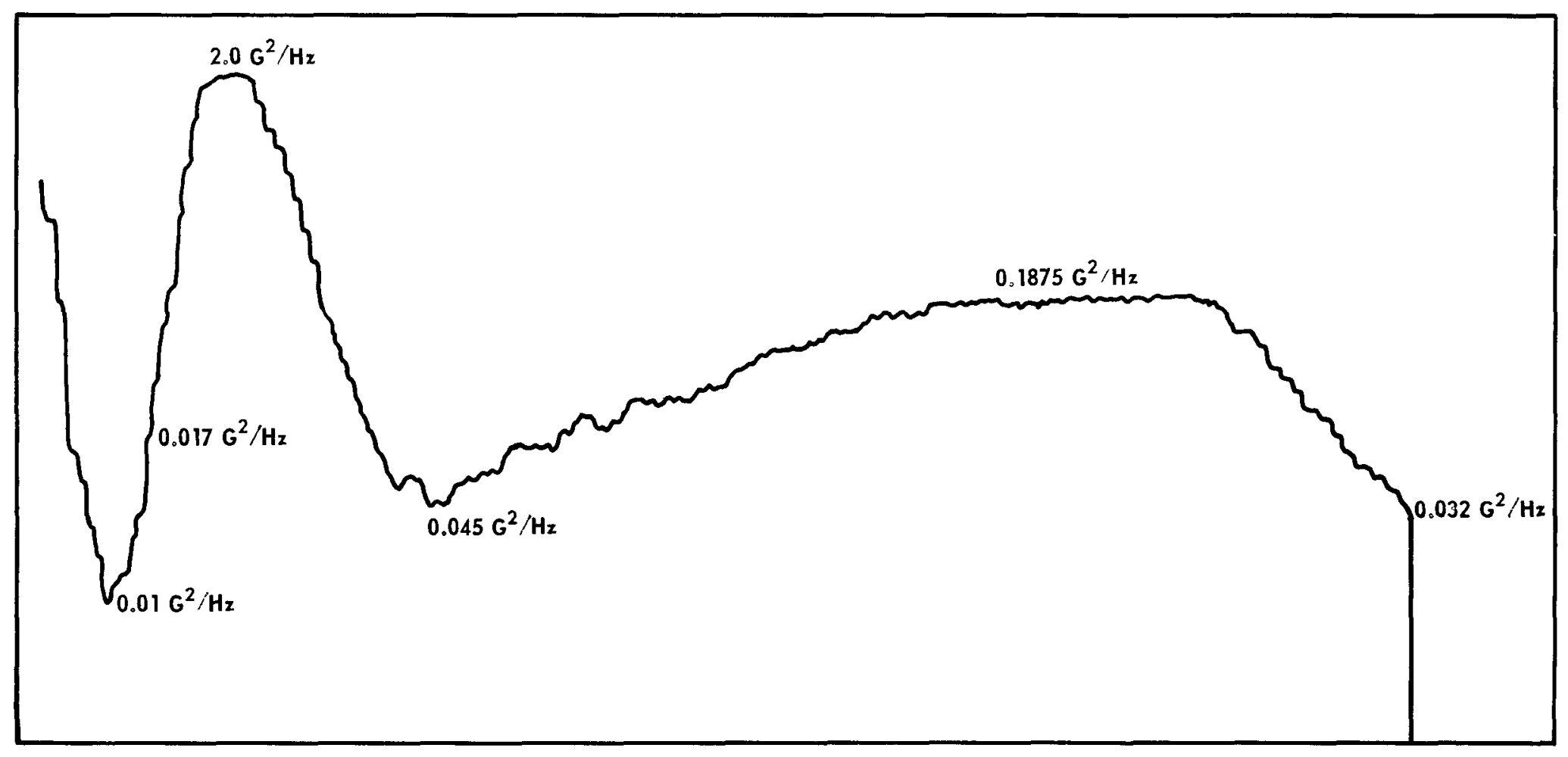

FIGURE 7 - Test \#2, Run \#6 (oct. 4, 1972). 
VIBRATION DATA SHEET

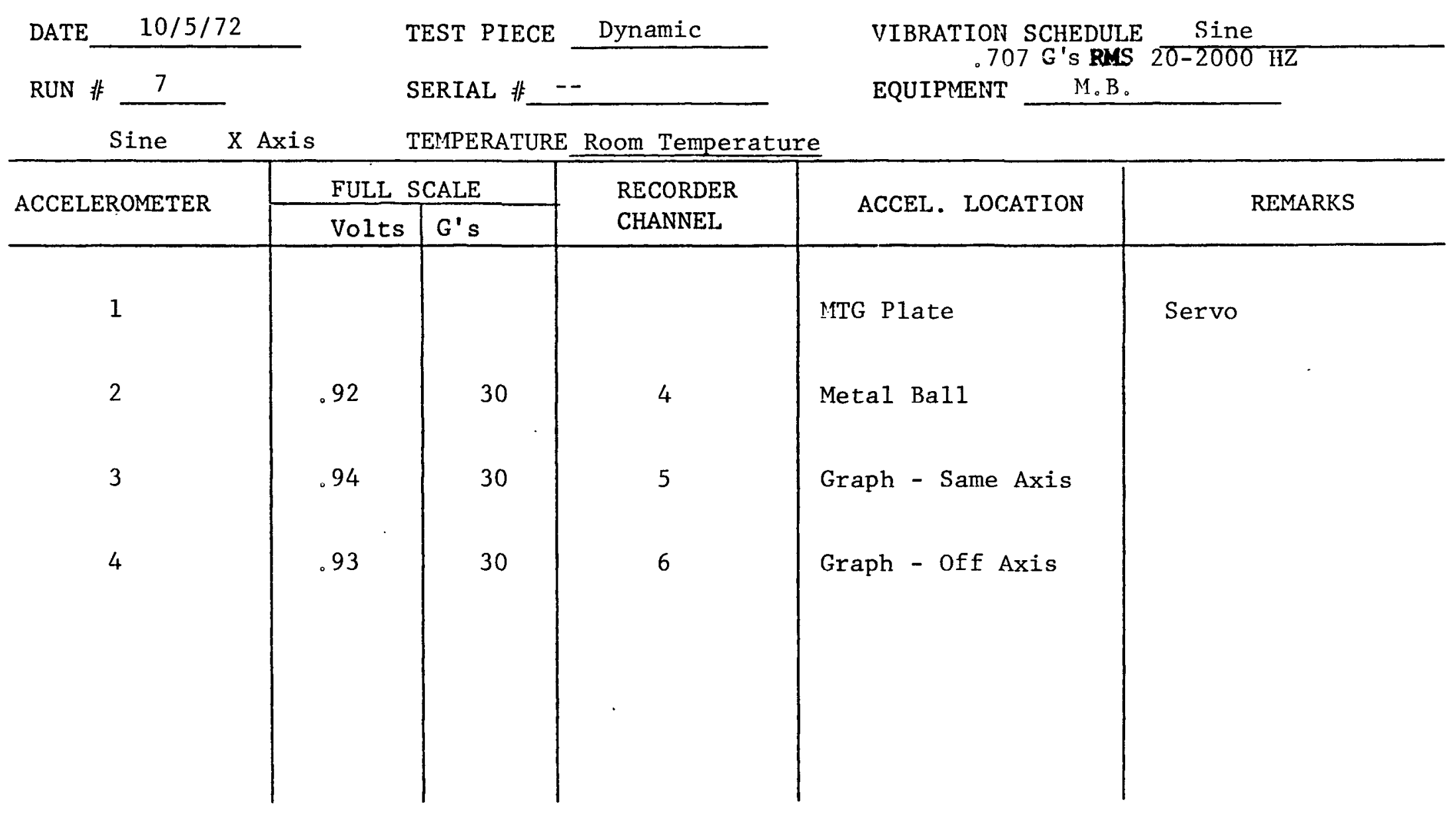




\section{VIBRATION DATA SHEET}

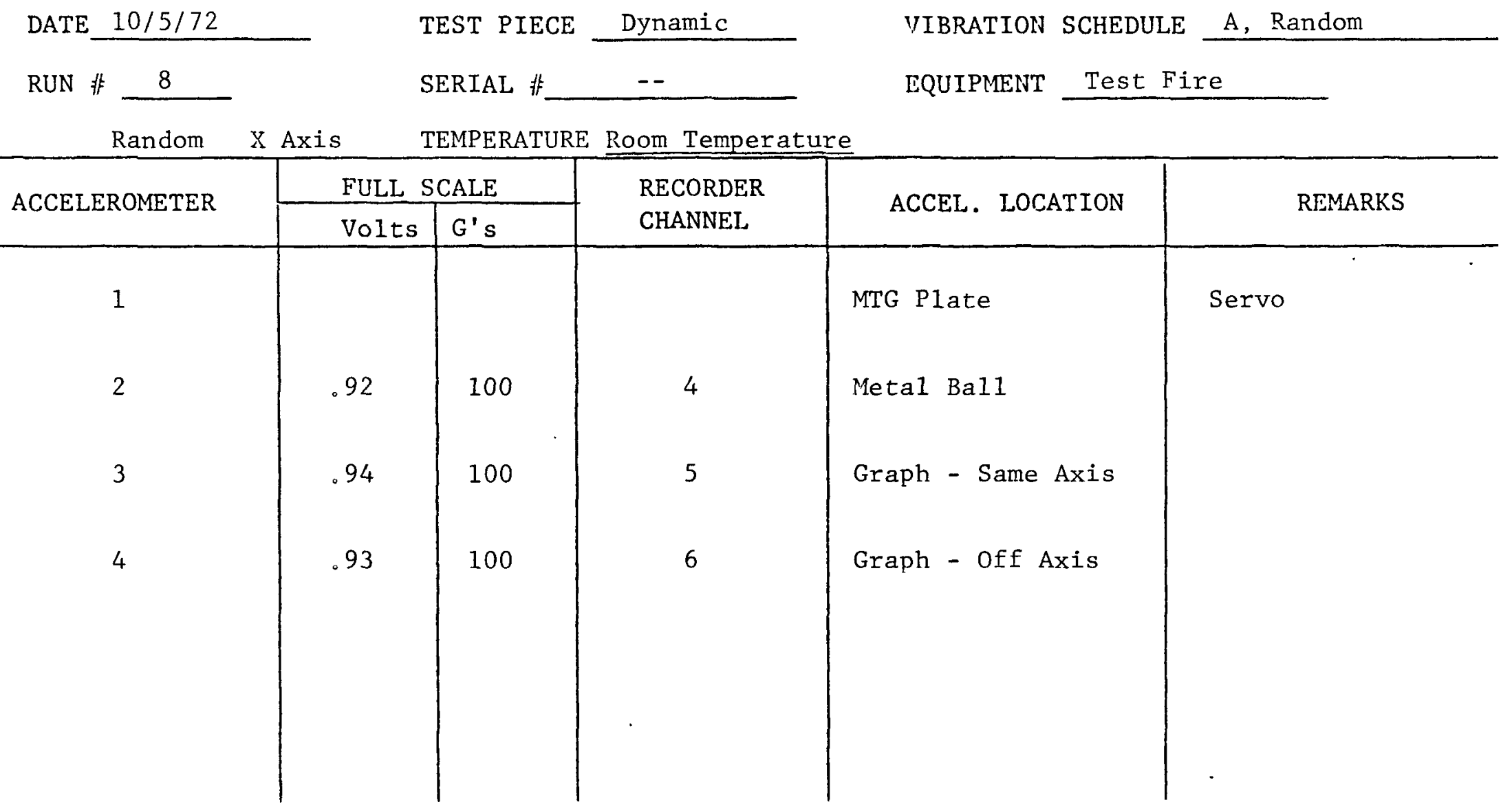




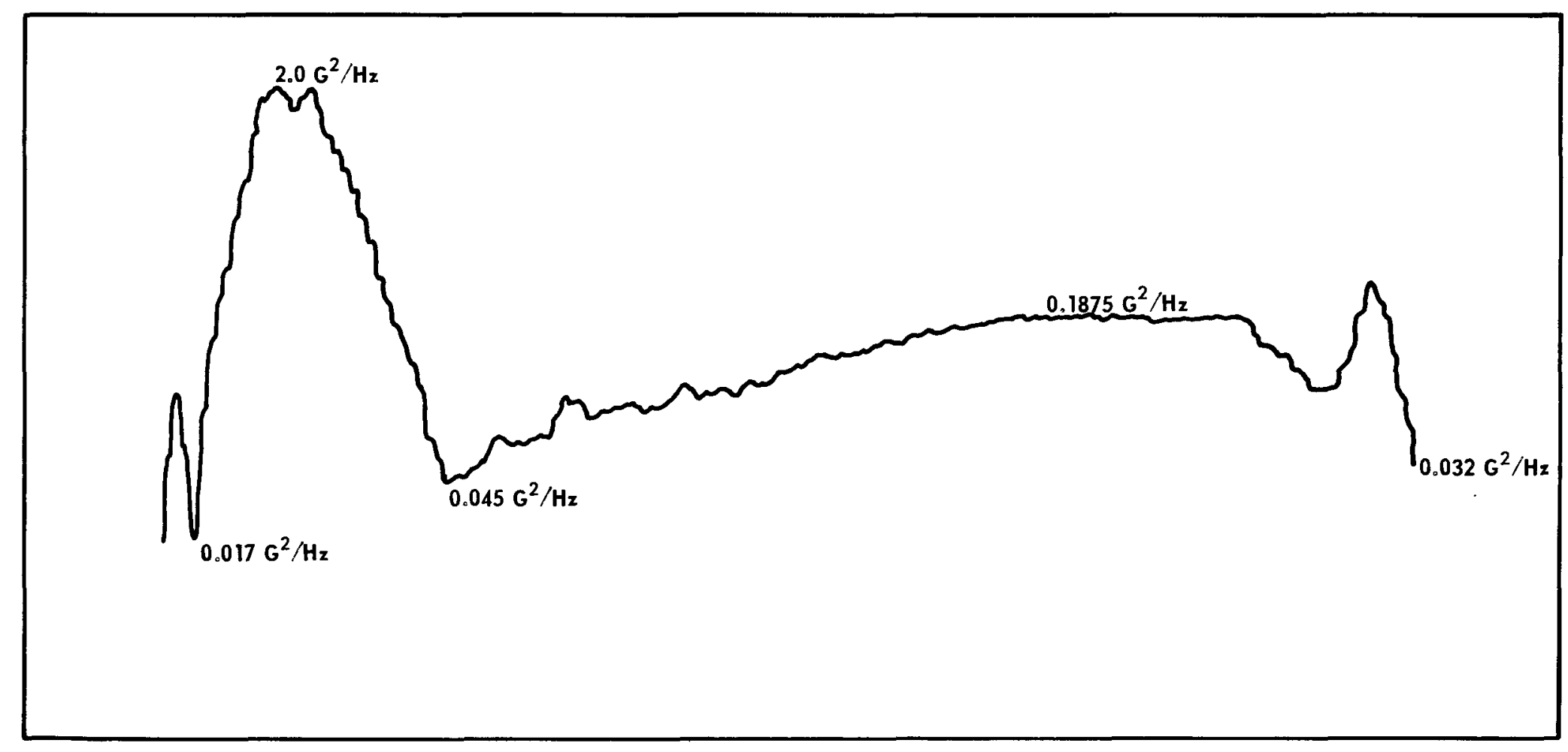

FIGURE 8 - Test \#2, Run \#8 (Oct. 5, 1972). 


\section{VIBRATION DATA SHEET}

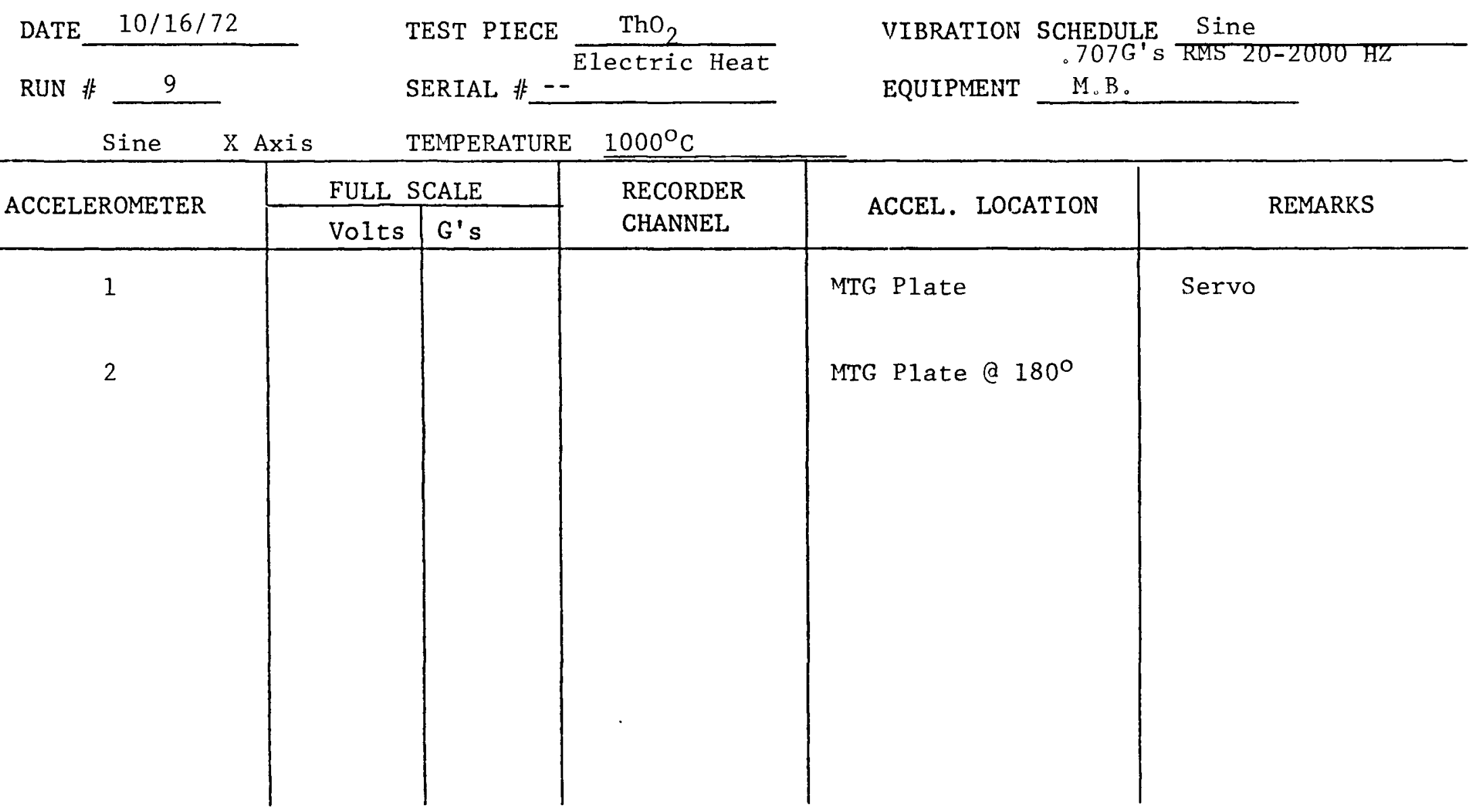




\section{VIBRATION DATA SHEET}

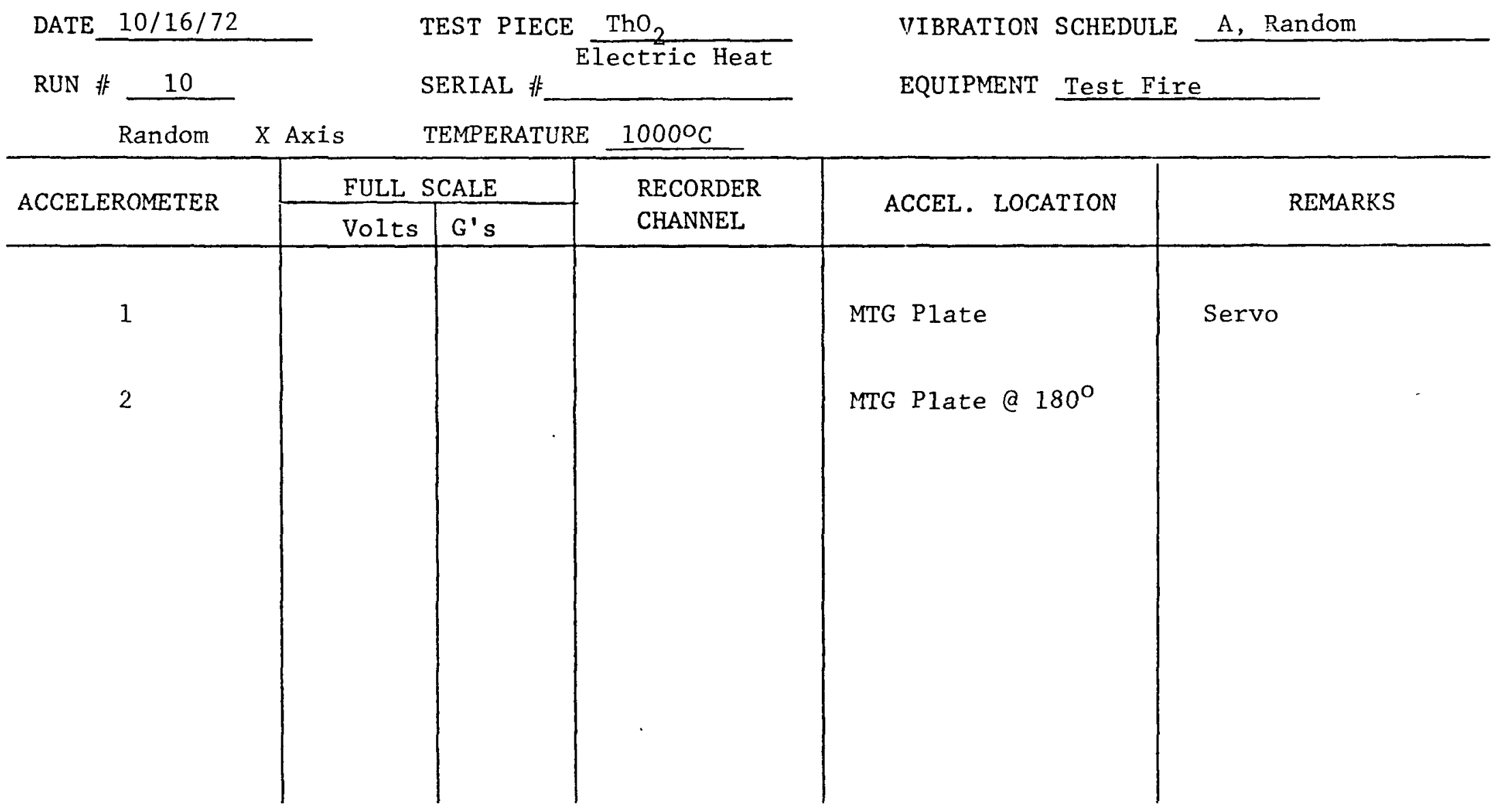




\section{VIBRATION DATA SHEET}

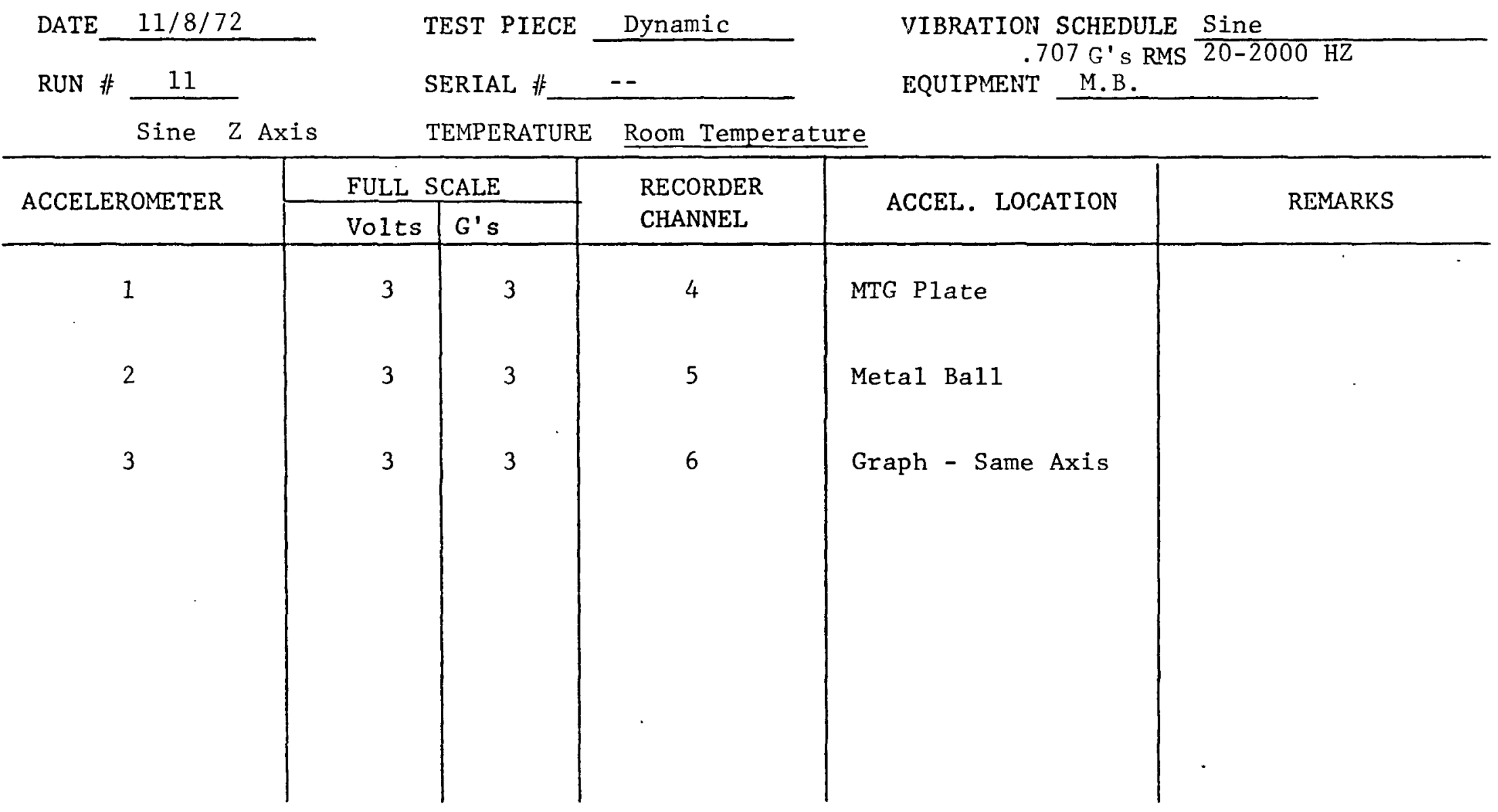




\section{VIBRATION DATA SHEET}

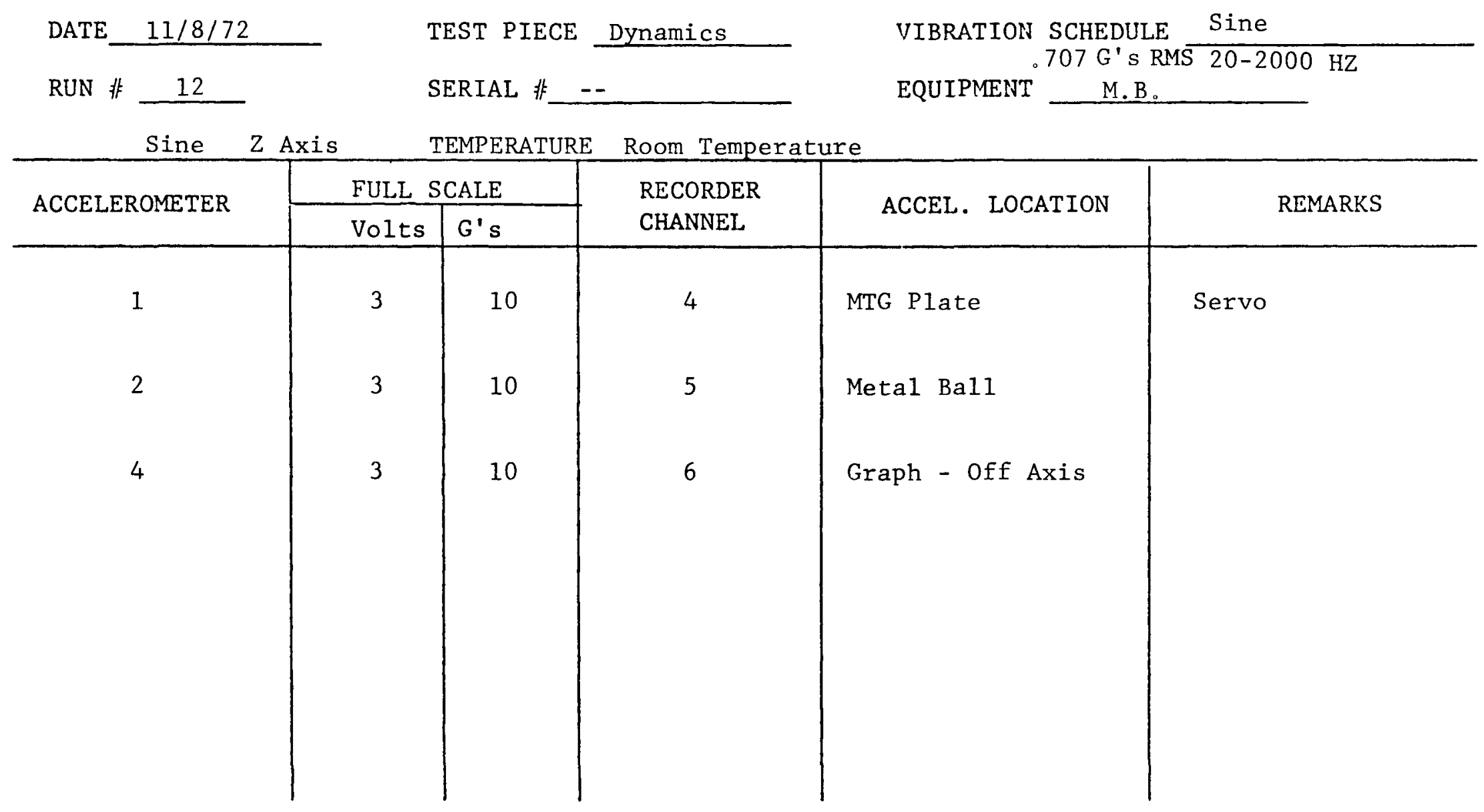




\section{VIBRATION DATA SHEET}

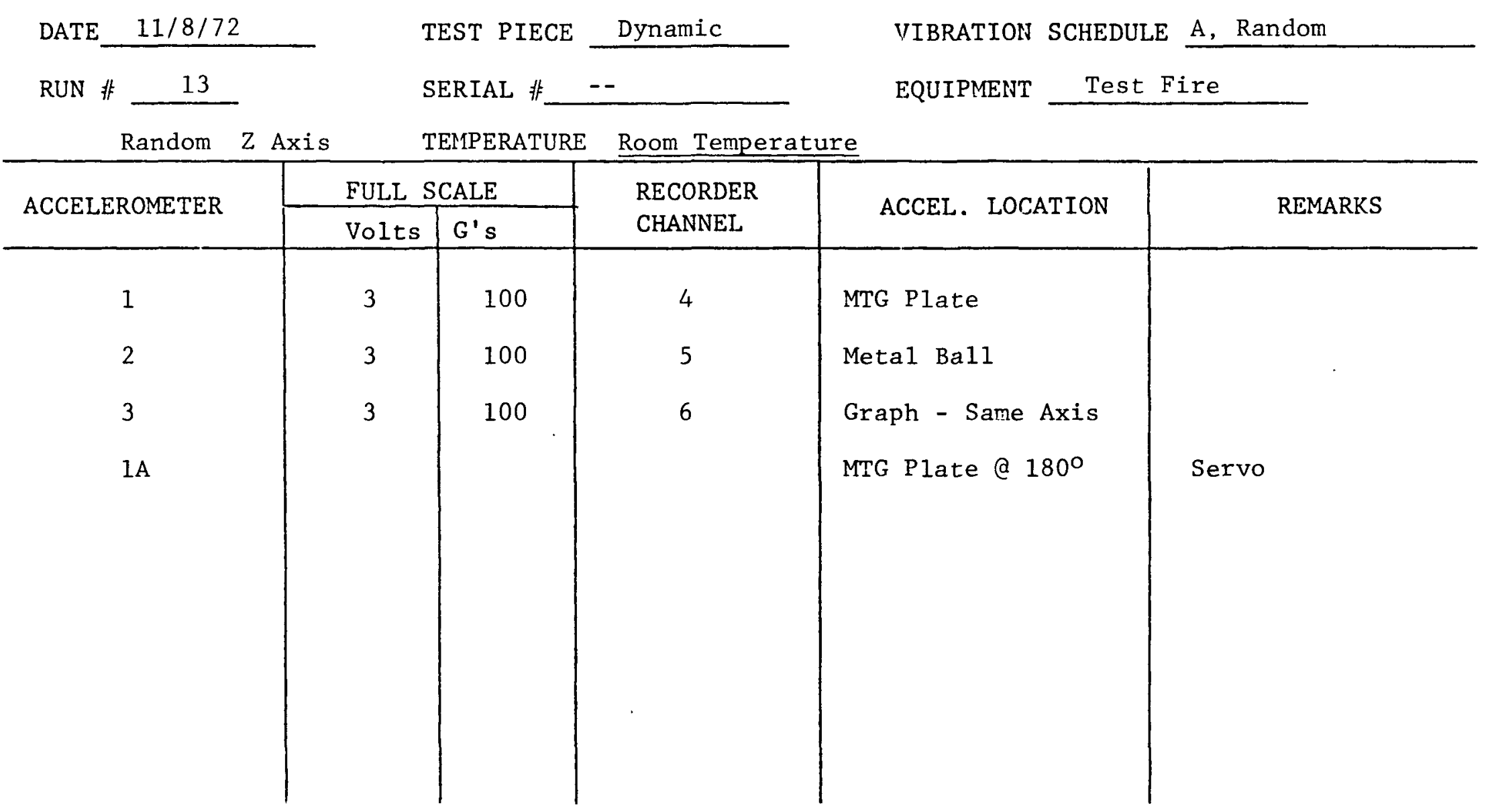




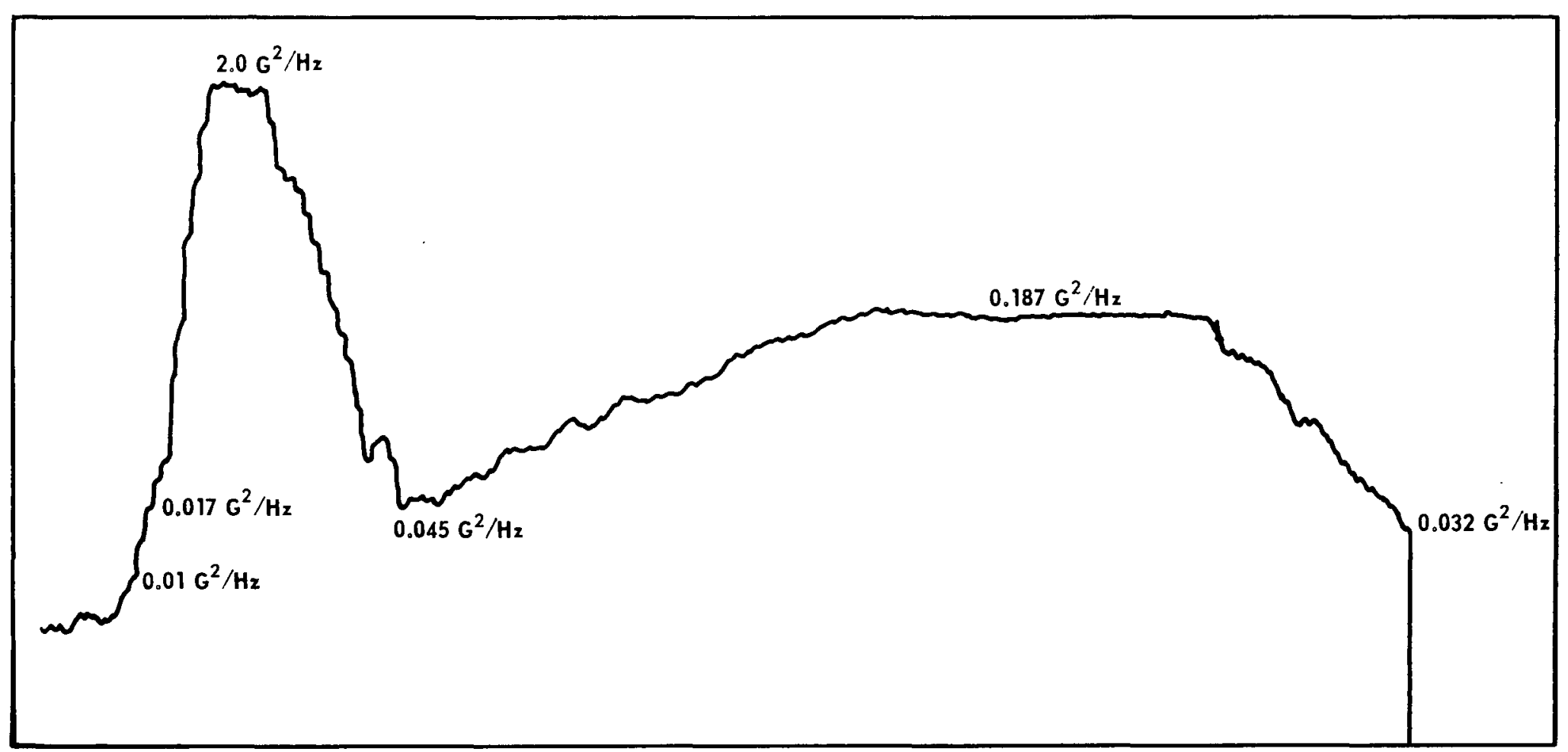

FIGURE 9 - Test \#2, Run \#13 (Nov. 8, 1972). 


\section{VIBRATION DATA SHEET}

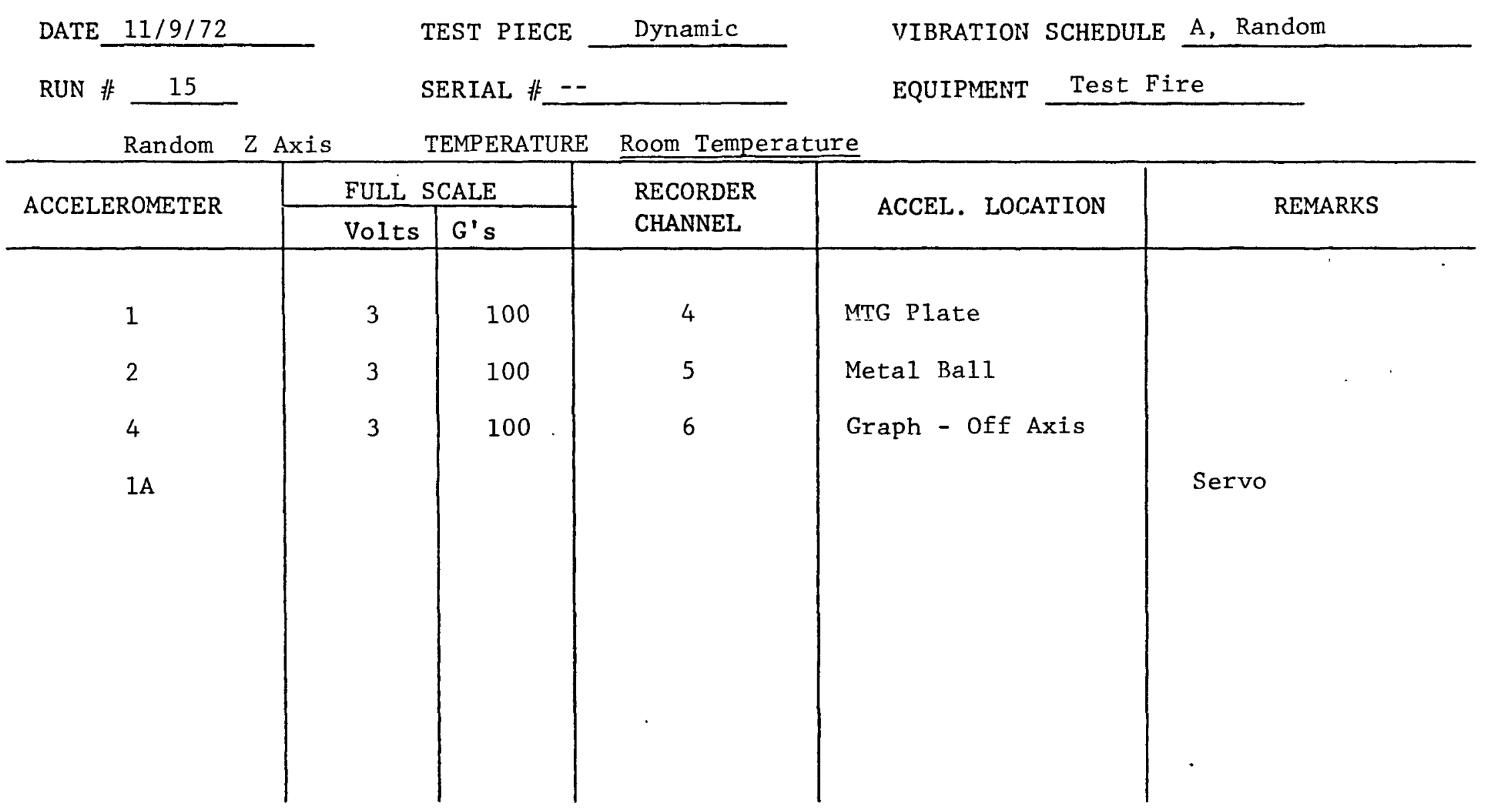





\section{VIBRATION DATA SHEET}

\begin{tabular}{lll} 
DATE $11 / 10 / 72$ & TEST PIECE Dynamic & VIBRATION SCHEDULE Sine \\
RUN 非 16 & SERIAL \# - EQ & EQUIPMENT \\
\hline
\end{tabular}

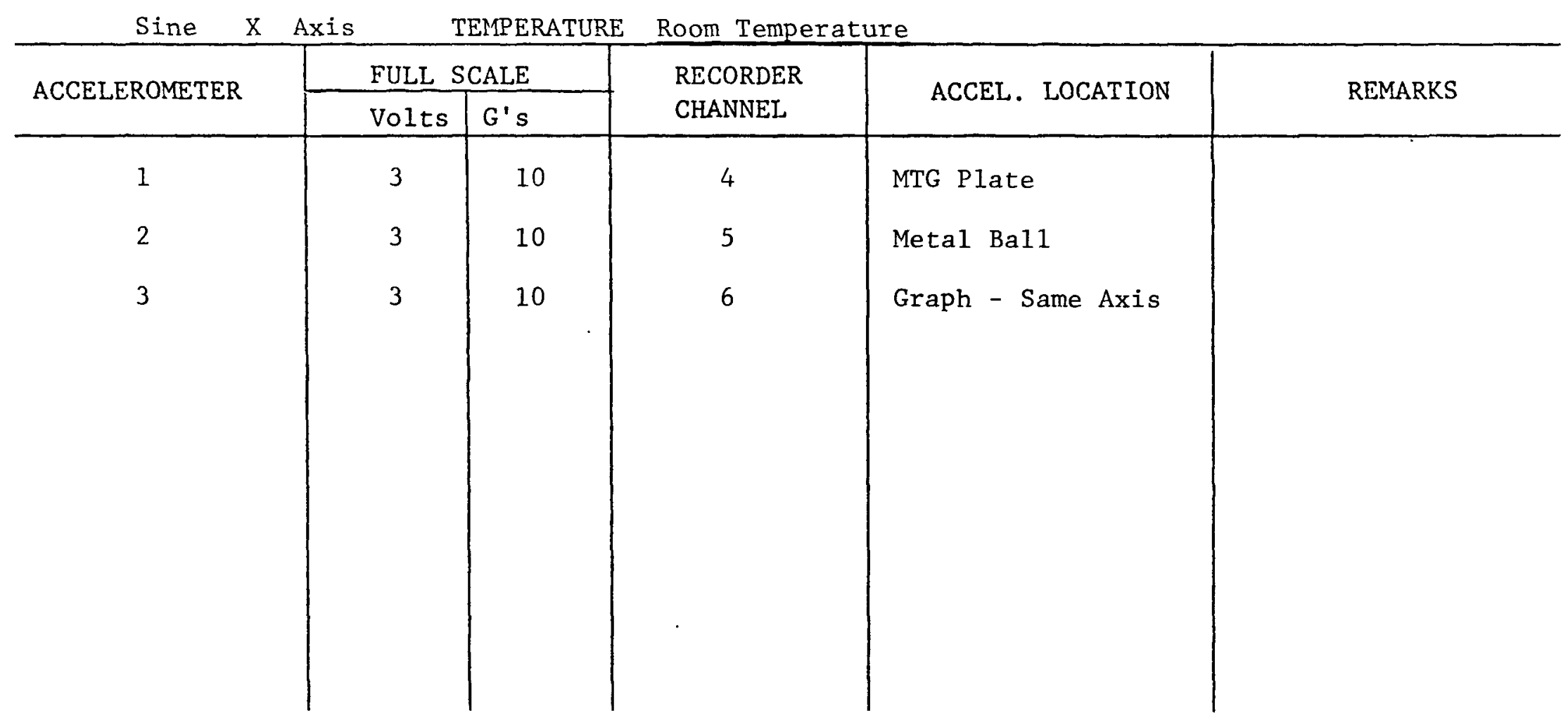


VIBRATION DATA SHEET

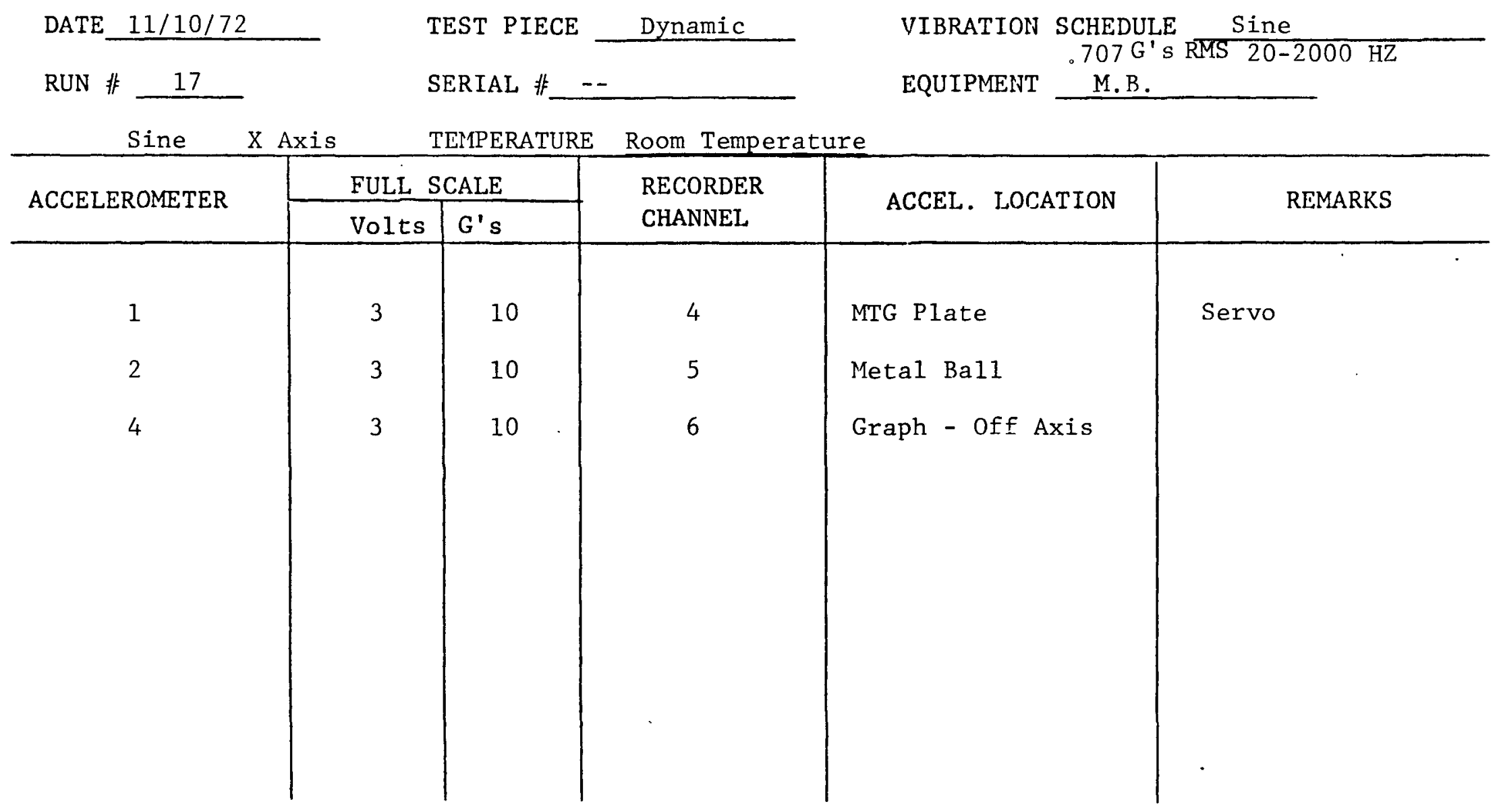




\section{VIBRATION DATA SHEET}

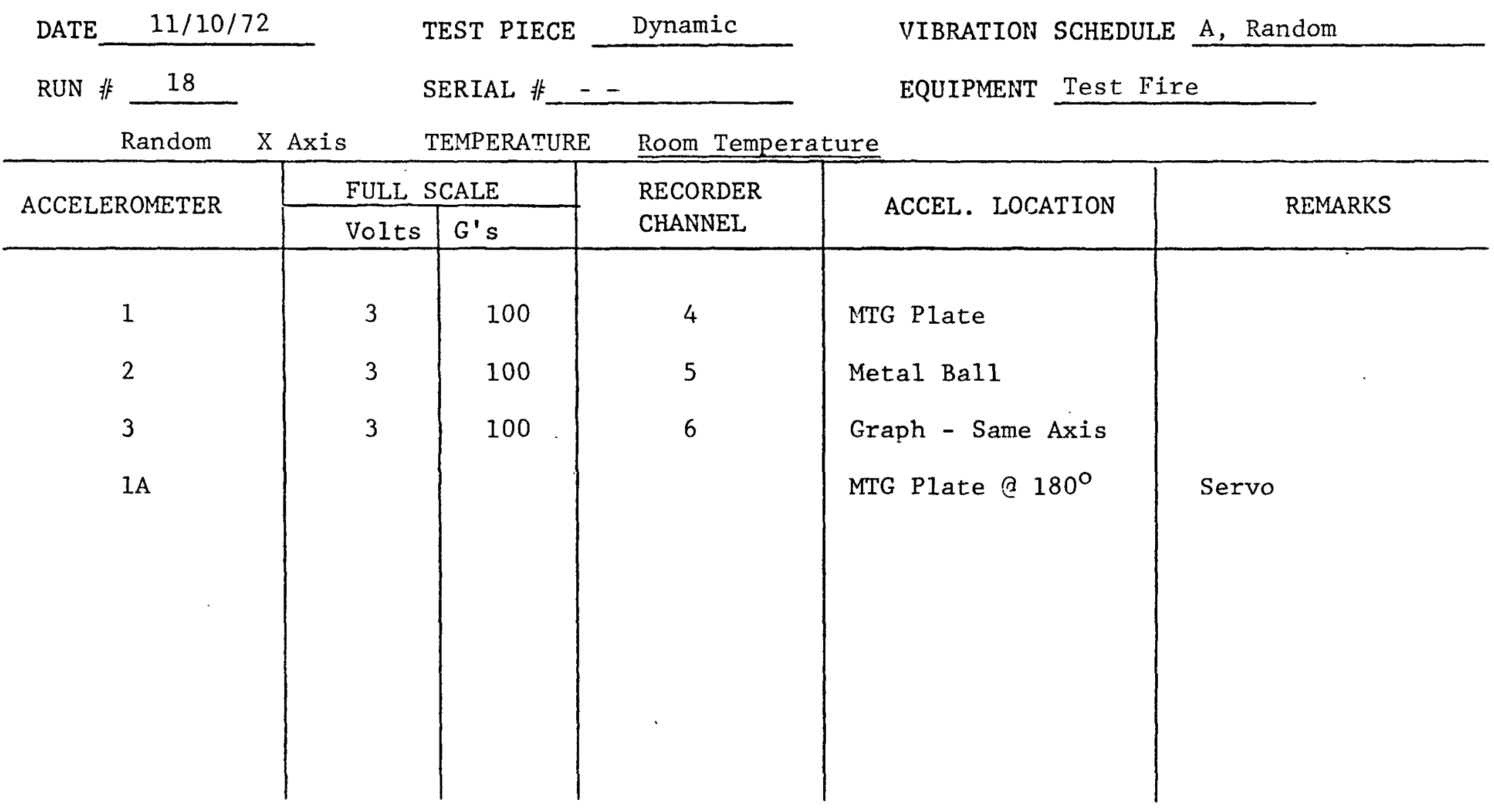




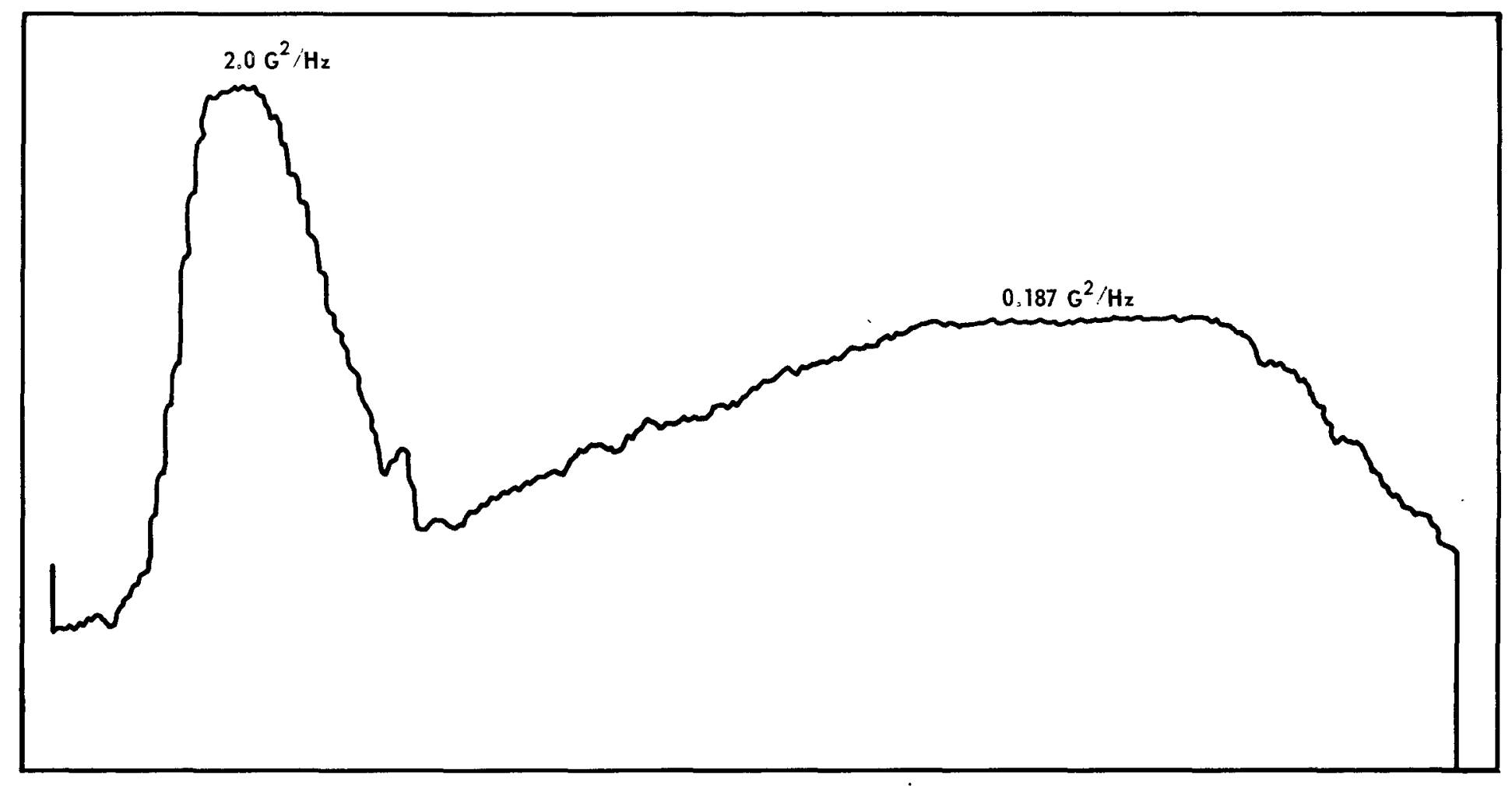

FIGURE 11 - Test. \#2, Run \#18 (Nov. 10, 1972). 
VIBRATION DATA SHEET

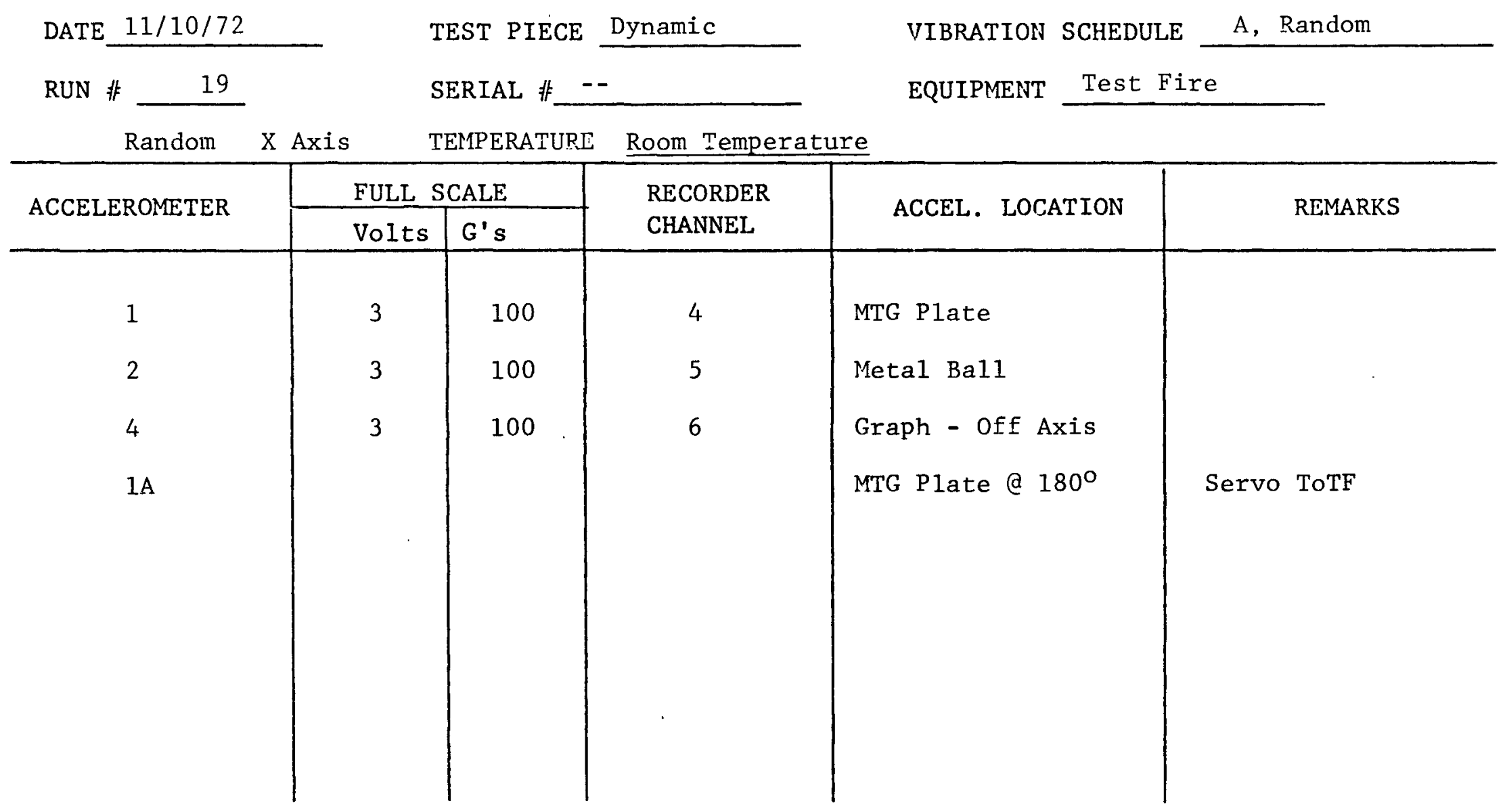


a

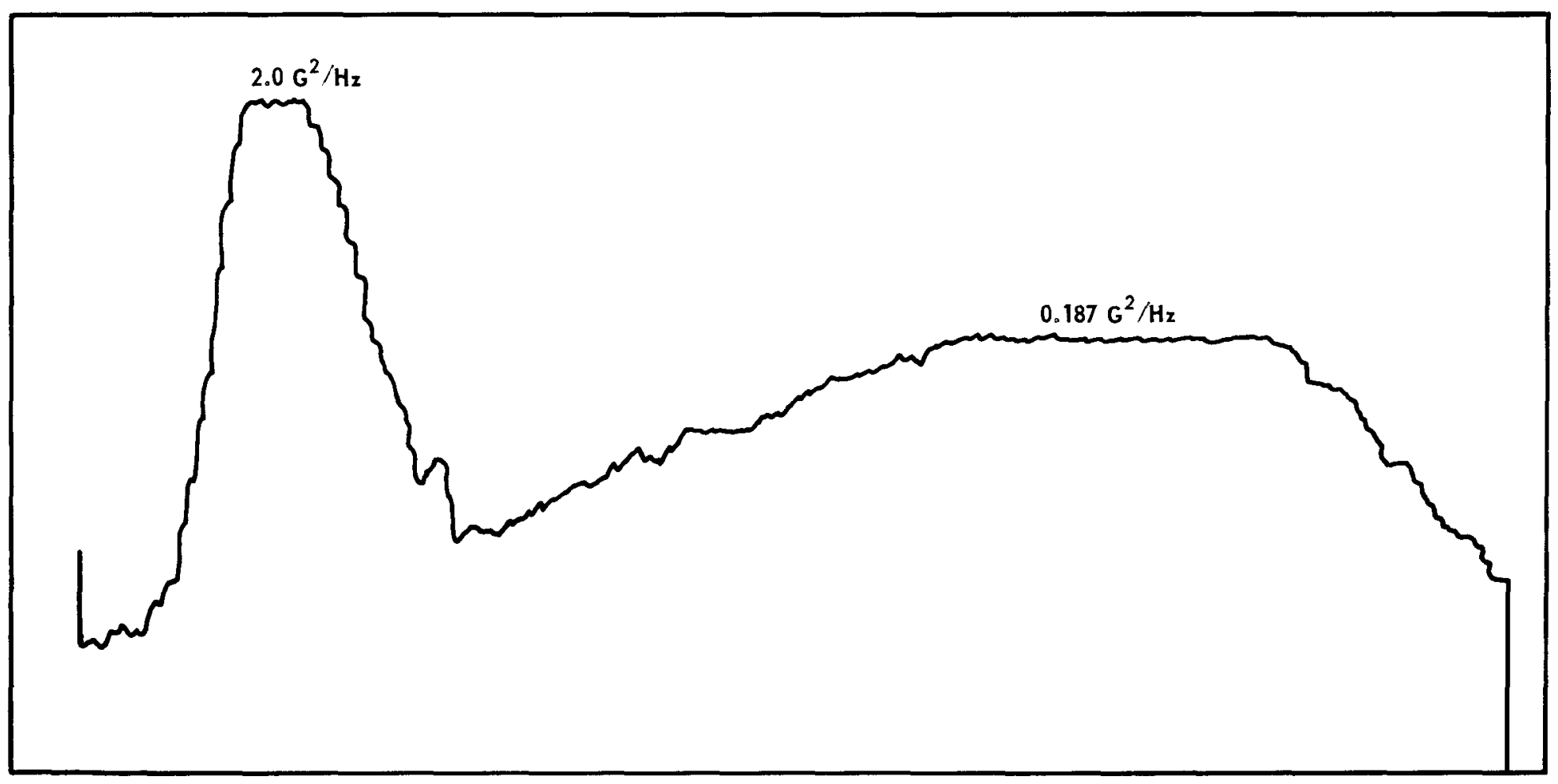

FIGURE 12 - Test \#2, Run \#19 (Nov. 10, 1972). 


\section{VIBRATION DATA SHEET}

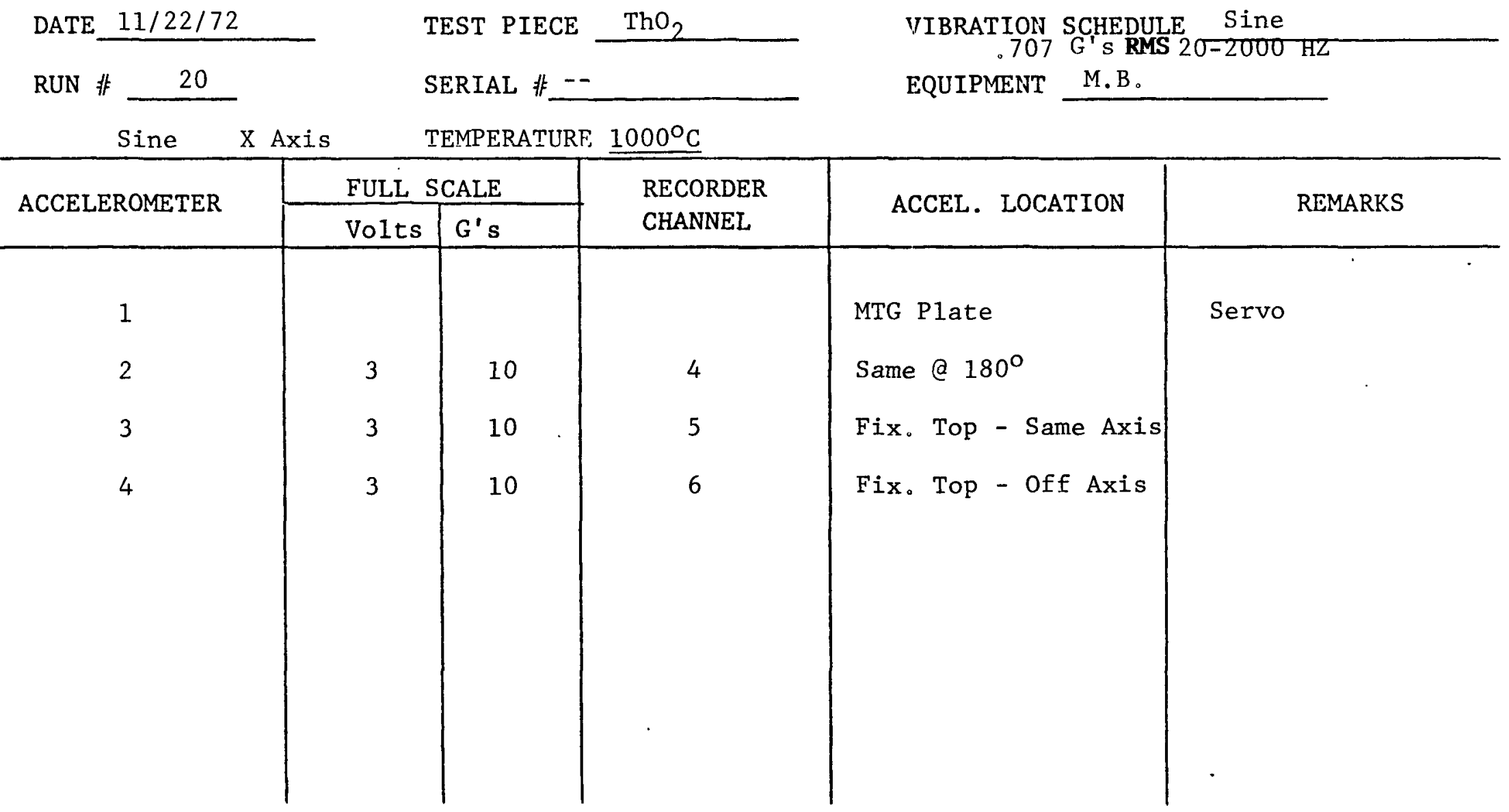




\section{VIBRATION DATA SHEET}

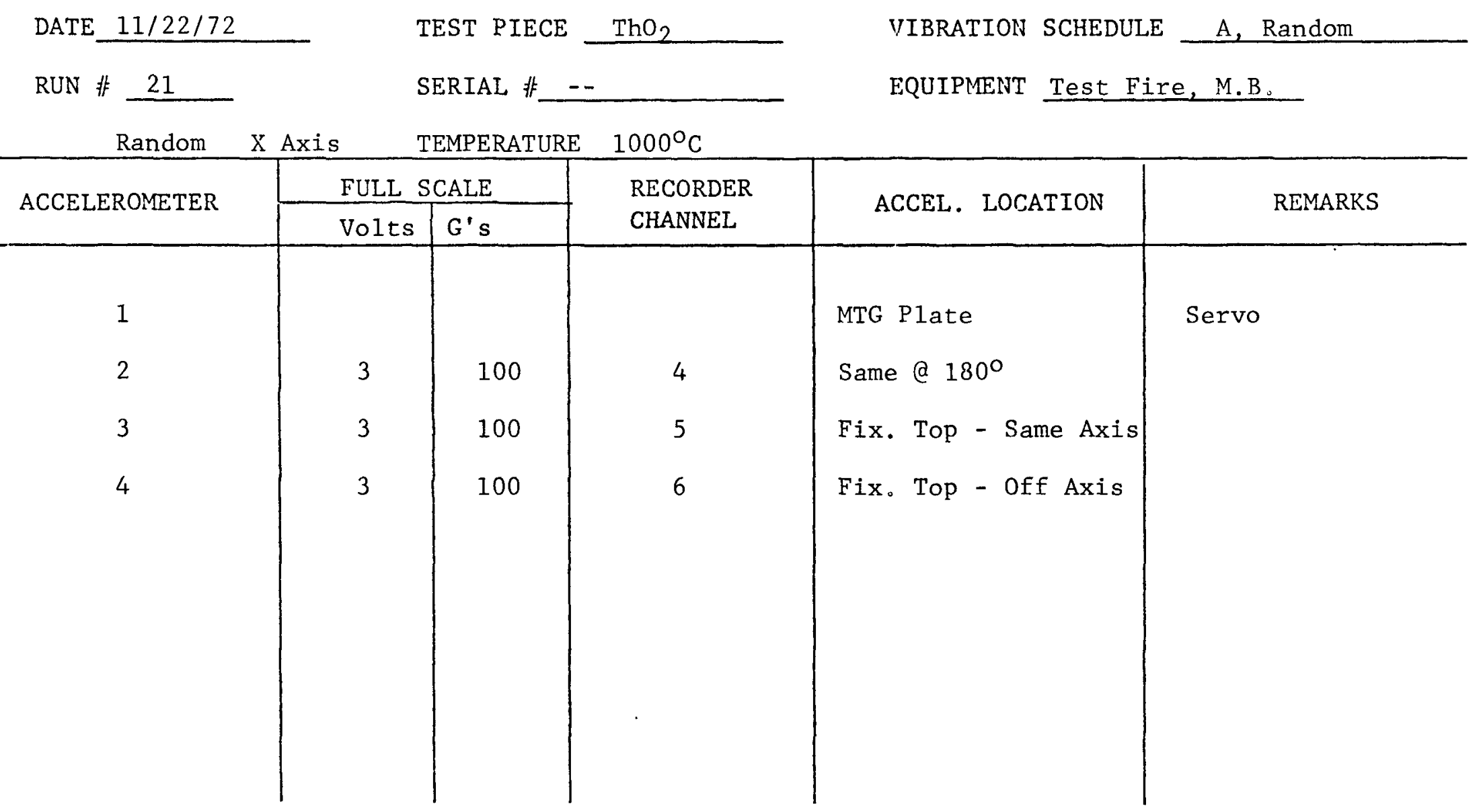




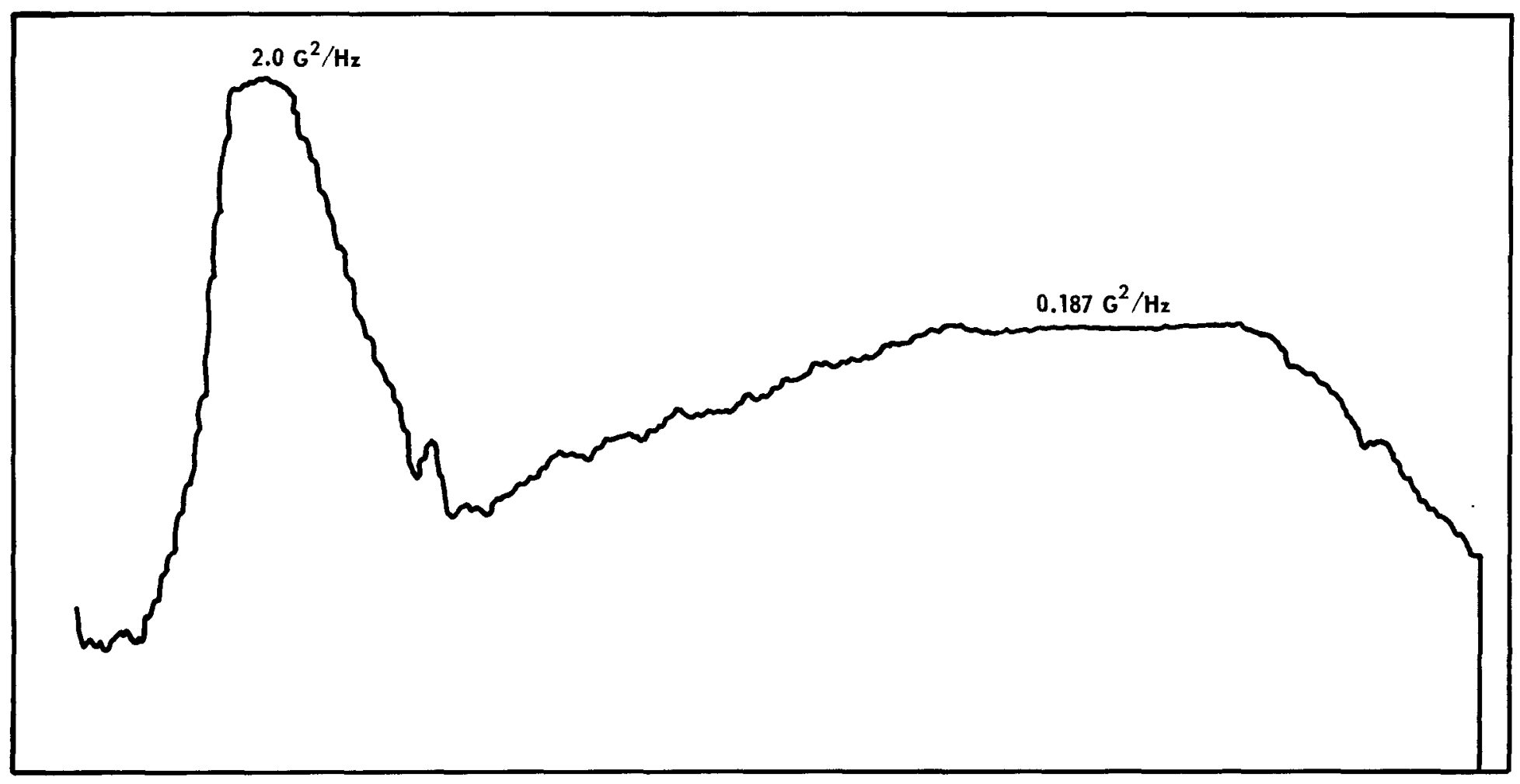

FIGURE 13 - Test.\#2, Run \#21 (Nov. 22, 1972).

f 


\section{VIBRATION DATA SHEET}

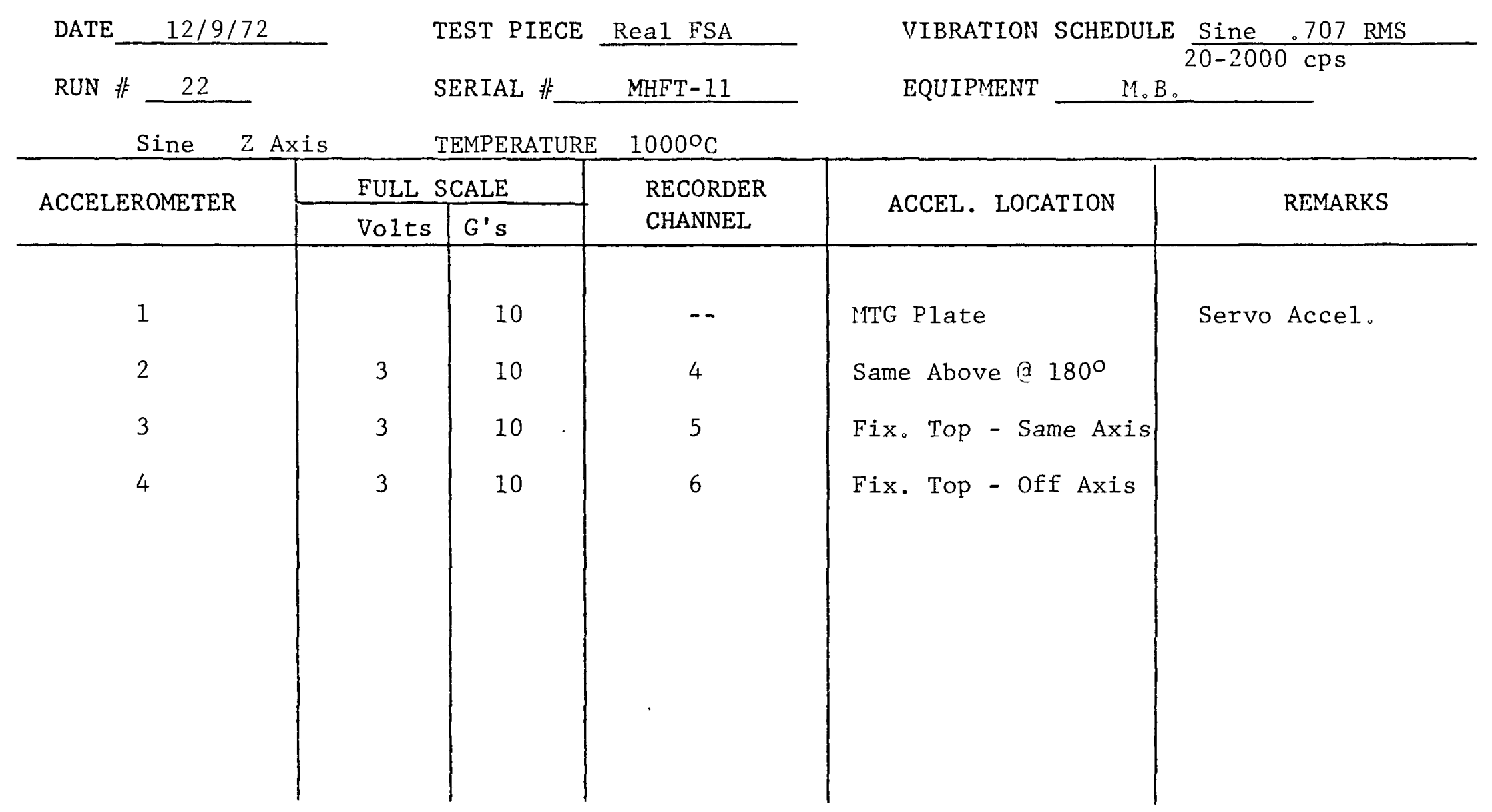




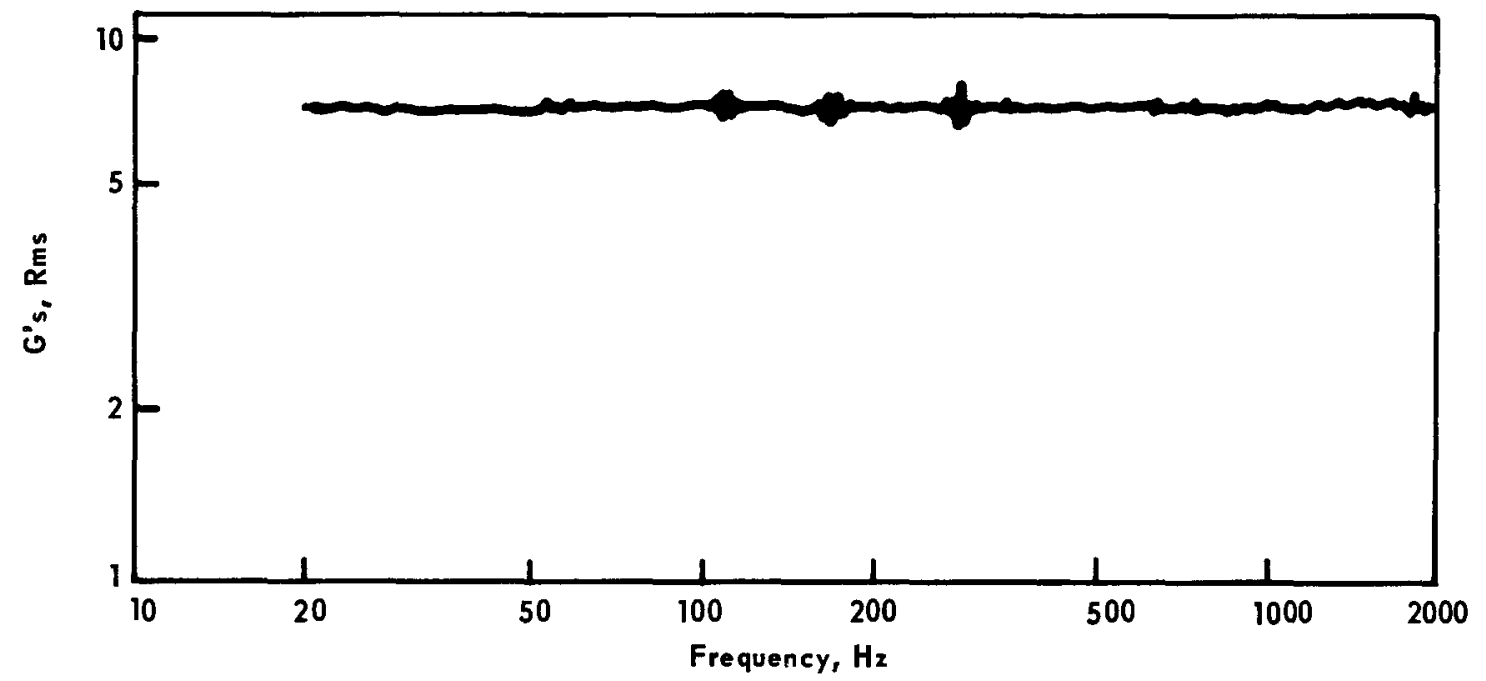

FIGURE 14 - Sine Run \#22 (Dec. 9, 1972). 
VIBRATION DATA SHEET

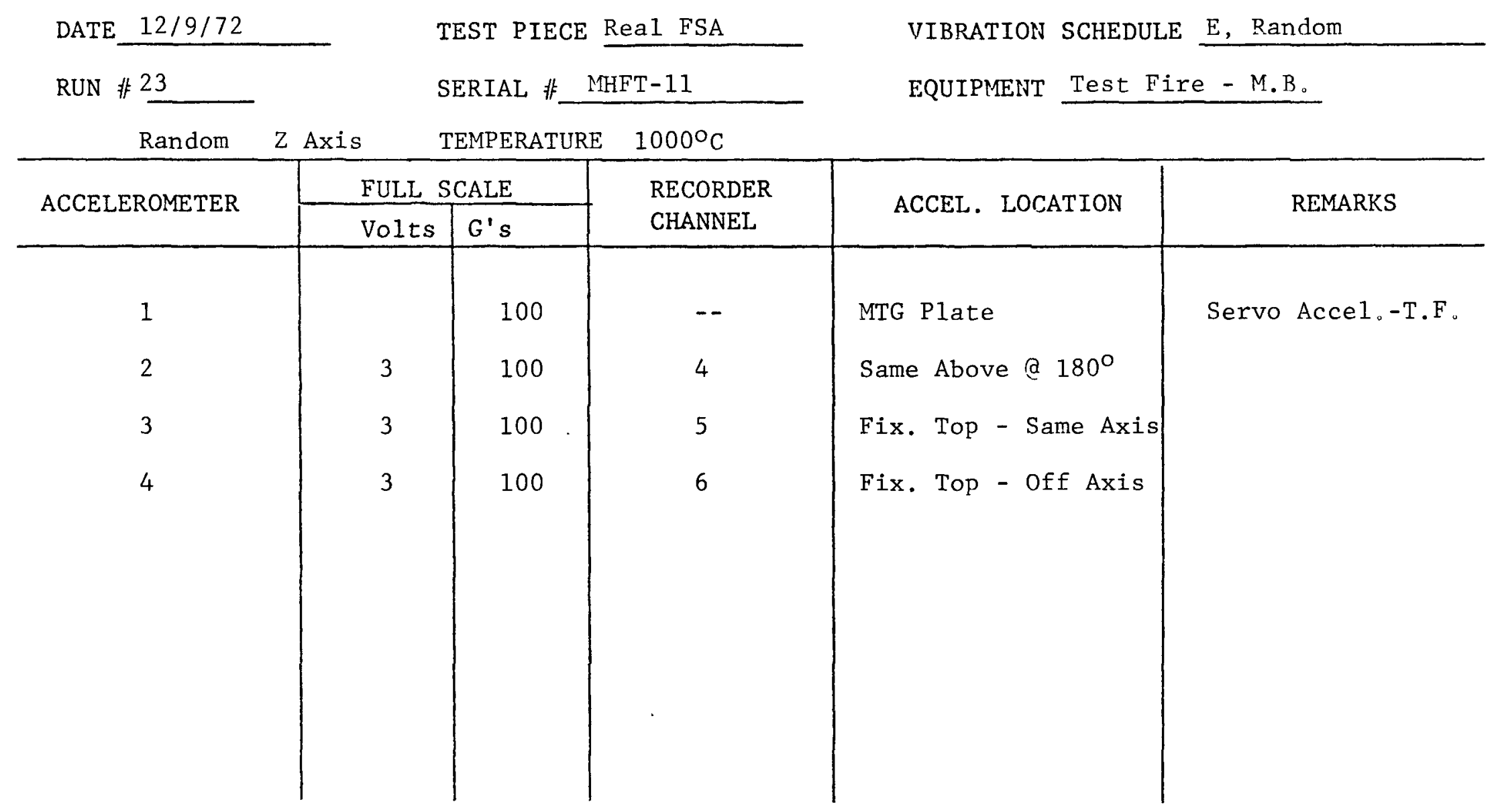




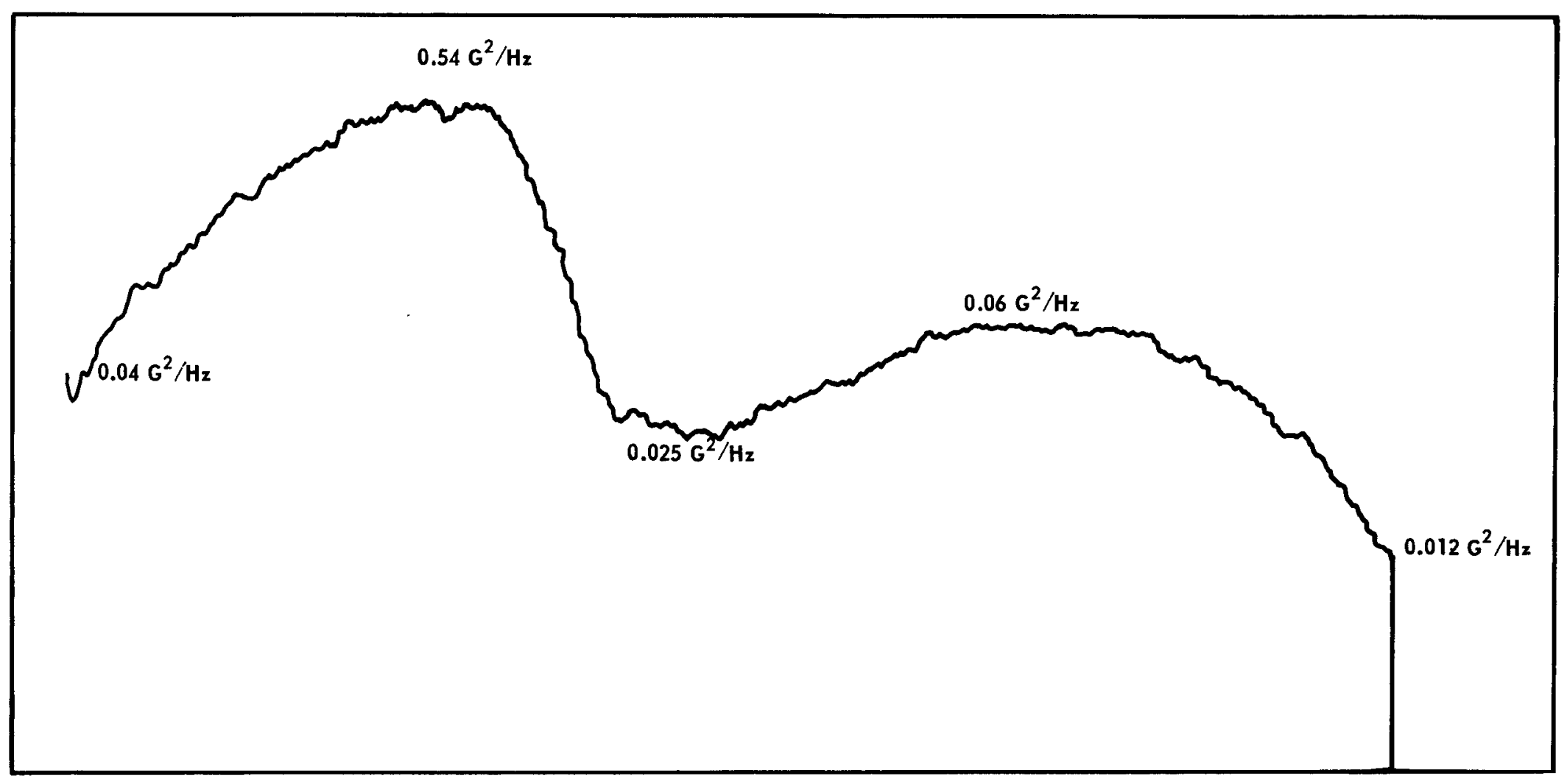

FIGURE 15 - Actual Run \#23 (Dec. 9, 1972).

$w$ 


\section{VIBRATION DATA SHEET}

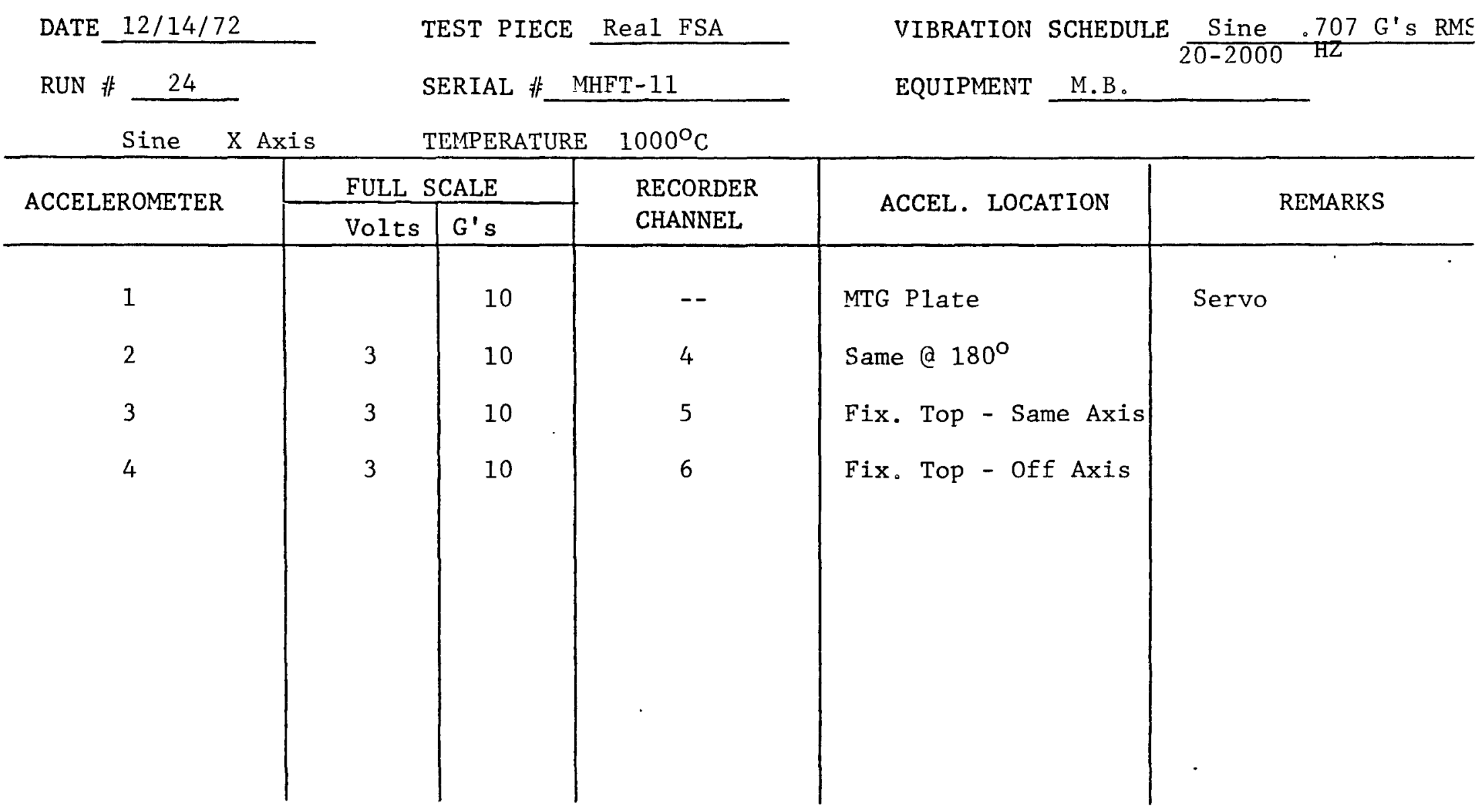




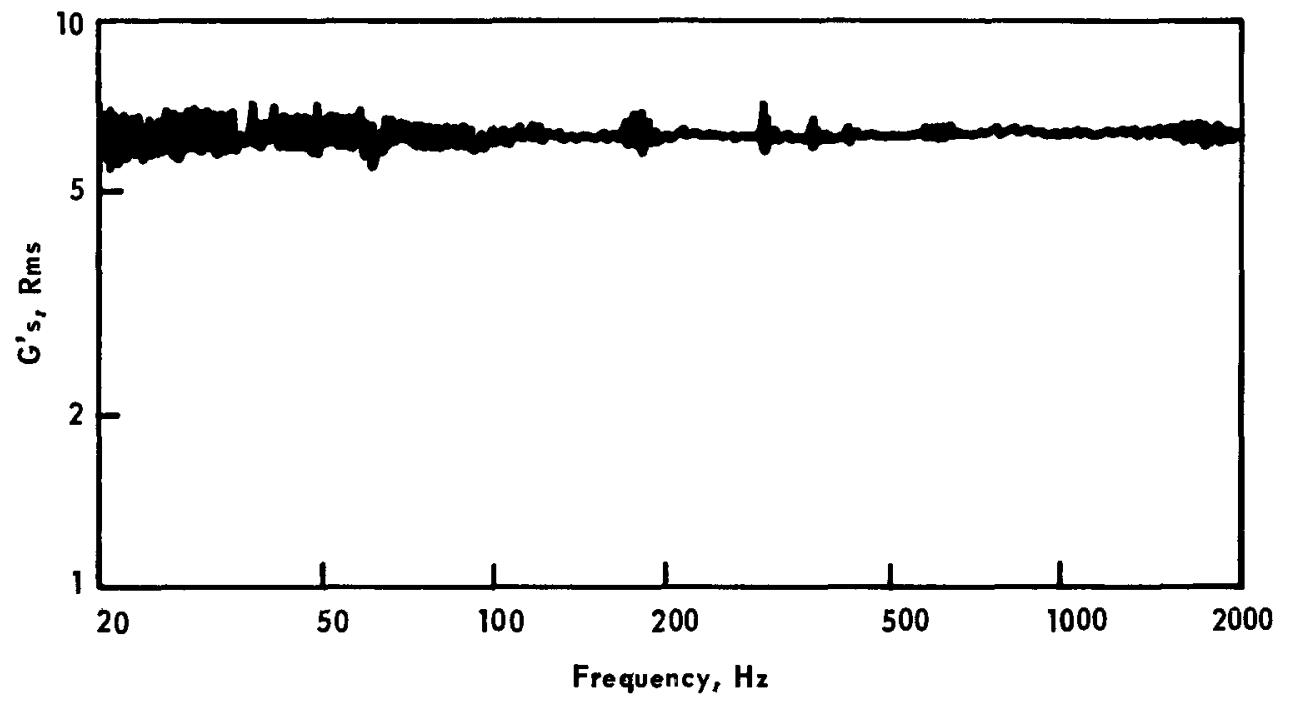

FIGURE 16 - Sine Run \#24, $x$ axis (Dec. 14, 1972). 
VIBRATION DATA SHEET

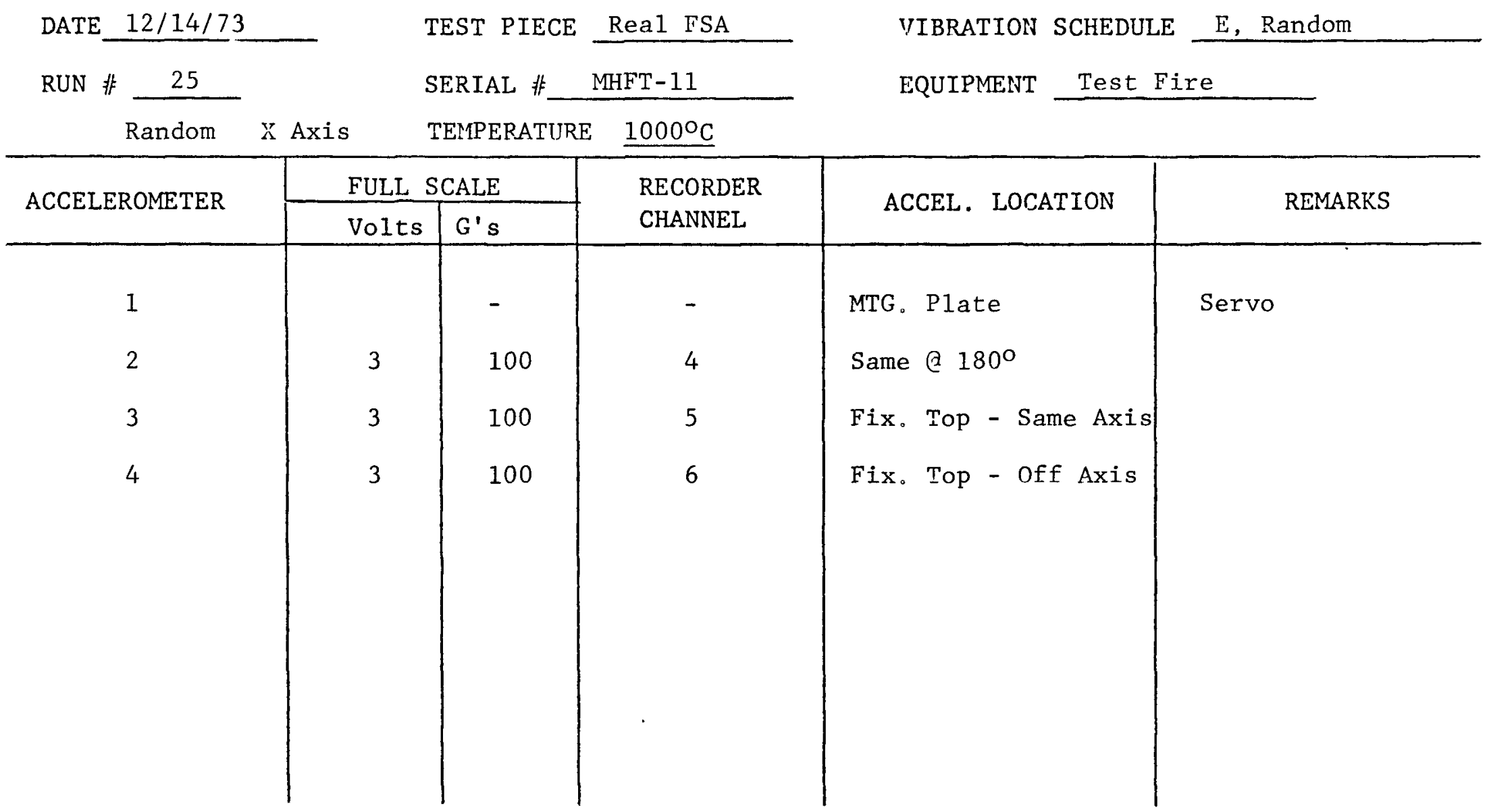




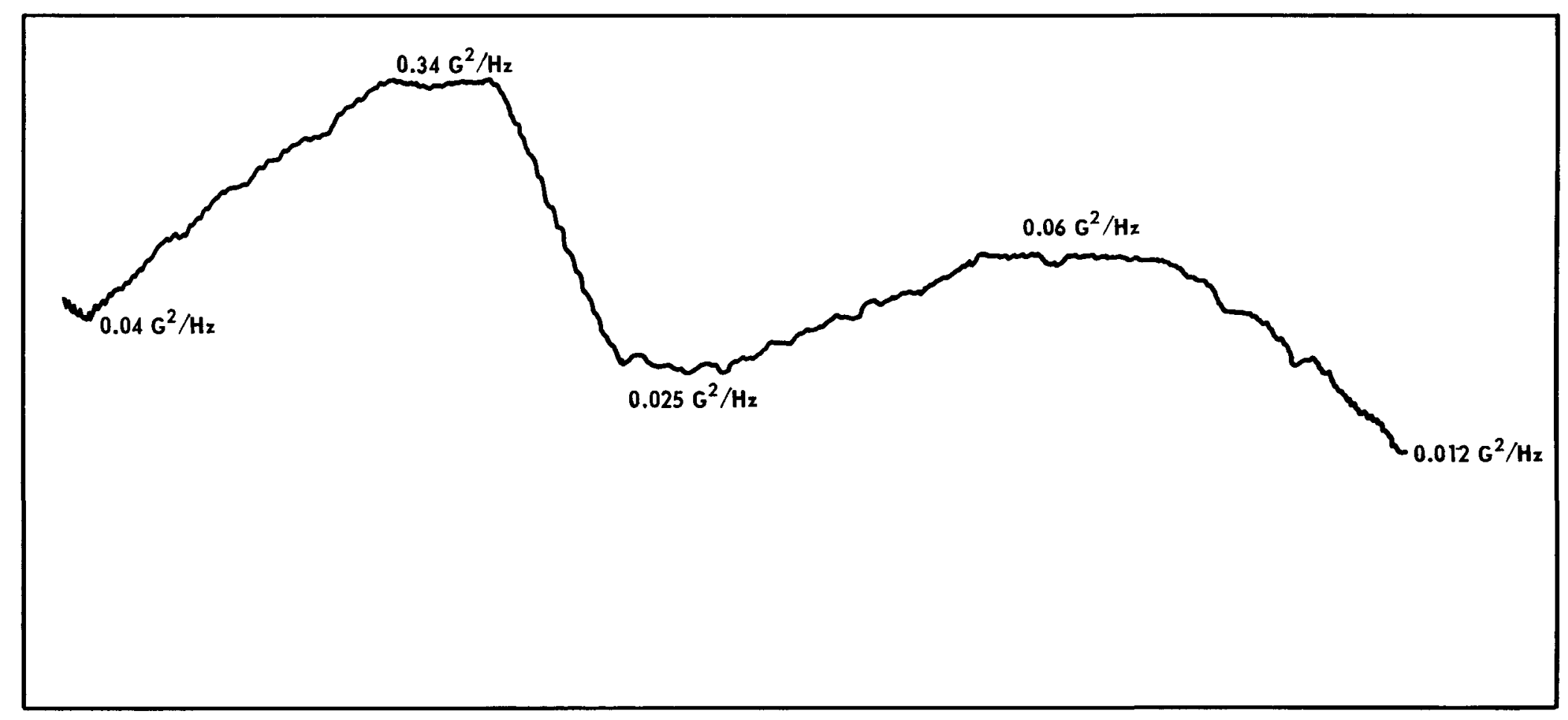

FIGURE 17 - Actual Run \#25 (Dec. 14, 1972). 
VIBRATION DATA SHEET

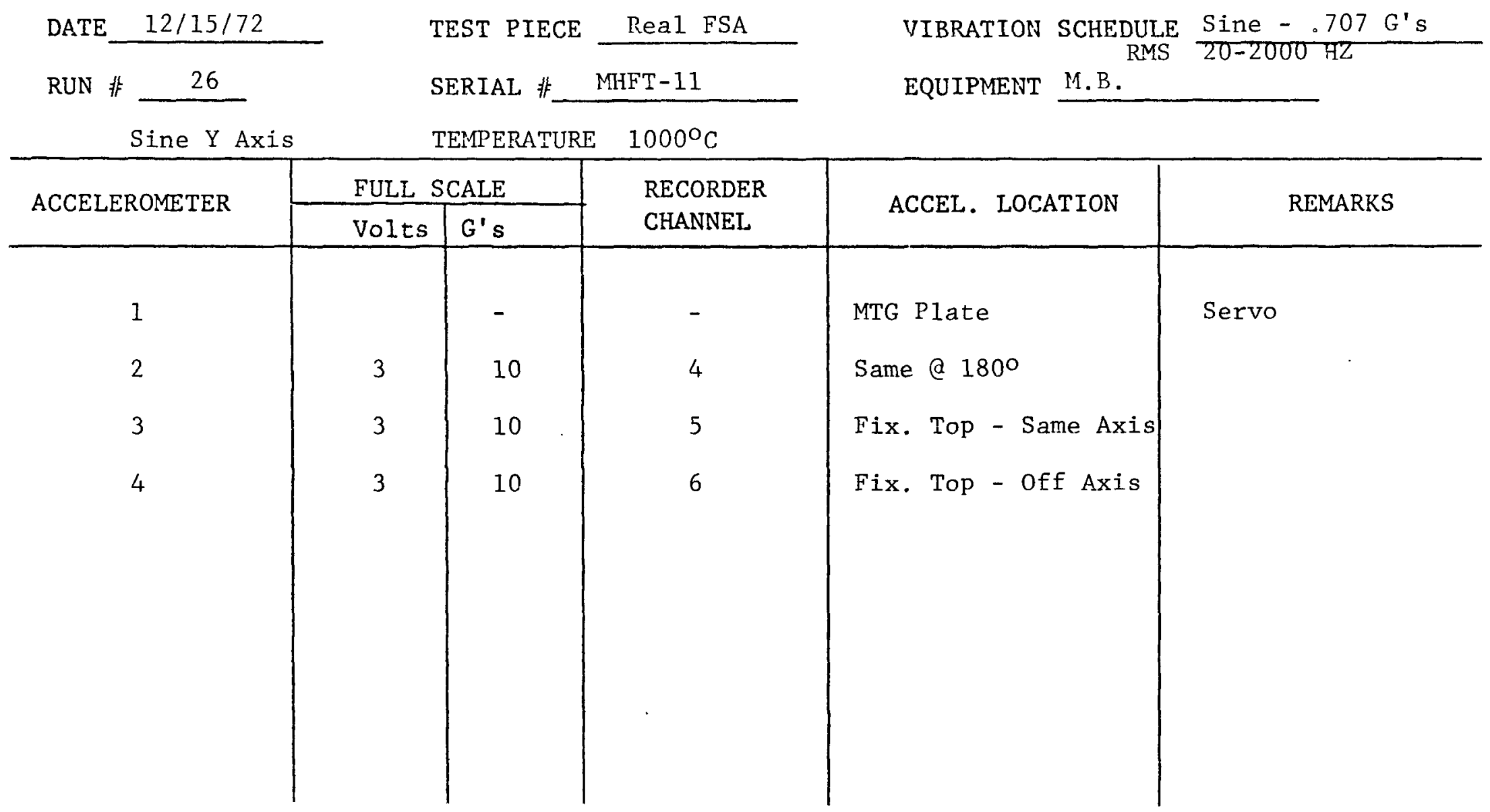




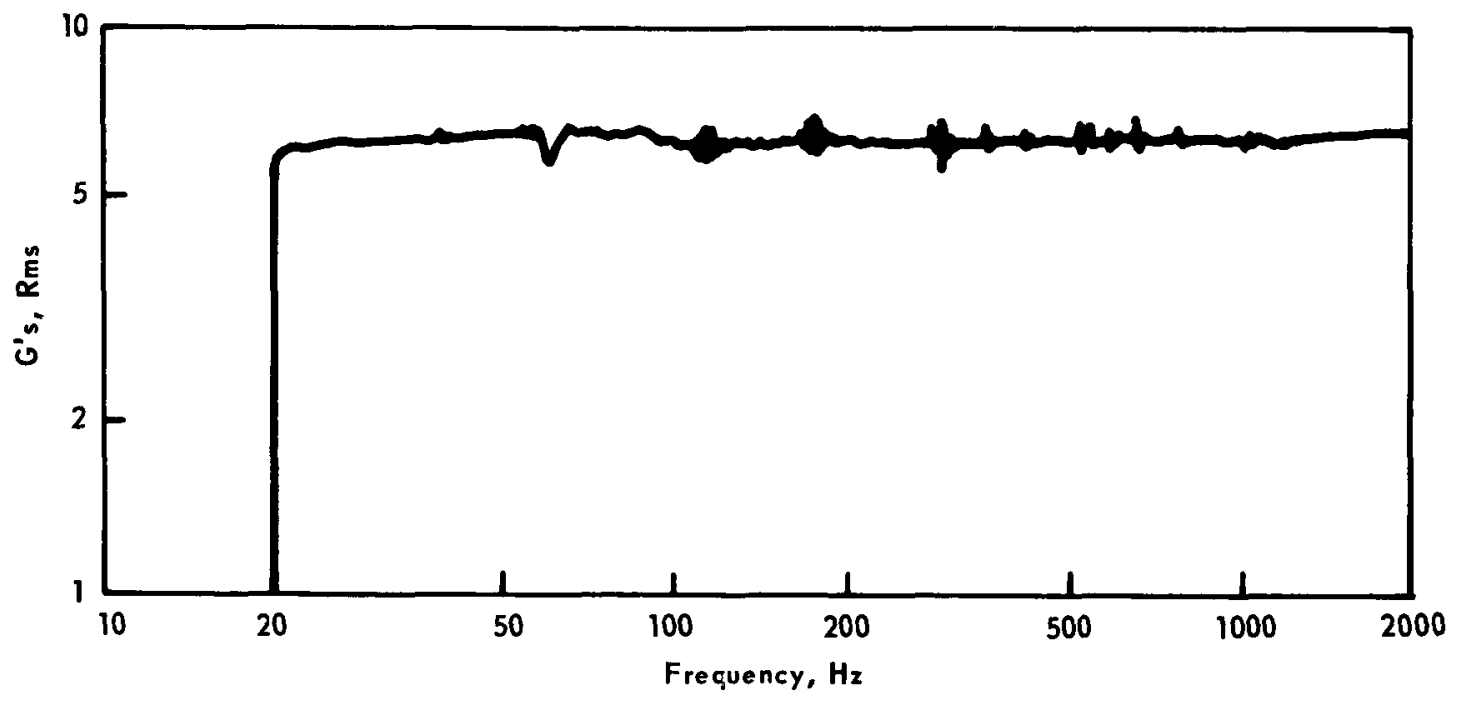

FIGURE 18 - Sine Run \#26, y axis (Dec. 15, 1972). 
VIBRATION DATA SHEET

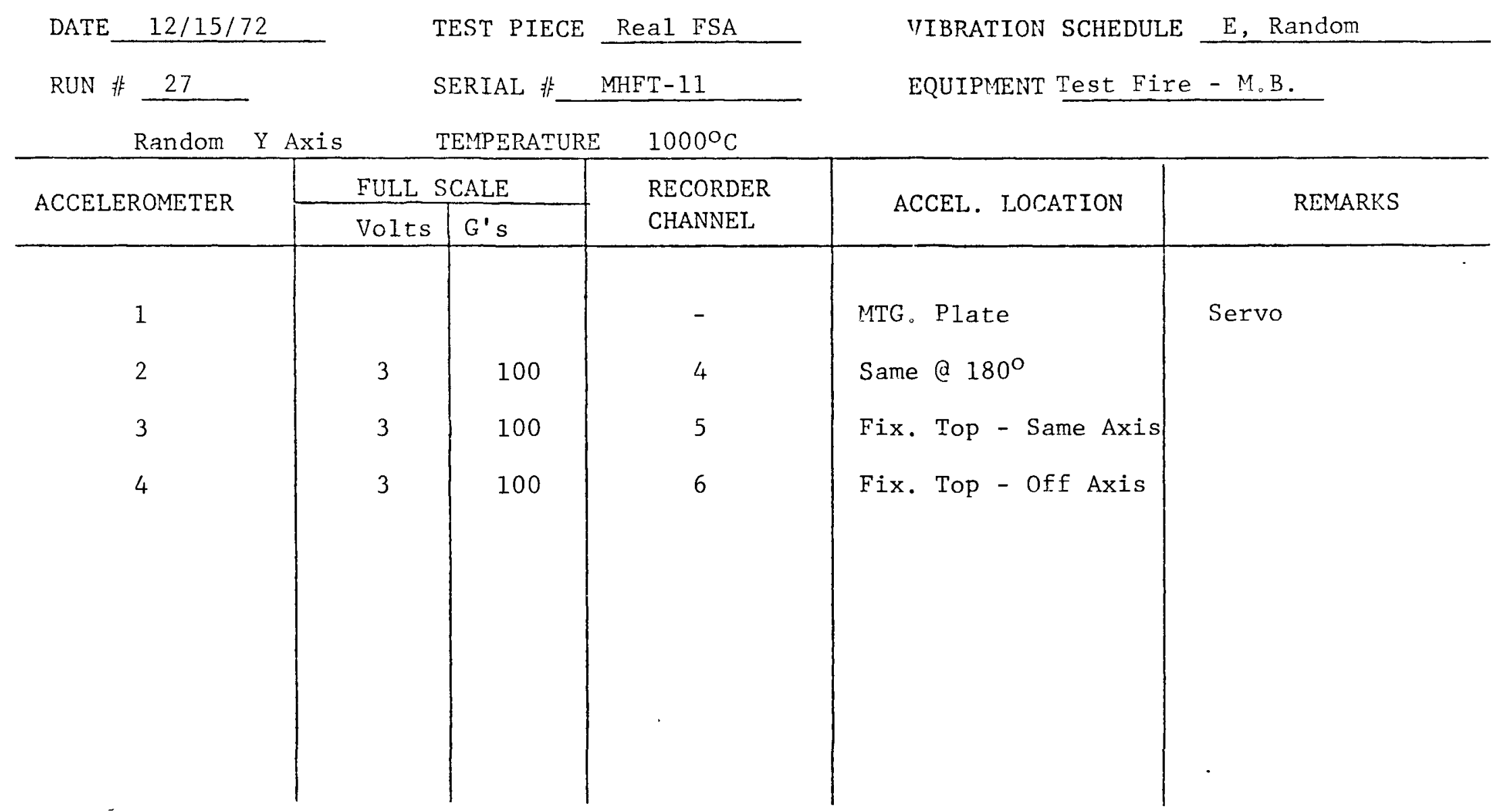




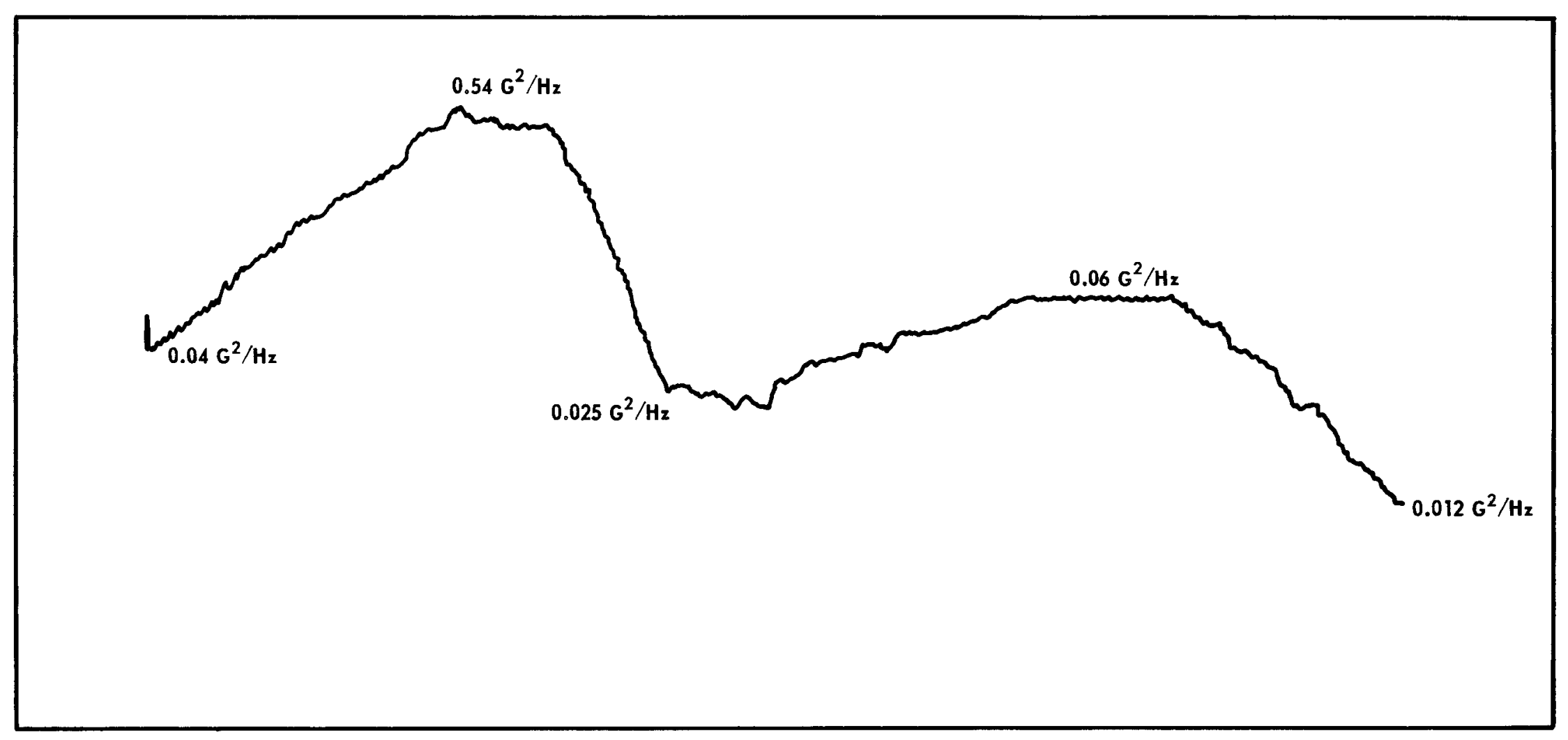

FIGURE 19 - Actual Run \#27 (Dec. 15, 1972). 
Blank page 


\author{
ATTACHMENT E \\ POST-TEST INSPECTION COMMENTS
}

Date: $12-19-72$

\title{
RADIOGRAPHIC INSPECTION REPORT
}

ITEM: MULTIHUNDRED WATT SPHERE

The sphere was radiographed at $0^{\circ}, 90^{\circ}$, and pole to inspect for condition of the sphere after tests.

Inspection results are as follows:

MHFT-11

(1) The sphere appears to be broken into three or four major sections with several smaller pieces.

(2) No indication of any appreciable amount of fine material in fuel cavity.

(3) No apparent damage to sphere encapsulation.

NOTE: Before tests, radiographs indicated three to five cracks in the sphere 0.3 in. to $0.7 \mathrm{in.}$ in length but the sphere appeared to be intact. 
Applied Technology, TR-27

January 3, 1973

Telephone Conversation Between

C. O. Brewer and R. N. R. Mulford

of LASL

S. G. Abrahamson

Mr. Mulford called to give the preliminary visual observations of MHFT-11, the vibration test capsule. He said that the inside of the iridium was very clean with no visual black deposit. The only damage noted was the weld shield bond had broken away at the tack welds.

The fuel sphere was broken into eight (8) pieces, five (5) large and three (3) small; however, no fines had been determined to date.

C. O. Brewer

COB $: \operatorname{tr}$ 


\section{VIBRATION DATA SHEET}

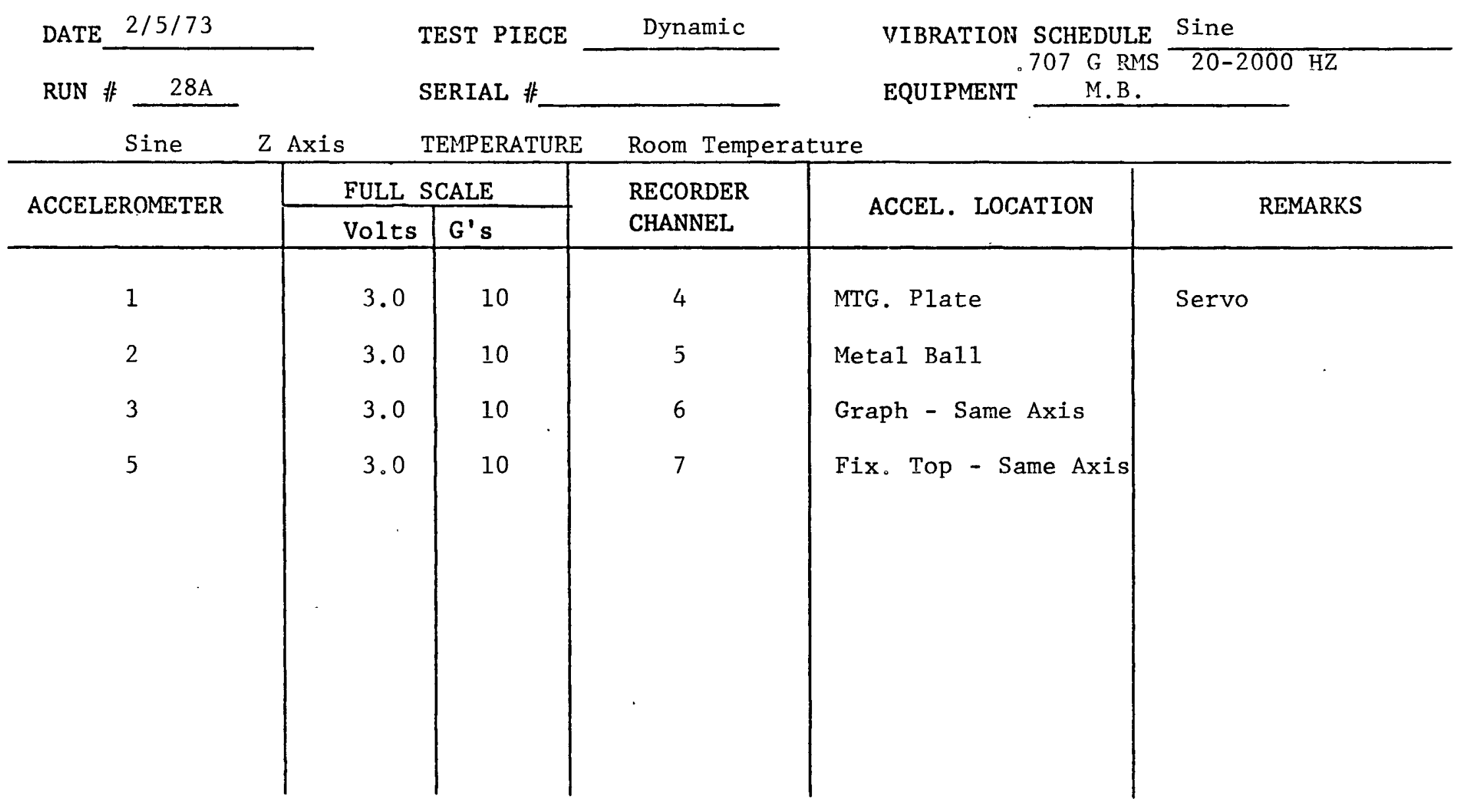




\section{VIBRATION DATA SHEET}

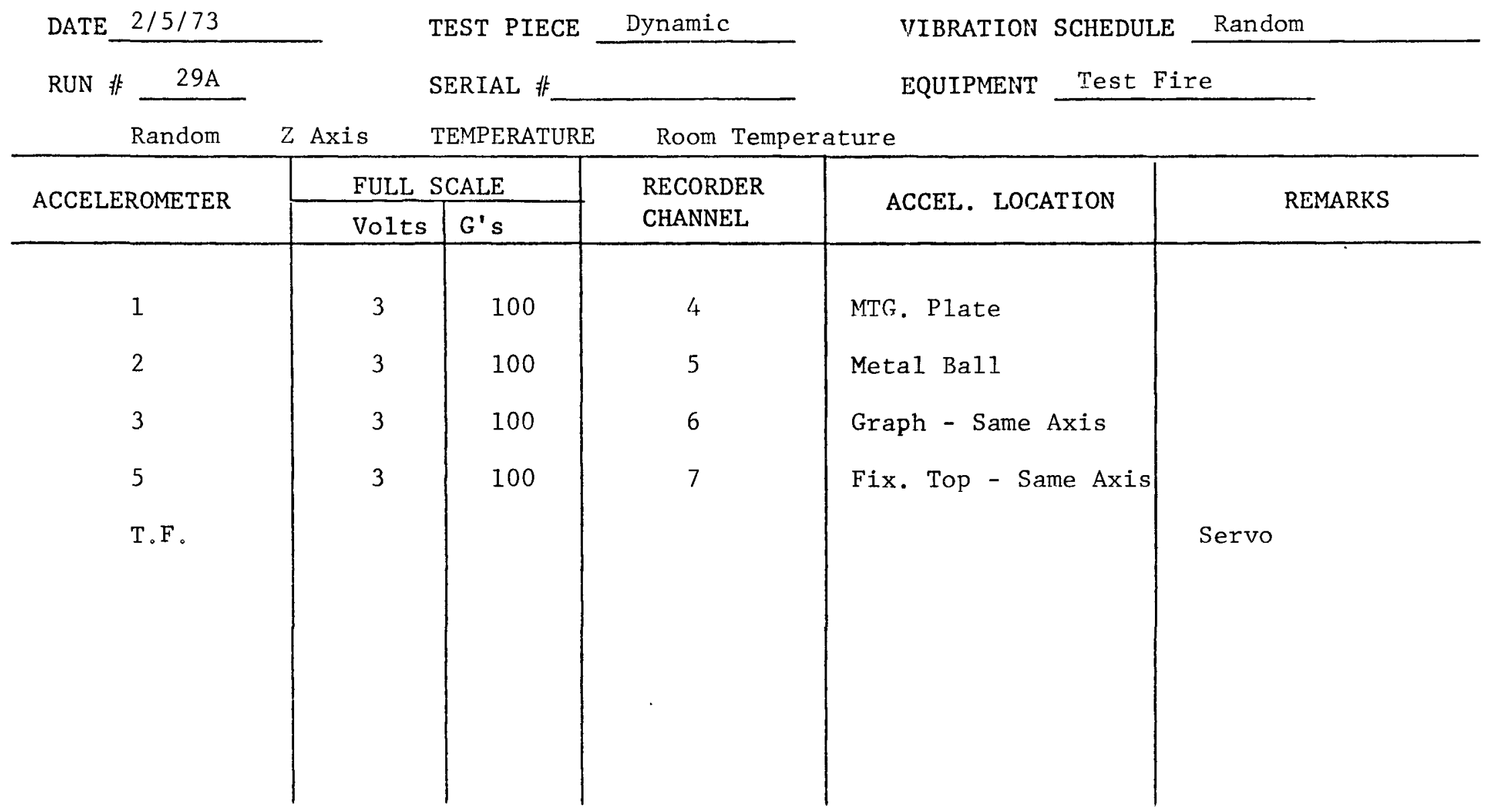




\section{VIBRATION DATA SHEET}

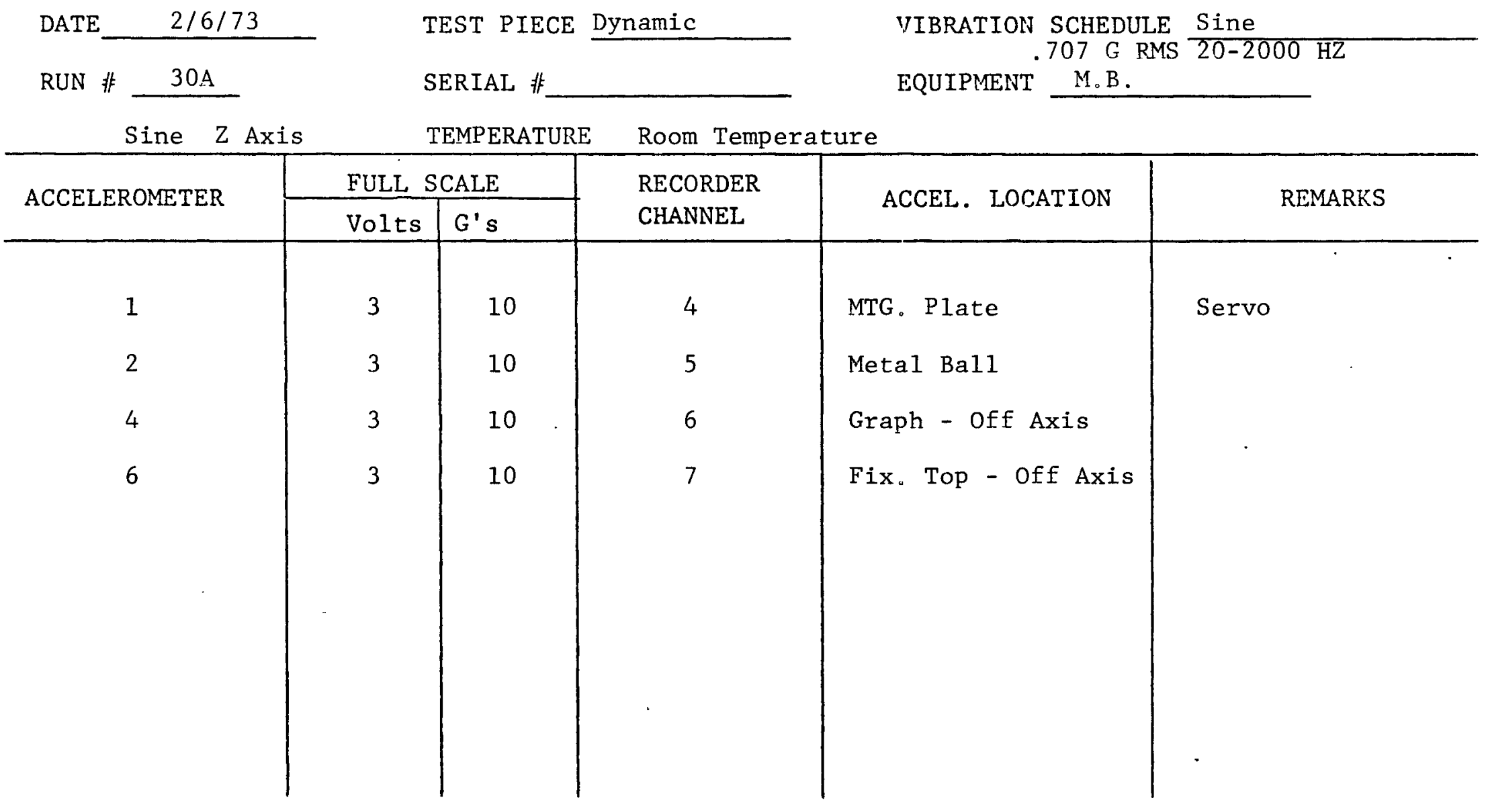




\section{VIBRATION DATA SHEET}

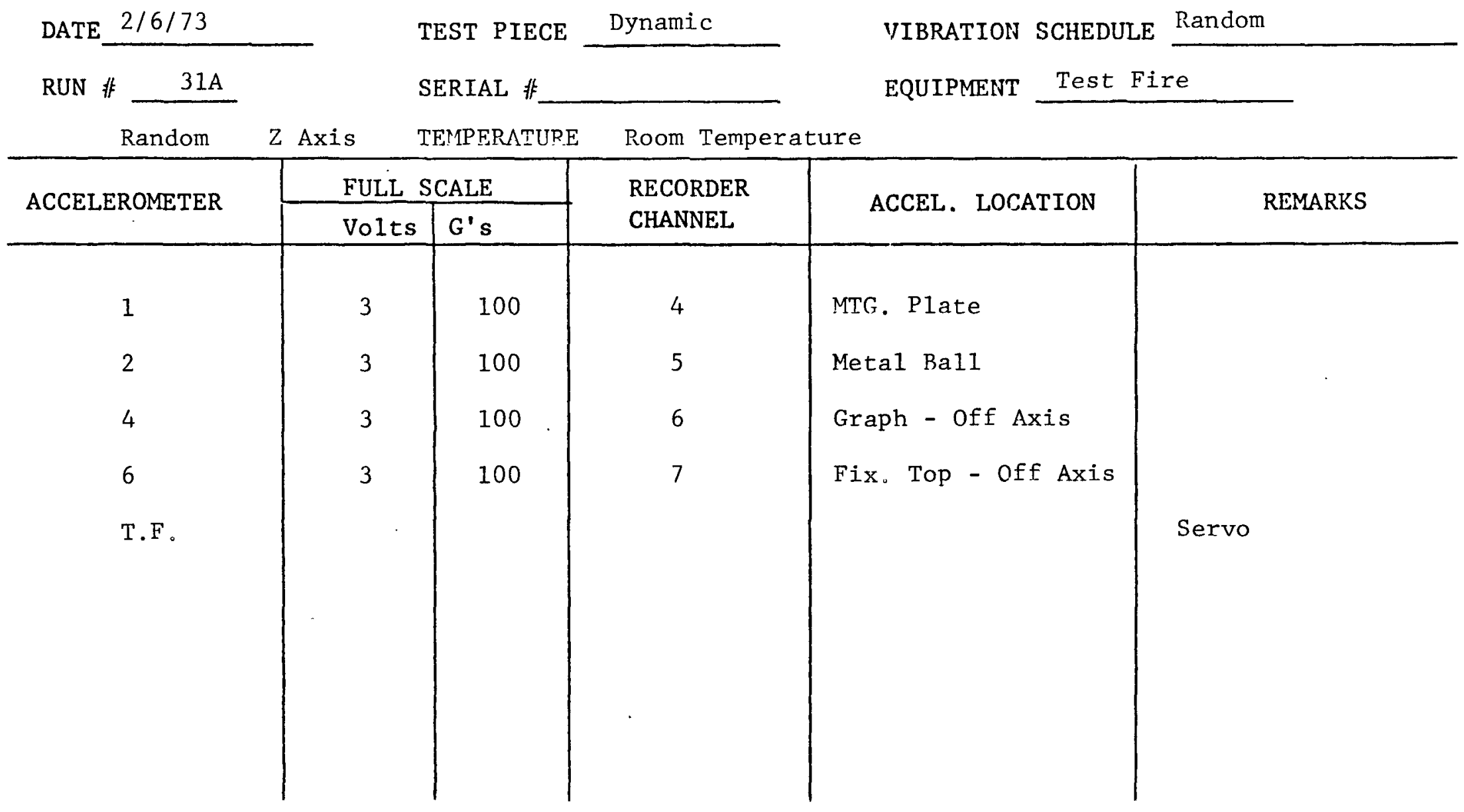




\section{VIBRATION DATA SHEET}

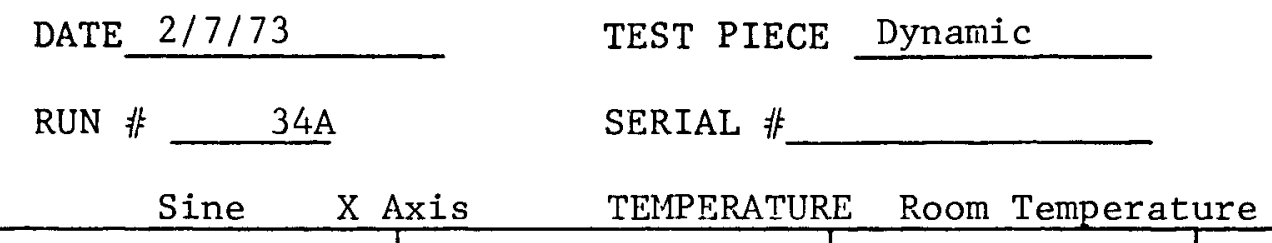

Sine $X$ Axis TEMPERATURE Room Temperature

Sine

\begin{tabular}{|c|c|c|c|c|c|}
\hline \multirow{2}{*}{ ACCELEROMETER } & \multicolumn{2}{|c|}{ FULL SCALE } & \multirow{2}{*}{$\begin{array}{l}\text { RECORDER } \\
\text { CHANNEL }\end{array}$} & \multirow{2}{*}{ ACCEL. LOCATION } & \multirow{2}{*}{ REMARKS } \\
\hline & Volts & $G^{\prime} s$ & & & \\
\hline 1 & 3 & 10 & 4 & MTG.Plate & Servo \\
\hline 2 & 3 & 10 & 5 & Metal Ball & \\
\hline 4 & 3 & 10 & 6 & Graph - Off Axis & \\
\hline 6 & 3 & 10 & 7 & Fix. Top - off Axis & \\
\hline
\end{tabular}




\section{VIBRATION DATA SHEET}

DATE $2 / 7 / 73$

TEST PIECE Dynamic

SERIAL 非 --

\begin{tabular}{l} 
VIBRATION SCHEDULE \\
EQUIPMENT Test Fire M.B. \\
\hline
\end{tabular}

RUN 非 $\quad 35 \mathrm{~A}$

TEMPERATURE Room Temperature

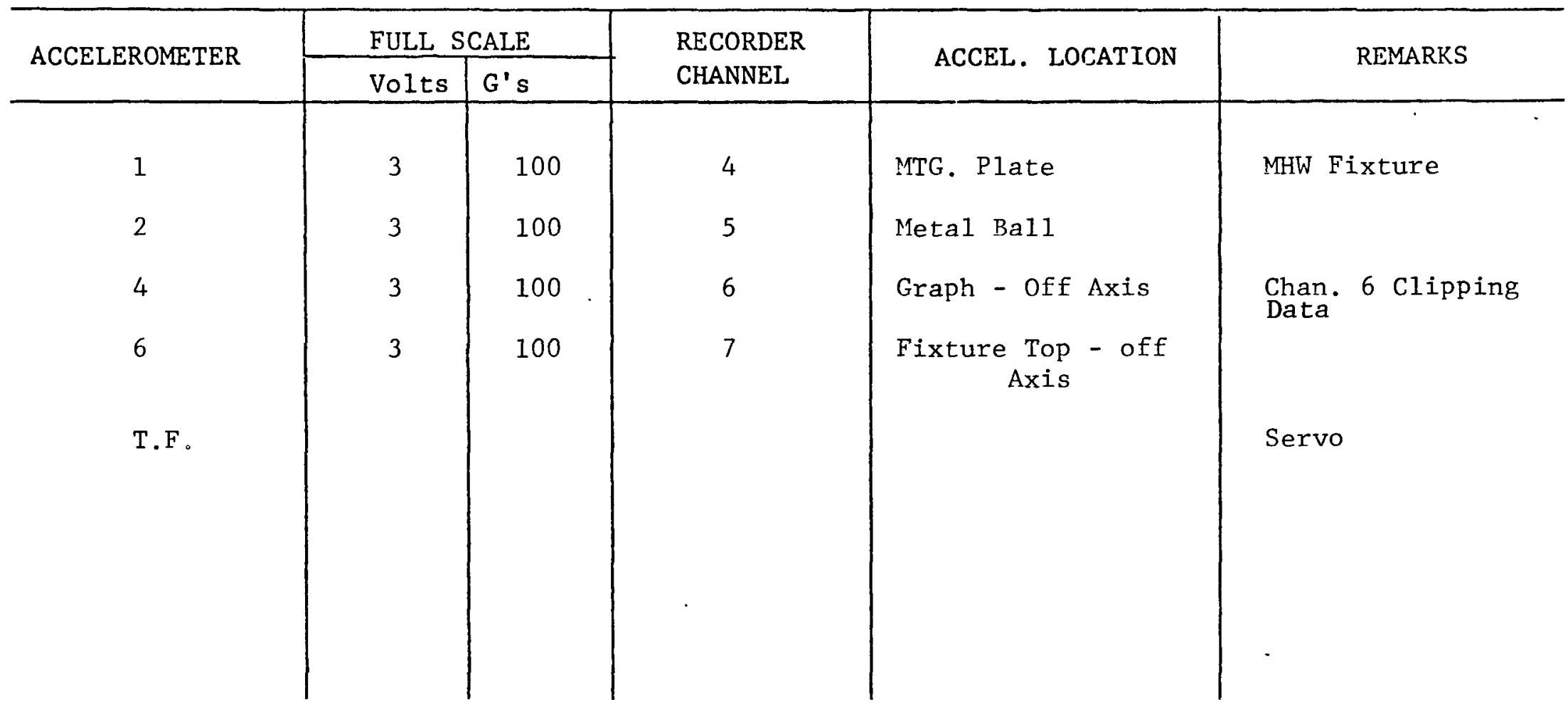




\section{VIBRATION DATA SHEET}

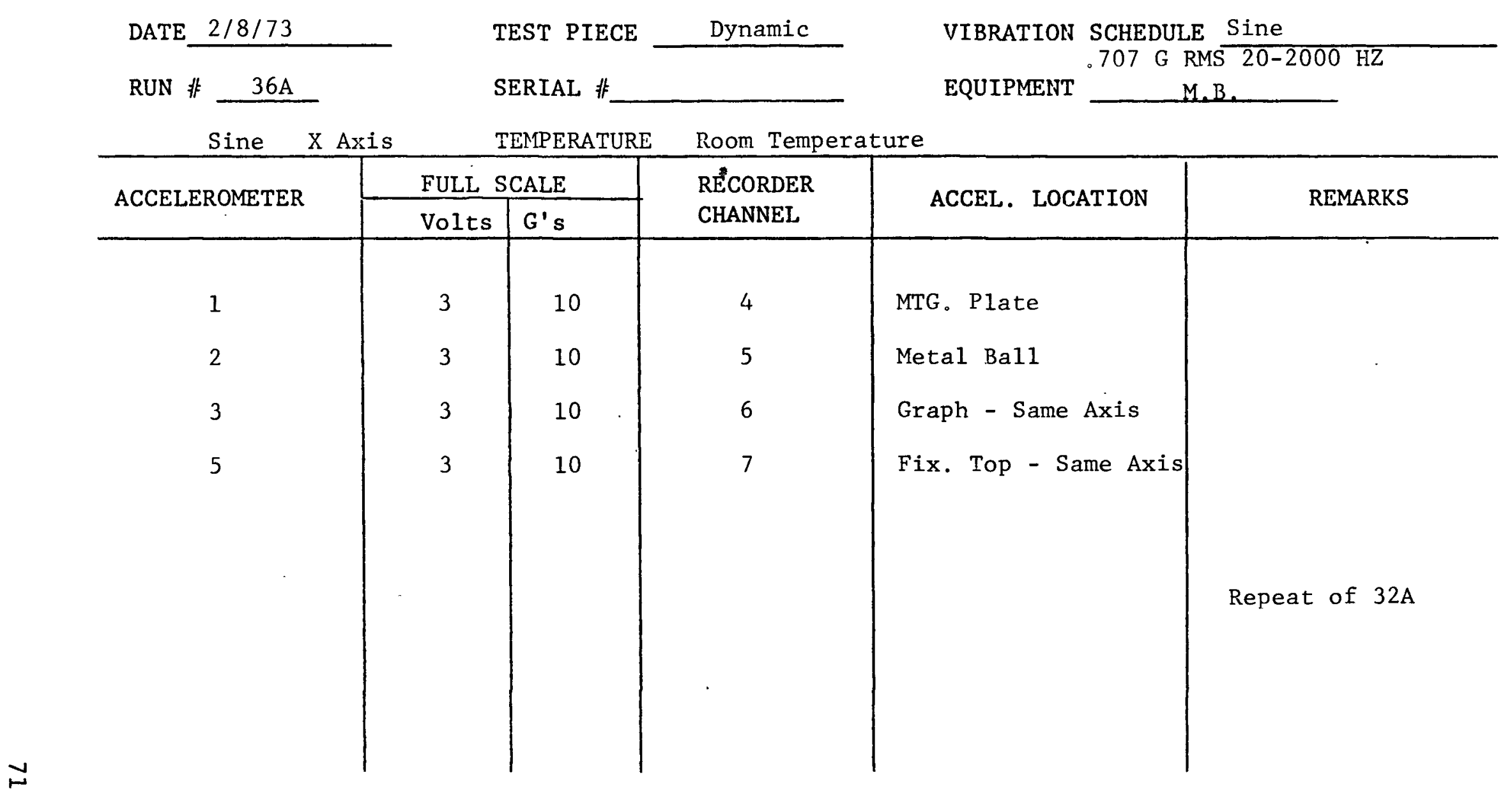




\section{VIBRATION DATA SHEET}

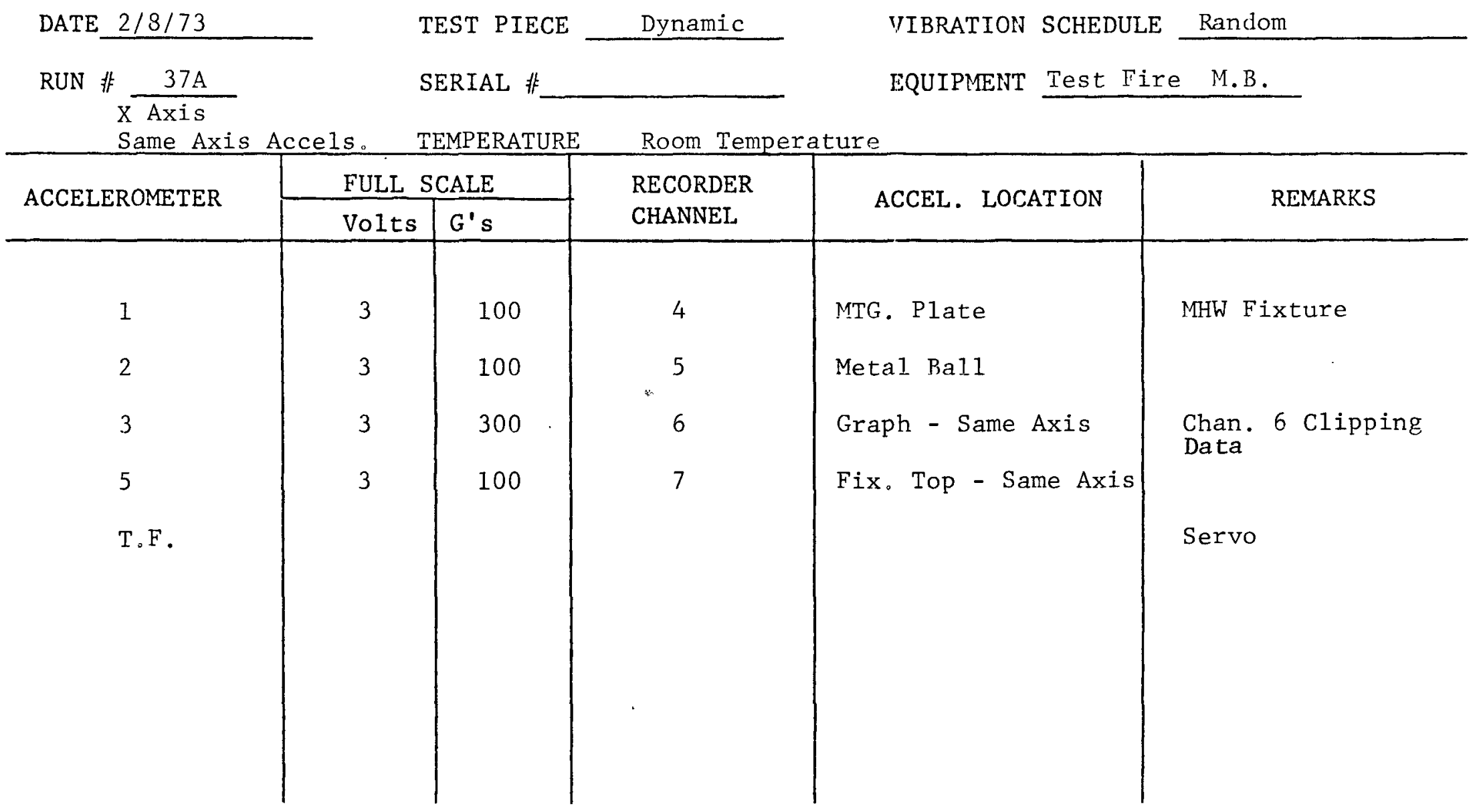




\section{VIBRATION DATA SHEET}

DATE $2 / 14 / 73$

RUN 非 $38 \mathrm{~A}$
TEST PIECE

SERIAL

TEMPERATURE
Dynamic

Room Temperature

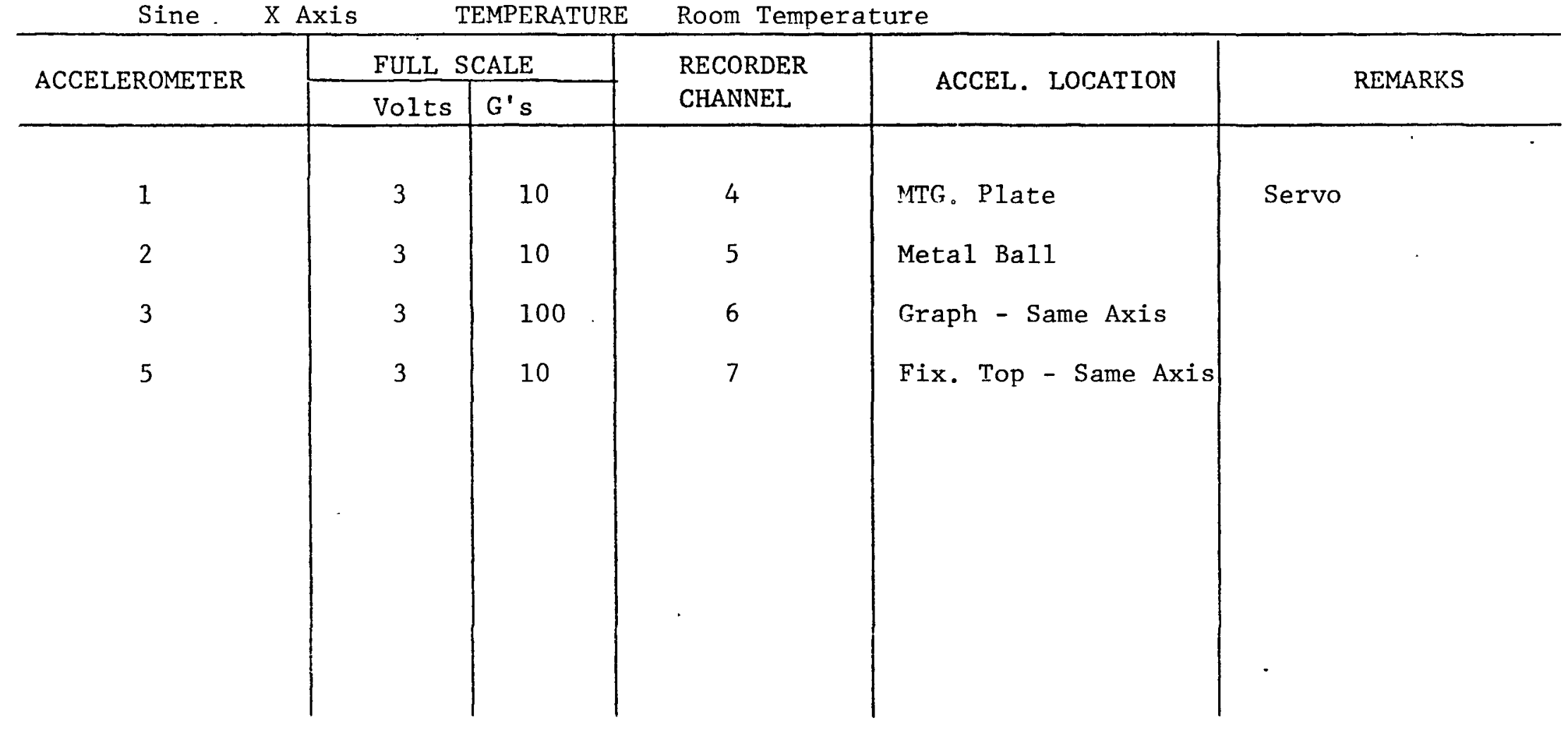

VIBRATION SCHEDULE Sine $.707 \mathrm{G}$ RMS 20-2000 HZ EQUIPMENT $\mathrm{M} . \mathrm{B}$. 


\section{VIBRATION DATA SHEET}

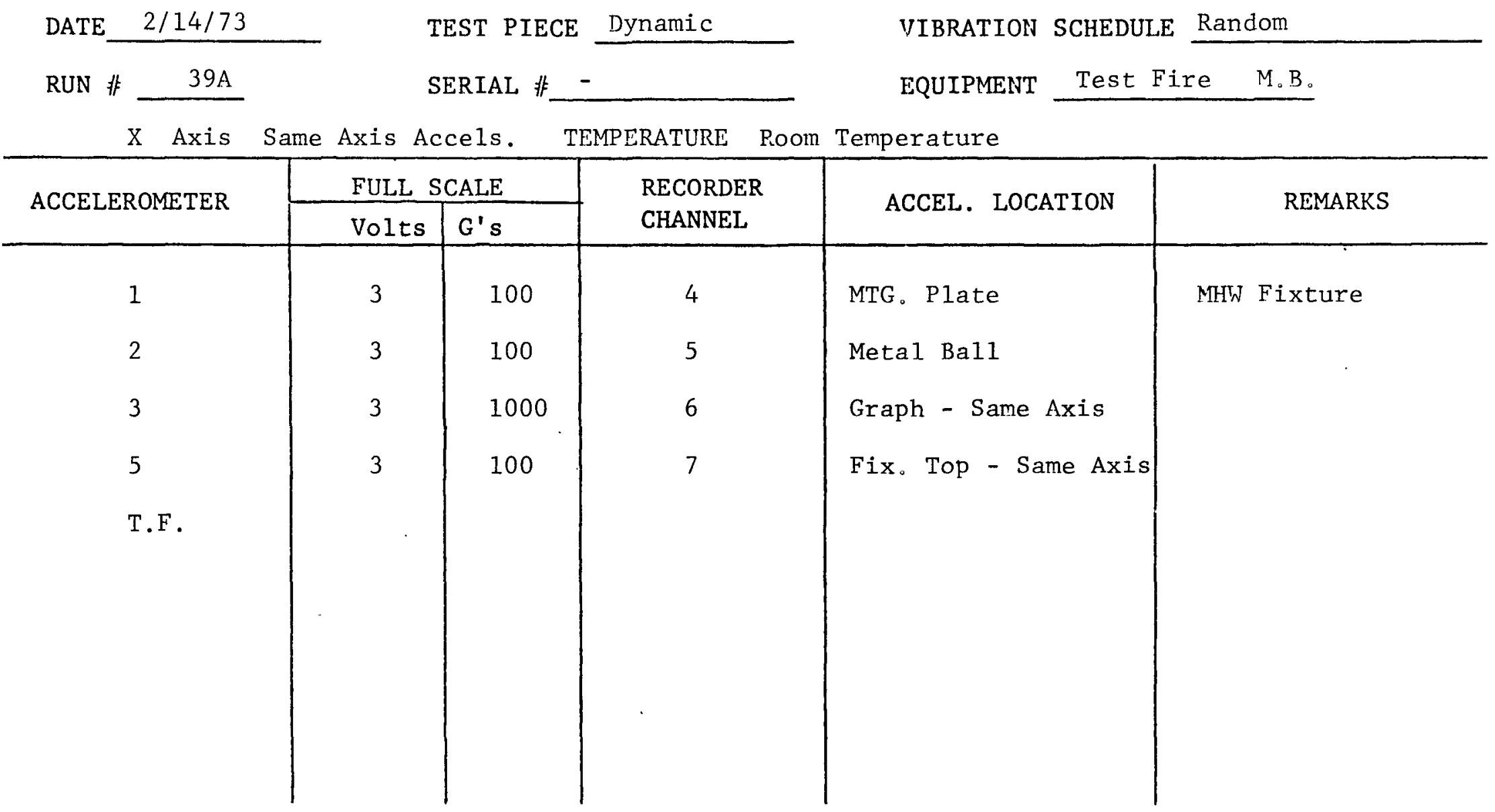




\section{VIBRATION DATA SHEET}

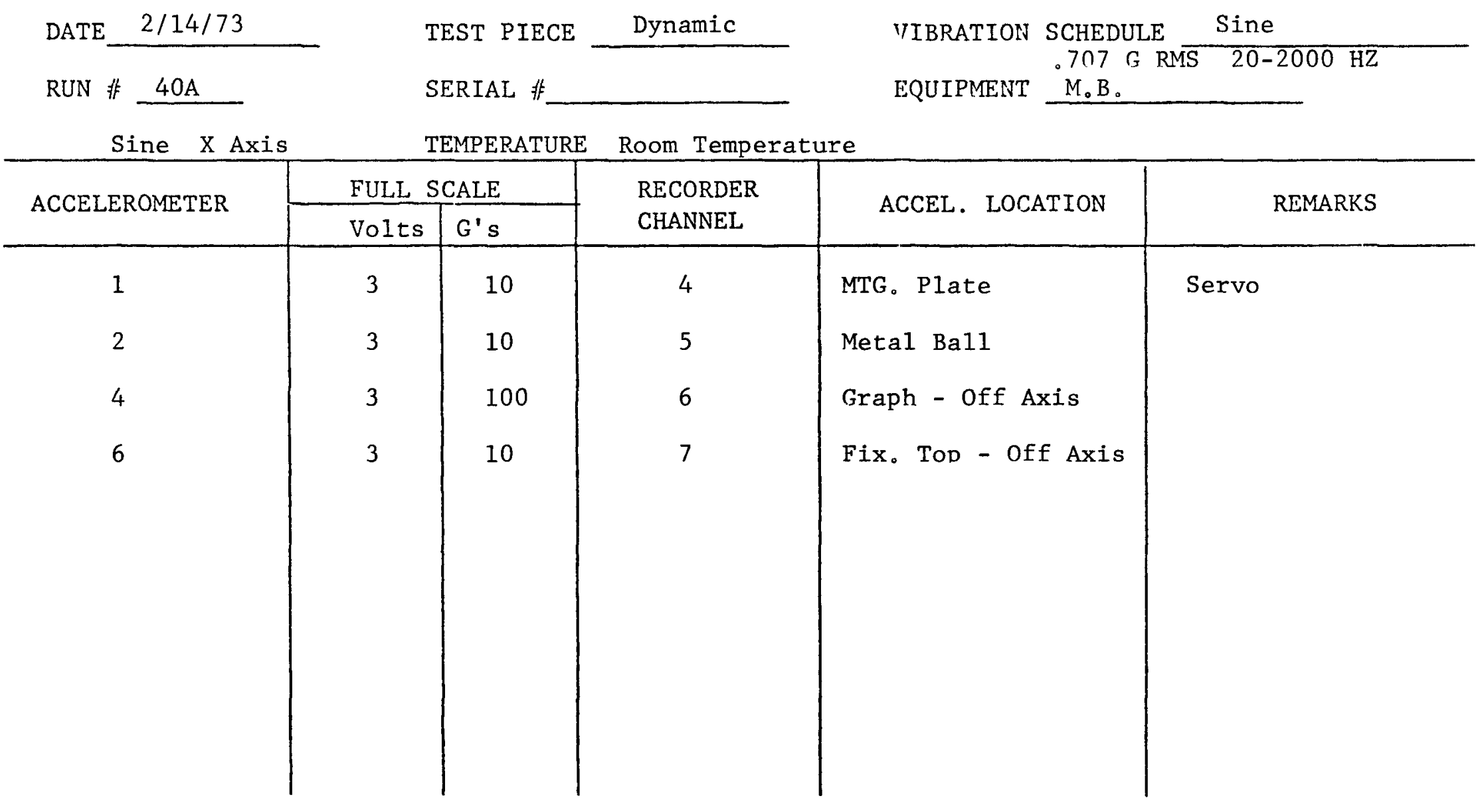




\section{VIBRATION DATA SHEET}

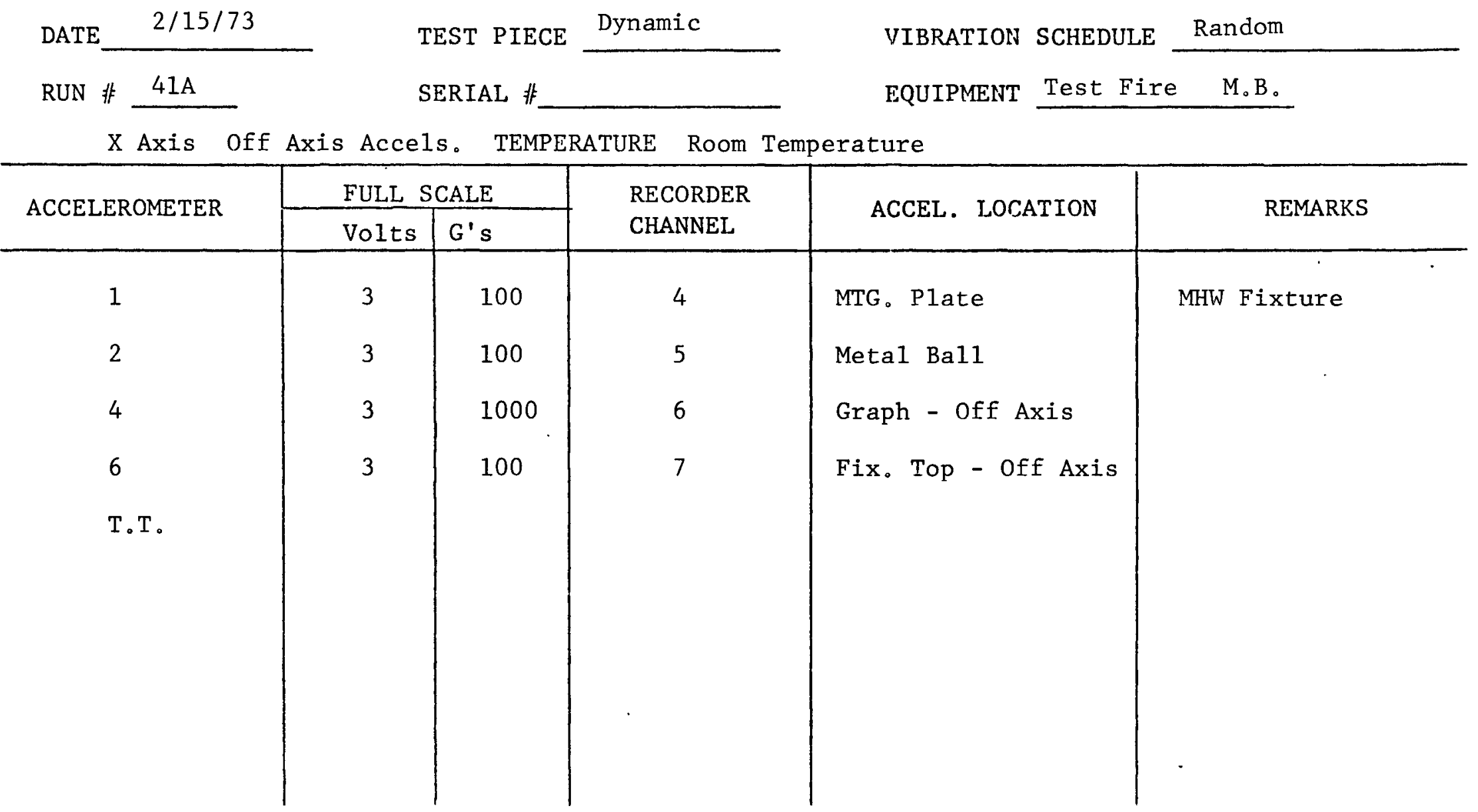




\section{VIBRATION DATA SHEET}

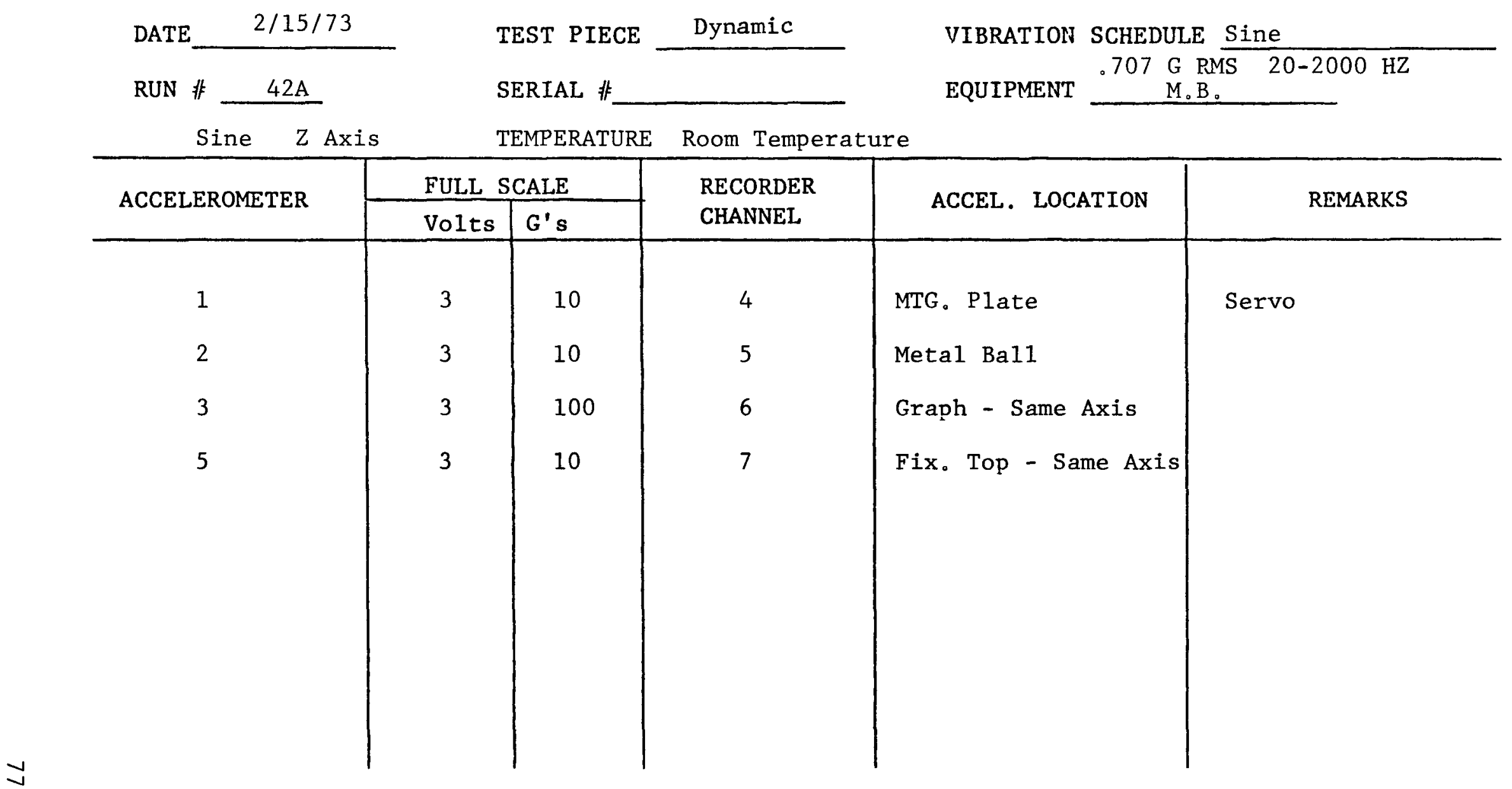




\section{VIBRATION DATA SHEET}

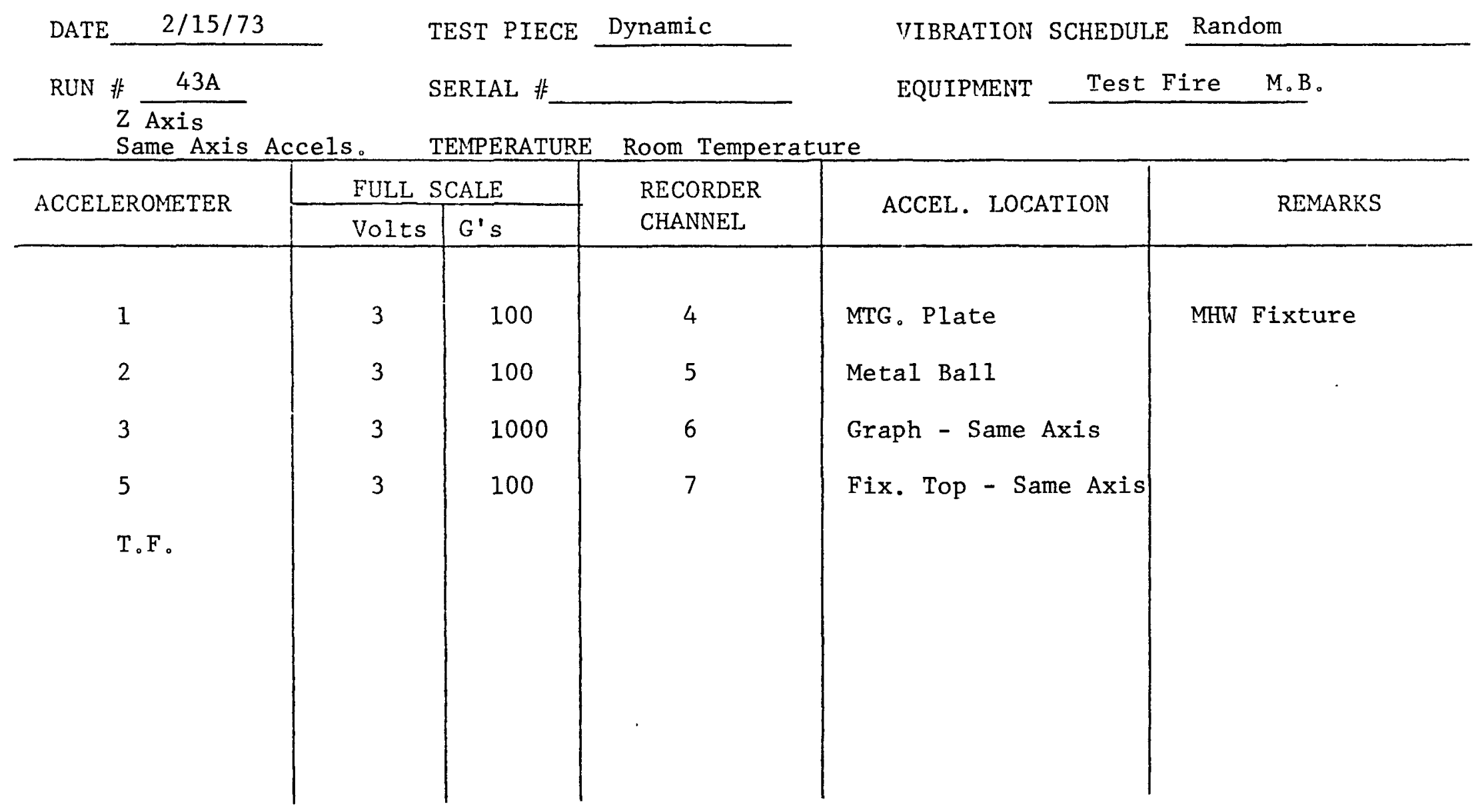




\section{VIBRATION DATA SHEET}

DATE 2/15/73 TEST PIECE Dynamic $\quad$ VIBRATION SCHEDULE $\frac{\text { Sine }}{.707 \mathrm{G} \text { RMS }}$

RUN \# $44 \mathrm{~A}$

SERIAL 非

EQUIPMENT

$\mathrm{M}$. B 。

Sine $Z$ Axis TEMPERATURE Room Temperature

\begin{tabular}{|c|c|c|c|c|c|}
\hline \multirow{2}{*}{ ACCELEROMETER } & \multicolumn{2}{|c|}{ FULL SCALE } & \multirow{2}{*}{$\begin{array}{l}\text { RECORDER } \\
\text { CHANNEL }\end{array}$} & \multirow{2}{*}{ ACCEL. LOCATION } & \multirow{2}{*}{ REMARKS } \\
\hline & Volts & G's & & & \\
\hline 1 & 3 & 10 & 4 & MTG. Plate & Servo \\
\hline 2 & 3 & 10 & 5 & Metal Ball & \\
\hline 4 & 3 & 100 & 6 & Graph - Off Axis & \\
\hline 6 & 3 & 10 & 7 & Fix. Top - Off Axis & \\
\hline
\end{tabular}




\section{VIBRATION DATA SHEET}

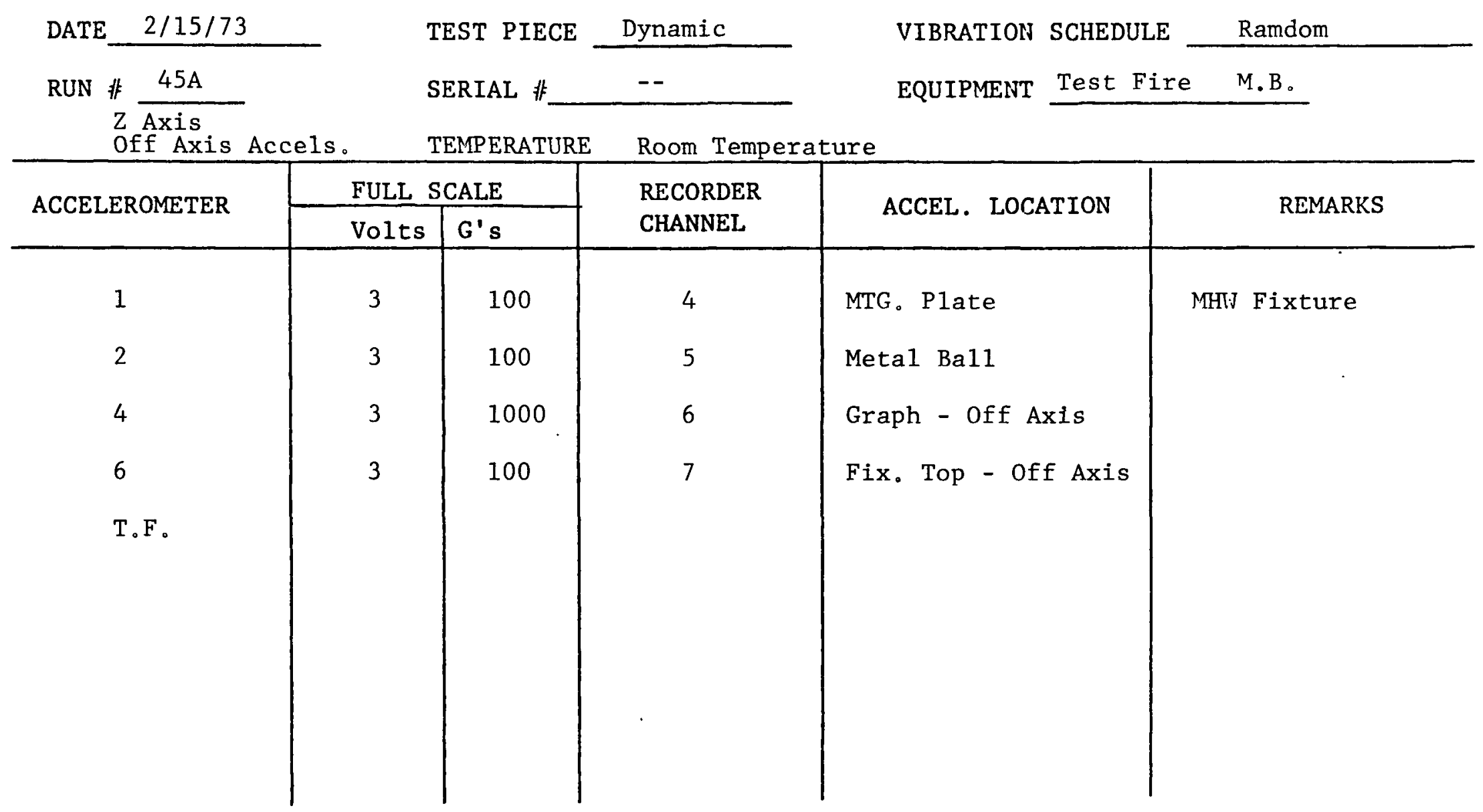




\section{VIBRATION DATA SHEET}

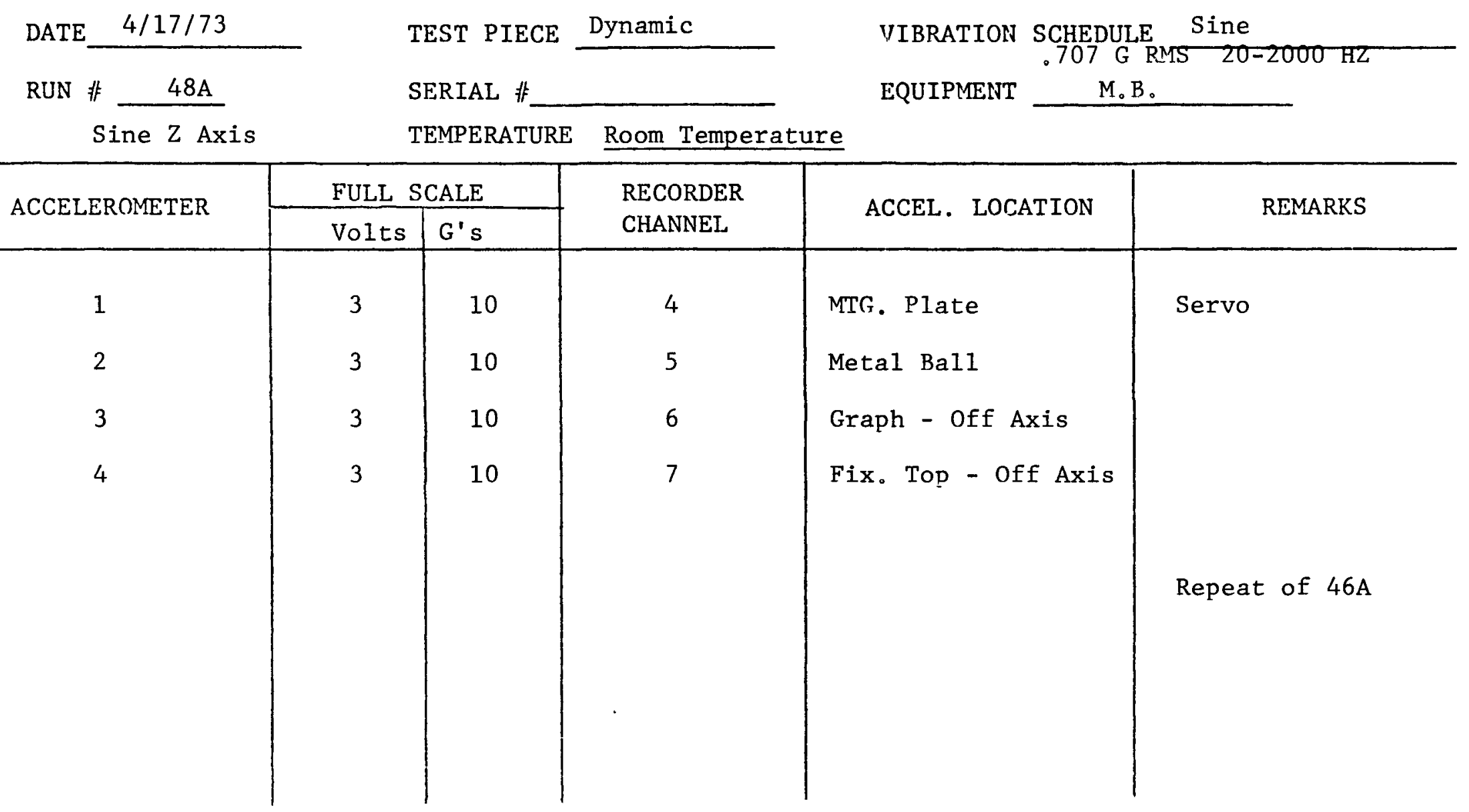


VIBRATION DATA SHEET

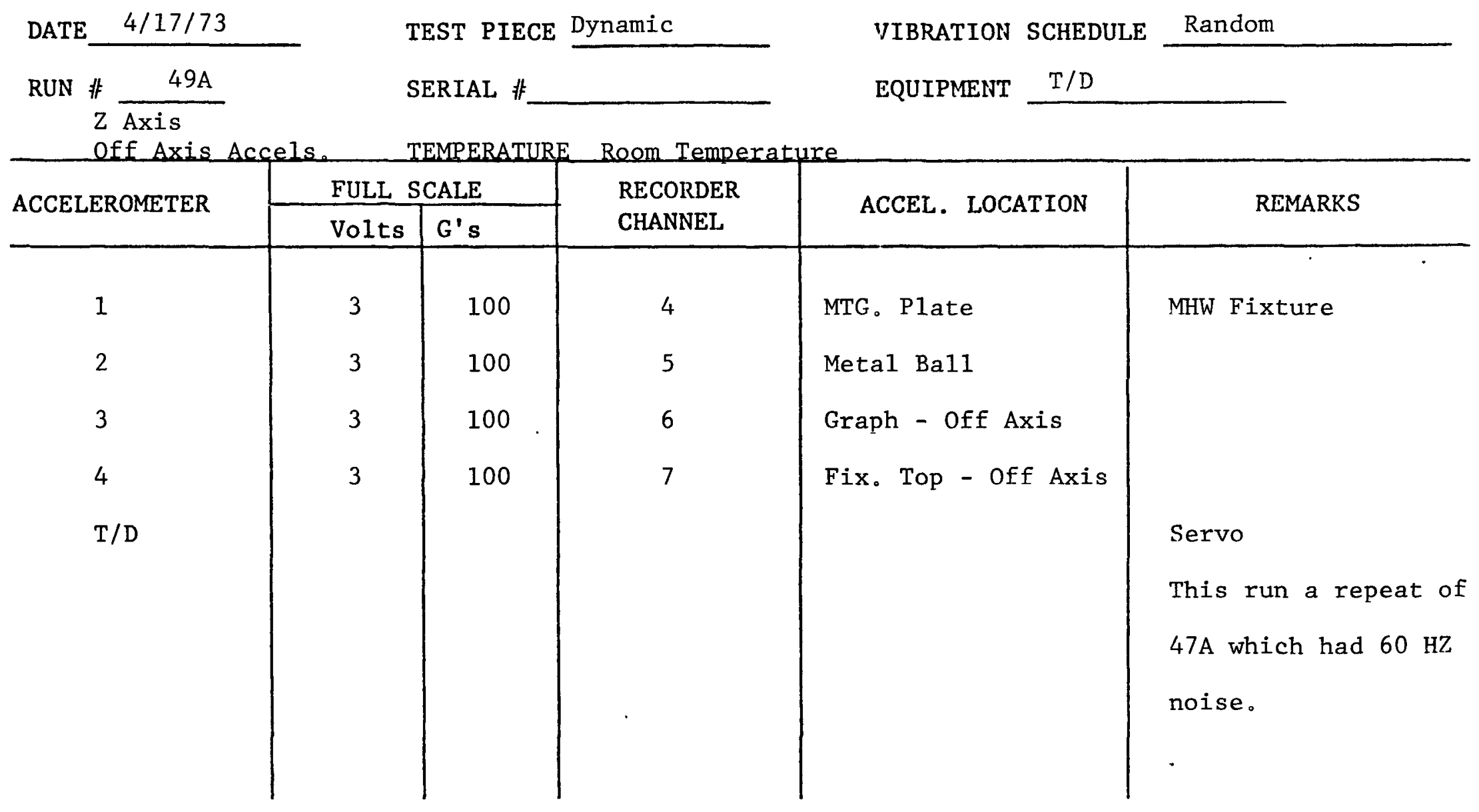




\section{VIBRATION DATA SHEET}

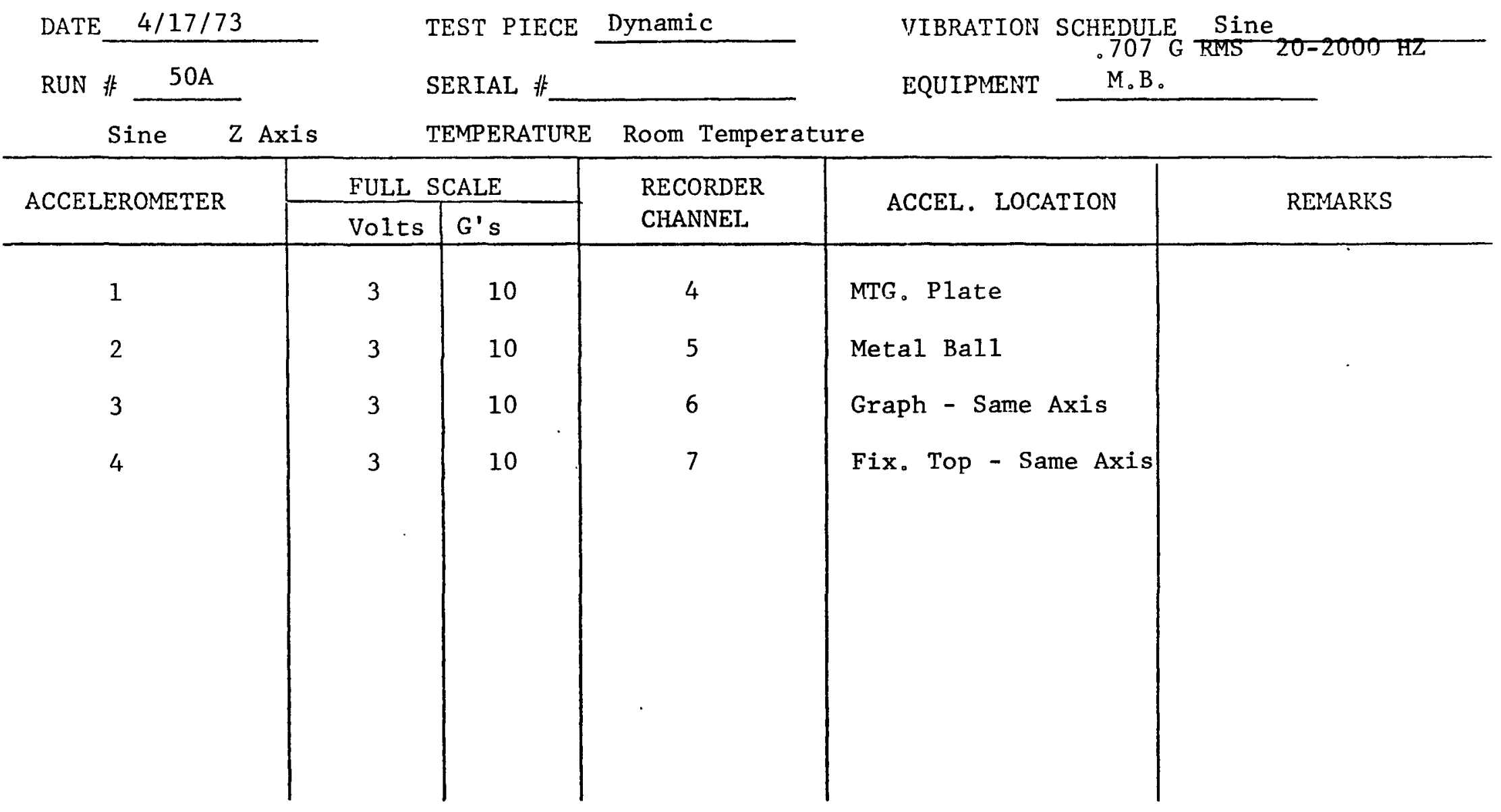


VIBRATION DATA SHEET

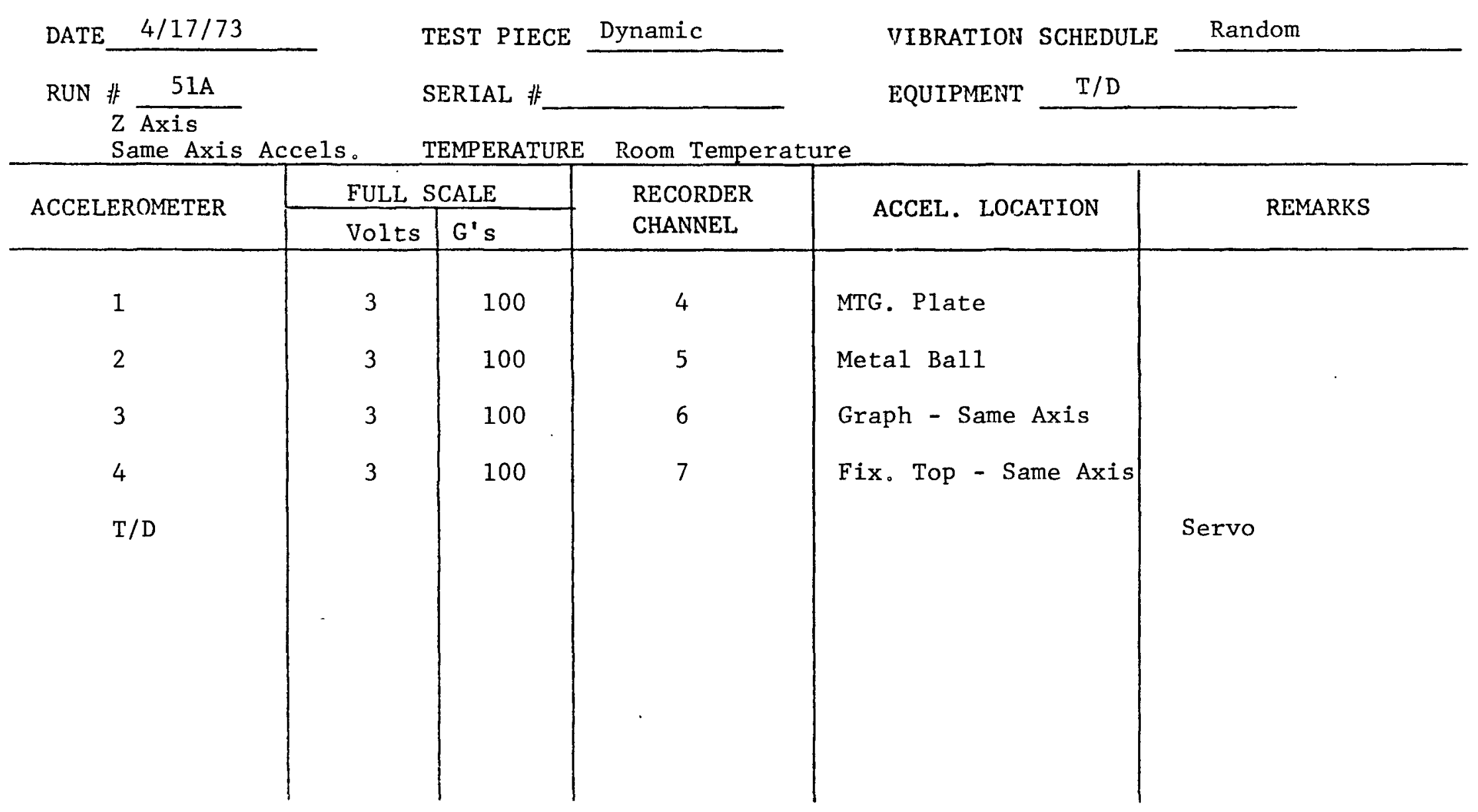




\section{VIBRATION DATA SHEET}

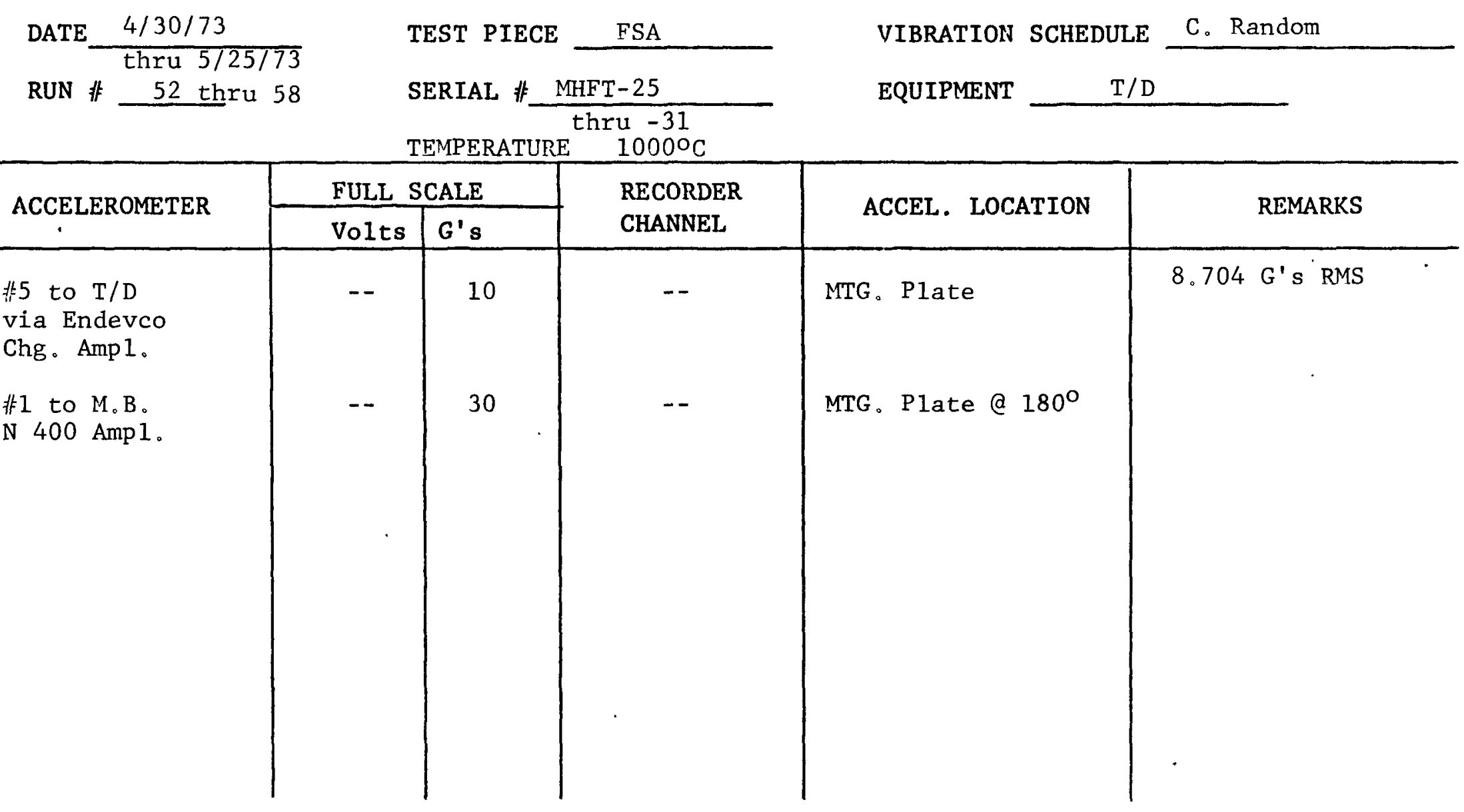


Blank page 
RANDOM SCHEDULE $C$

MHFT-25 THROUGH -31

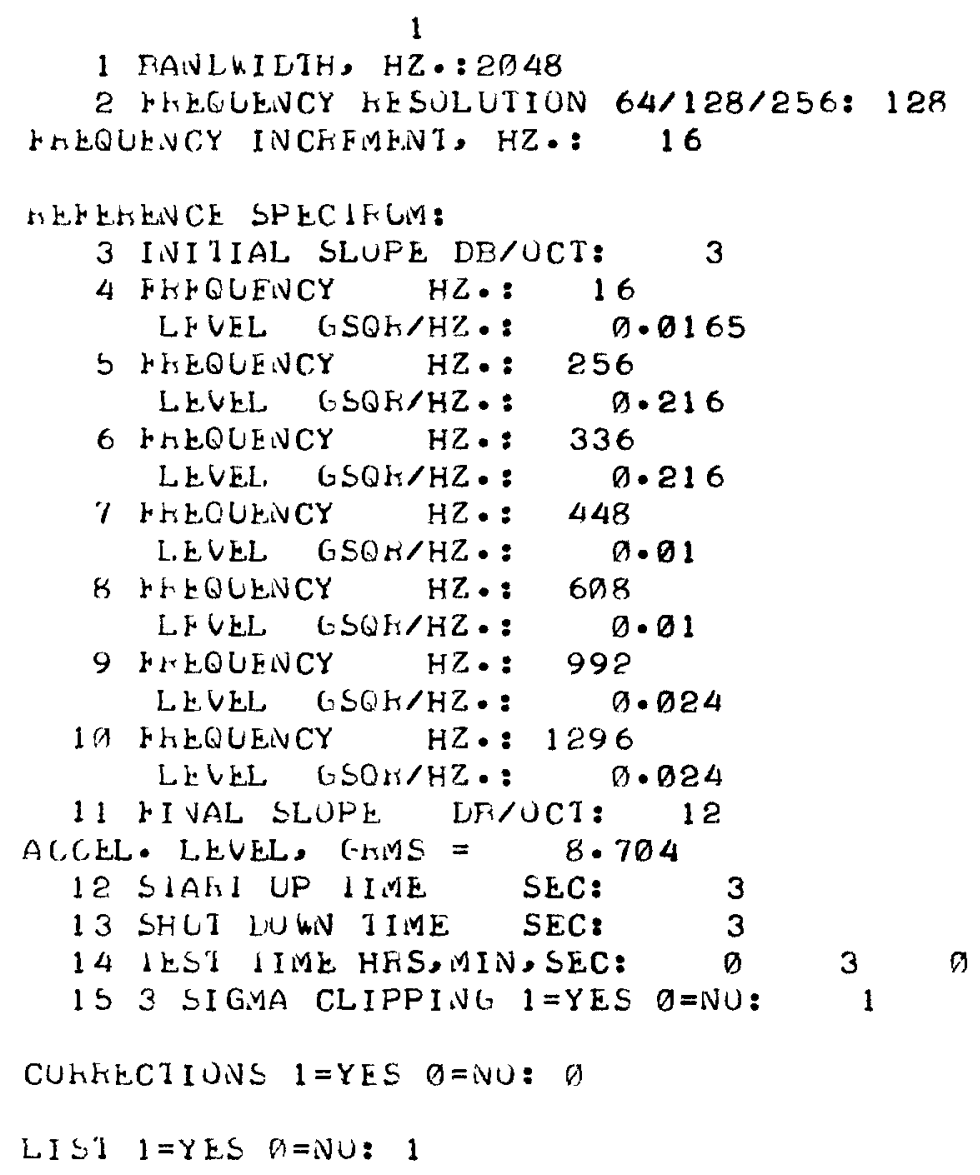


$\infty$

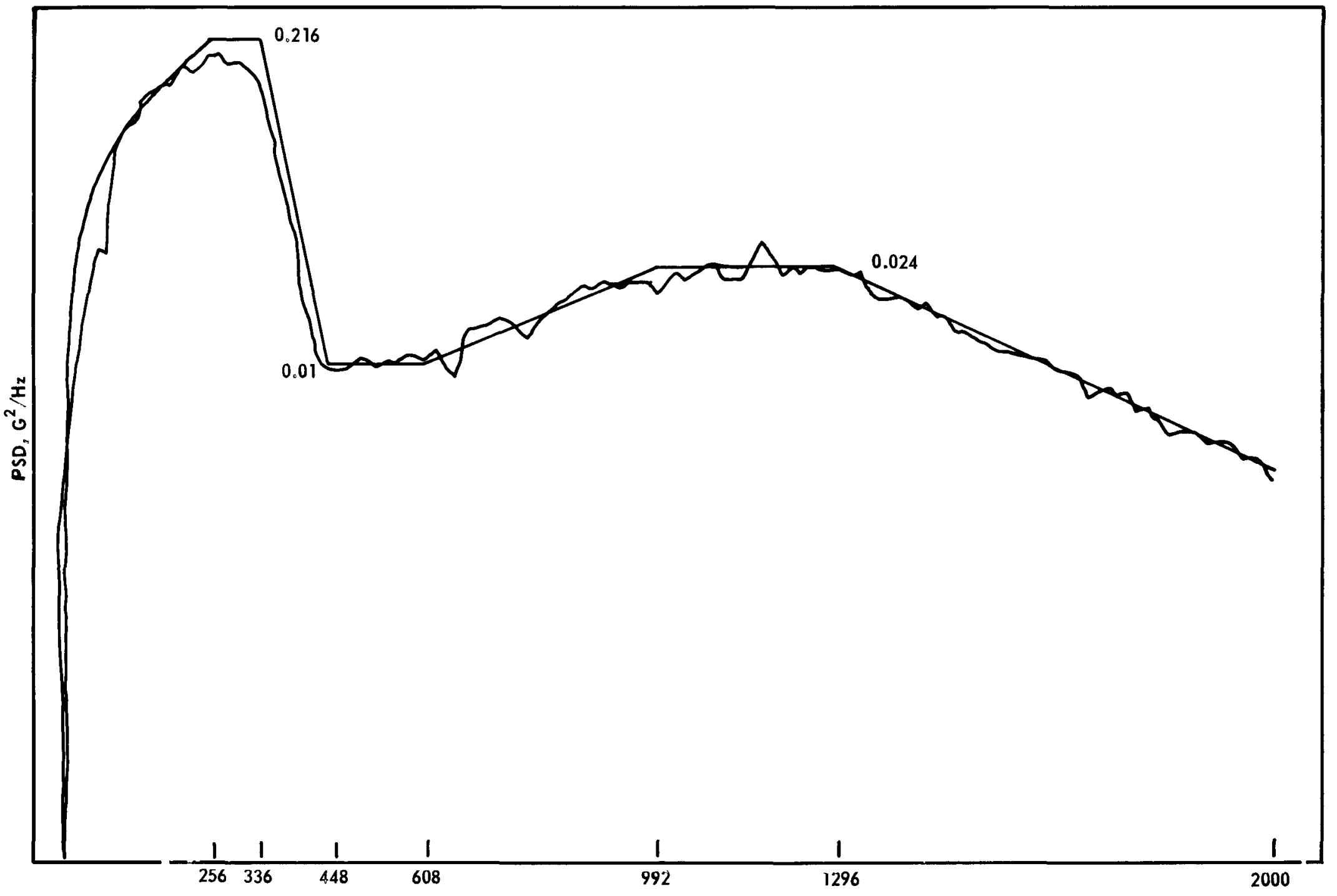

Frequency $\mathrm{Hz}$

FIGURE 20 - Random run for MHFT-30, typical for MHFT-25 to 31. 


\section{RADIOGRAPHS AND PHOTOGRAPHS}

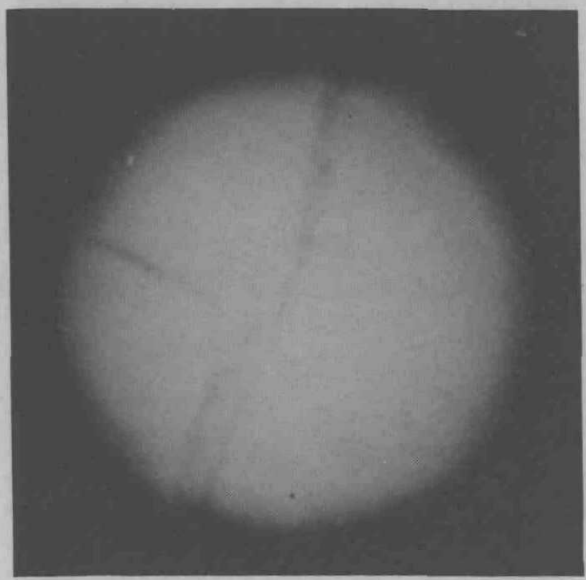

MHFT - 25

o $\mathrm{Vi}$ iew

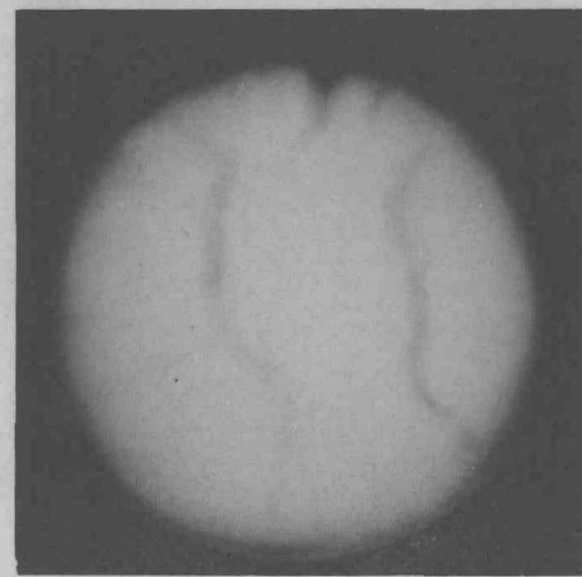

MHFT - 26

o ${ }^{\circ}$ iew

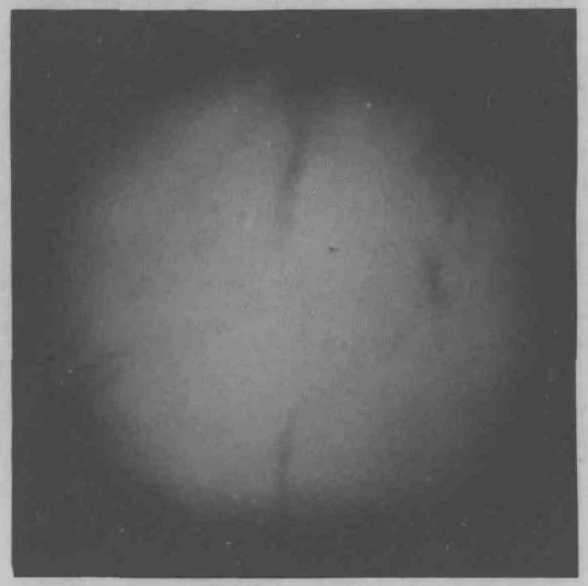

MHFT- 25

$90^{\circ}$ View

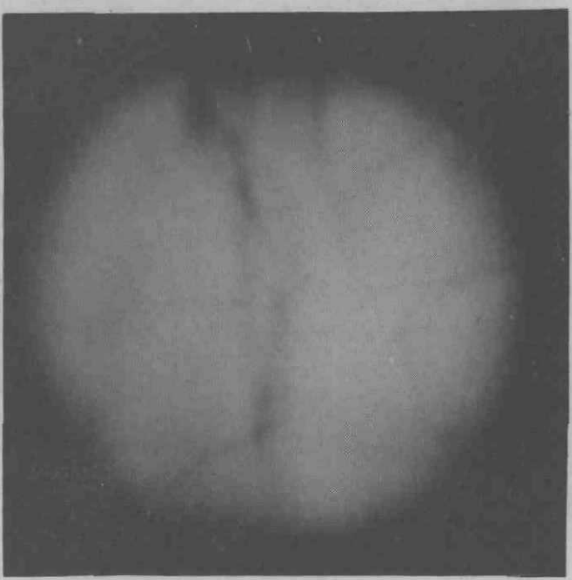

MHFT- 26

$90^{\circ}$ View

FIGURE 21 - Radiographs of safety sequential test capsules MHFT-2 5 and -26 after vibration. 


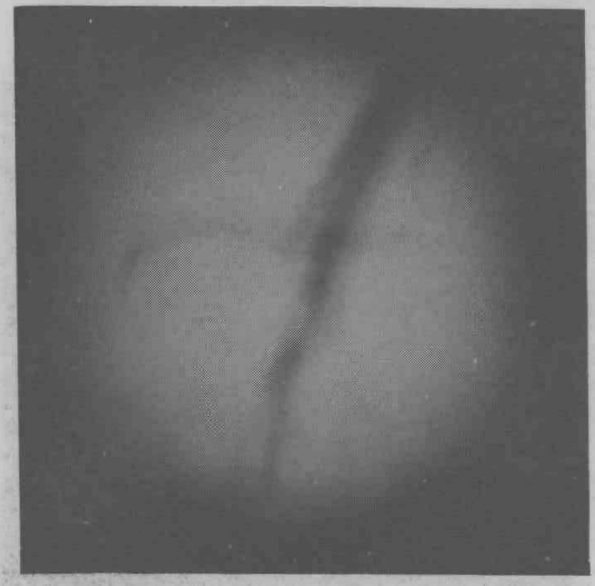

MHFT- 27

$0^{\circ}$ View

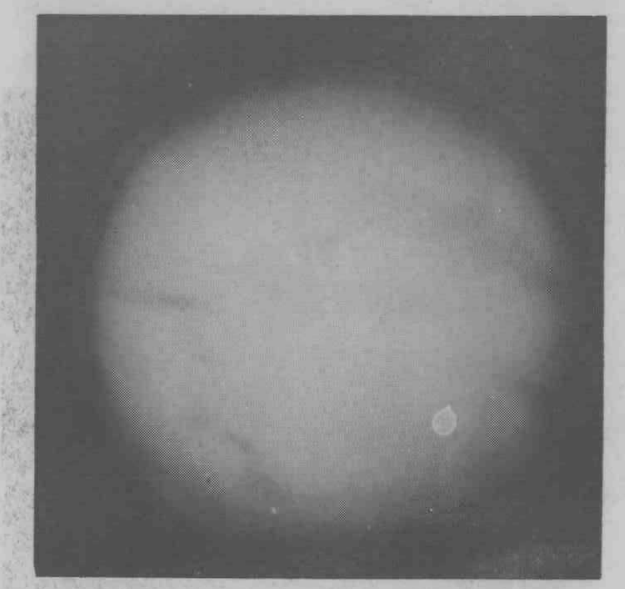

MHFT -28

$0^{\circ}$ View

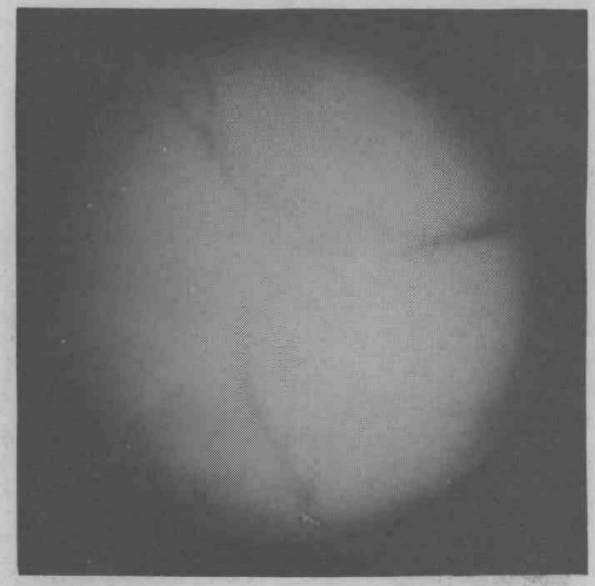

$M H F T-27$

$90^{\circ}$ View

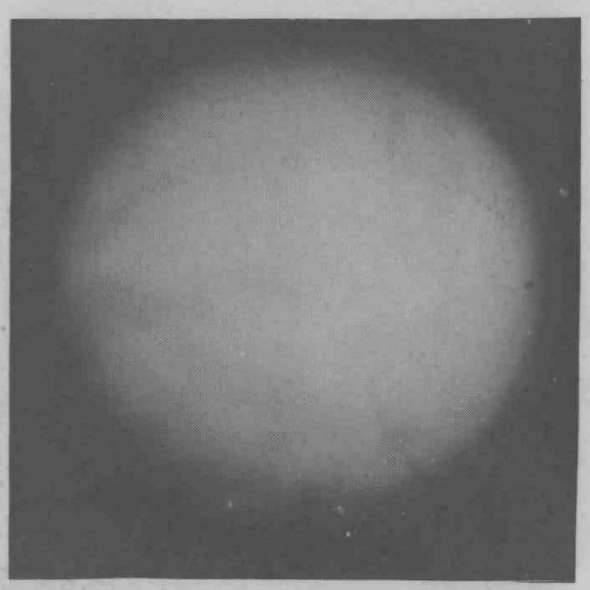

MHFT -28

$90^{\circ}$ View

FIGURE 22 - Radiographs of safety sequential test capsules MHFT-2? and -28 after vibration. 


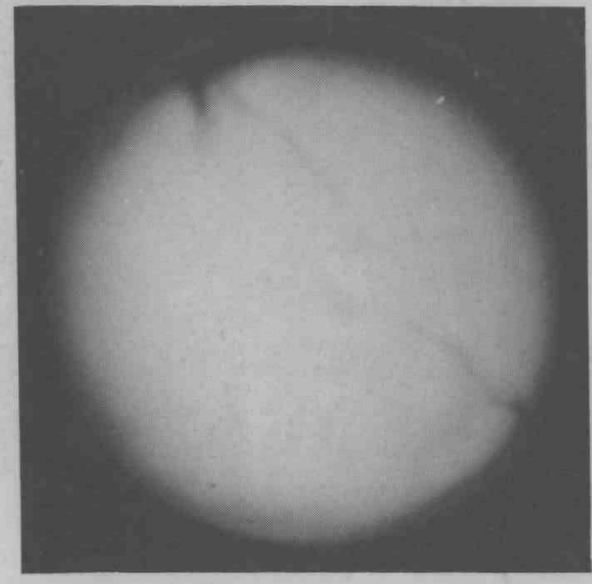

MHFT- 29

$0^{\circ}$ View

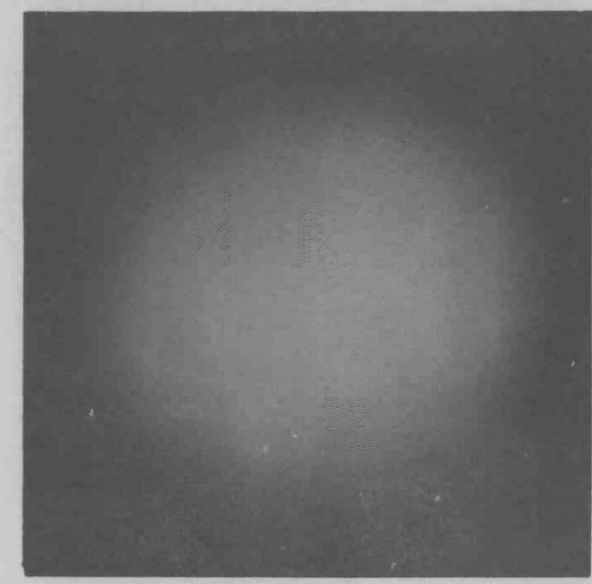

$M H F T-30$

$0^{\circ}$ View

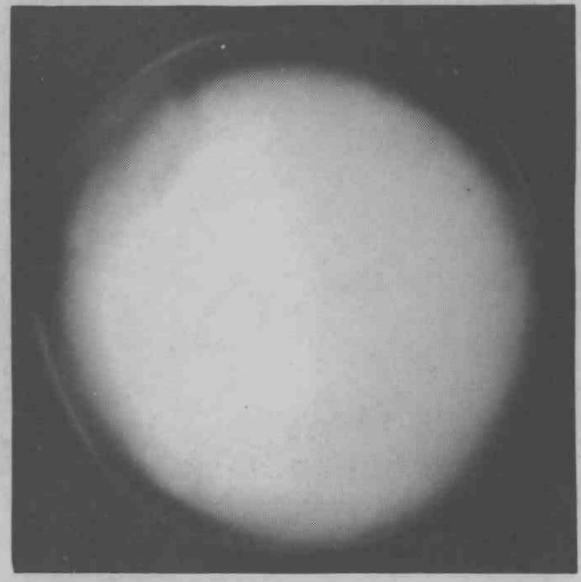

$M H F T-29$

$90^{\circ}$ View

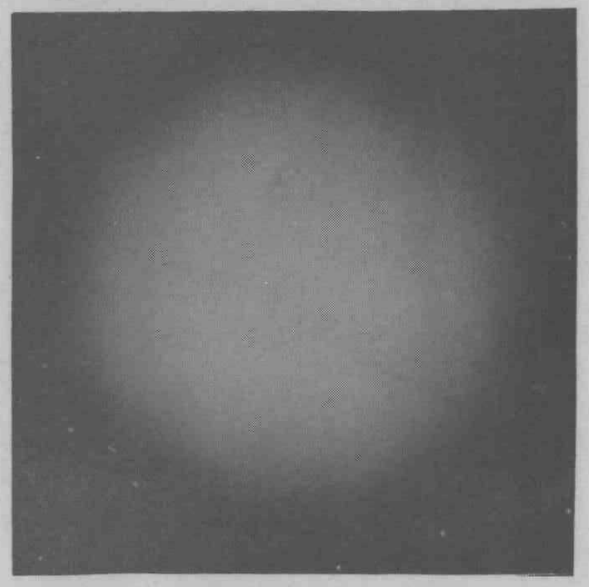

MHFT -30

$90^{\circ}$ View

FIGURE 23 - Radiographs of safety sequential test capsules MHFT-29 and -30 after vibration. 


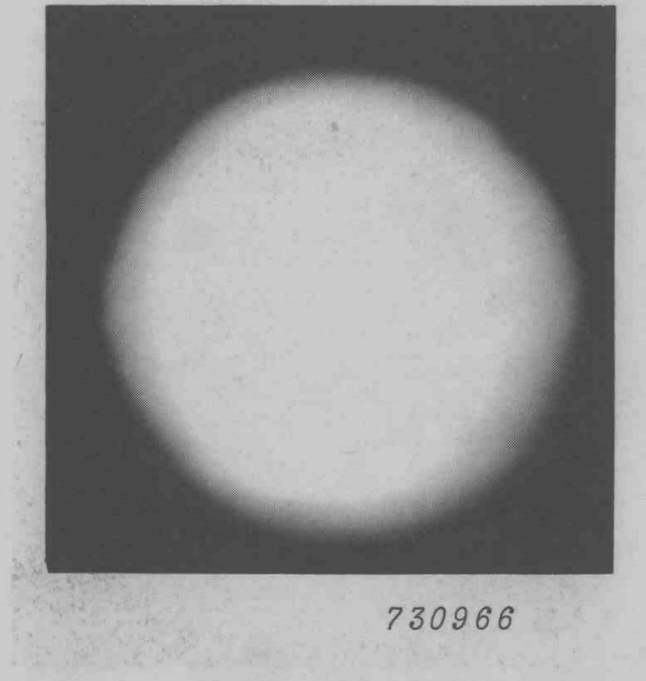

MHFT -31

$0^{\circ}$ View

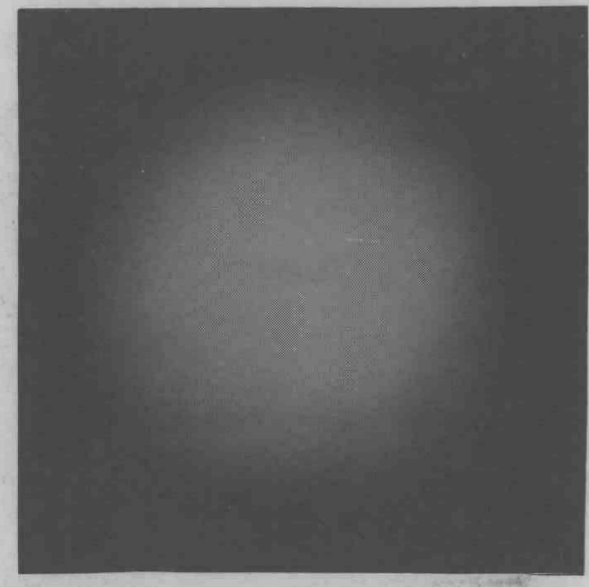

730967

$M H F T-31$

$90^{\circ}$ View

FIGURE 24 - Radiographs of safety sequential test capsule MHFT-31 after vibration. 


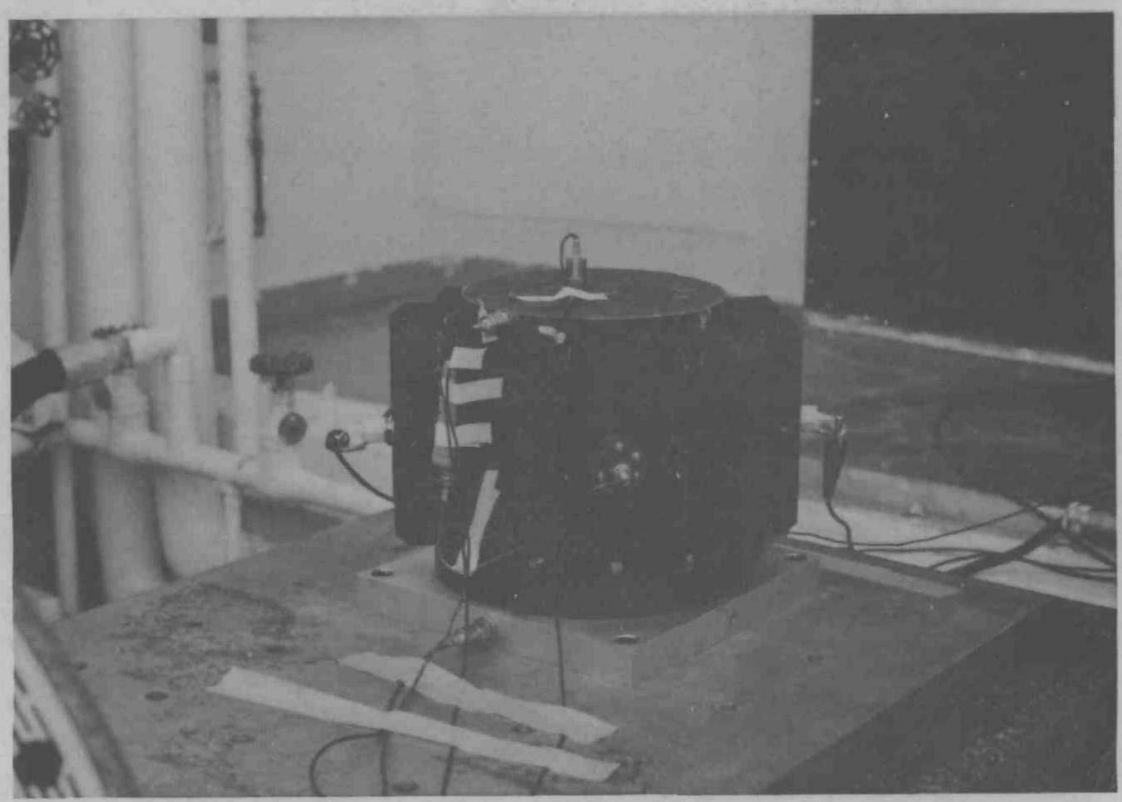

FIGURE 25 - MHW vibration test fixture.

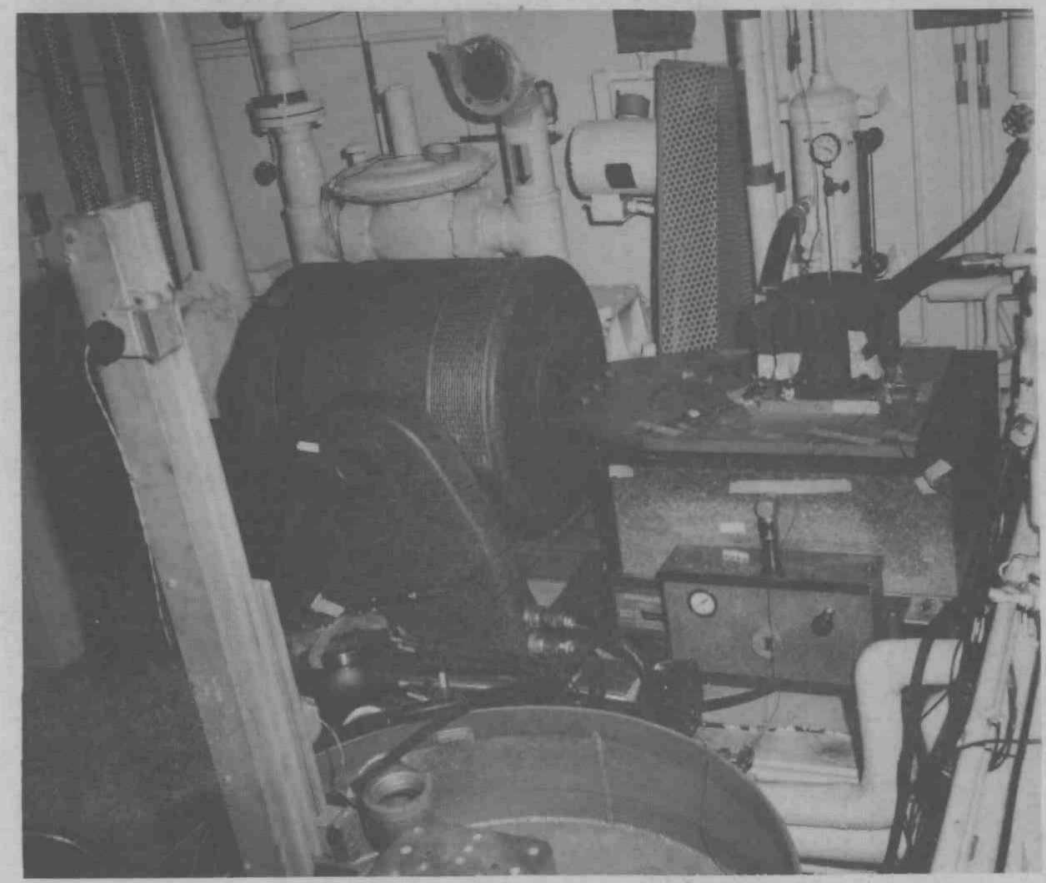

FIGURE $26-C-21$ vibration shaker. 


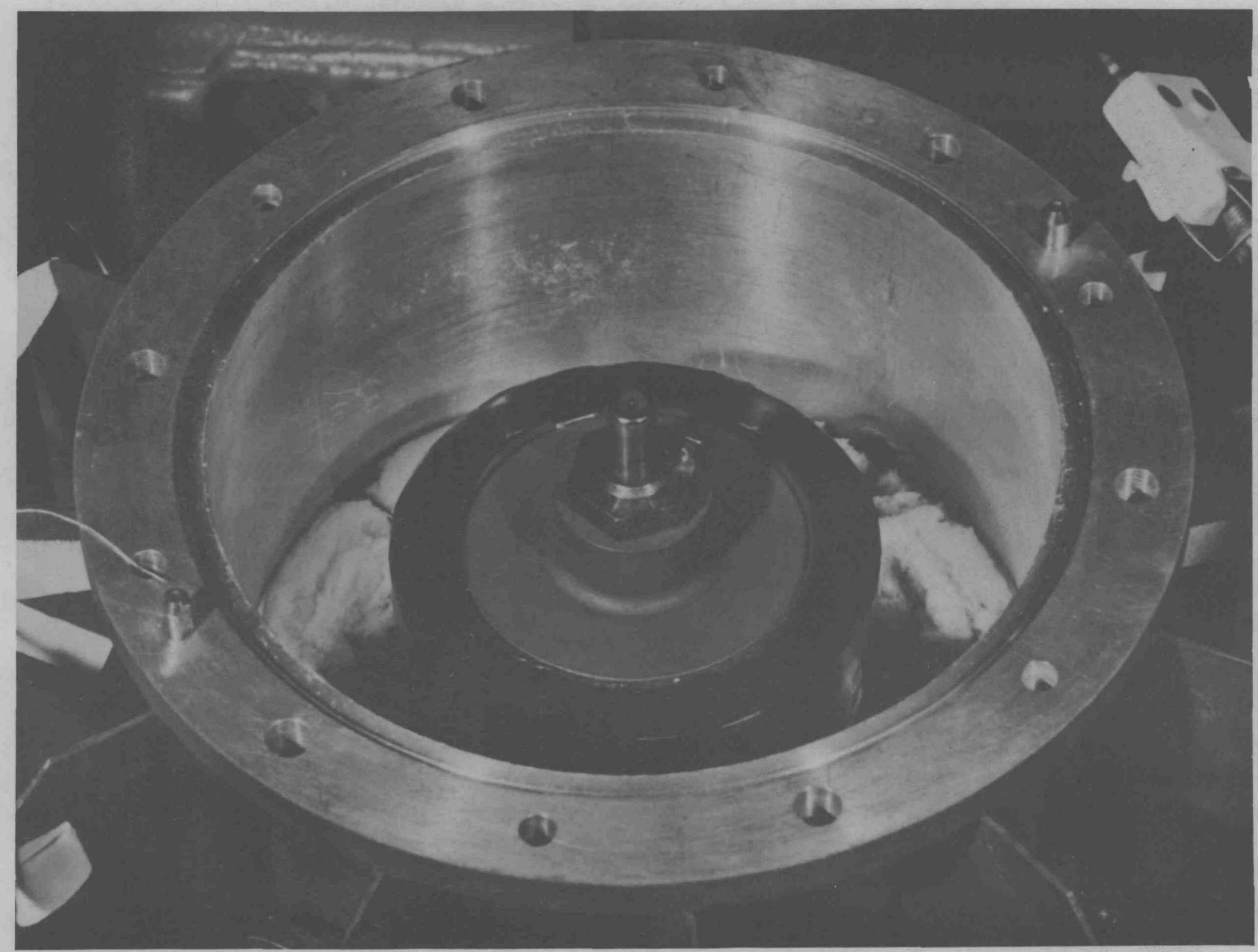

FIGURE 27 - Lid for vibration fixture graphite container. 


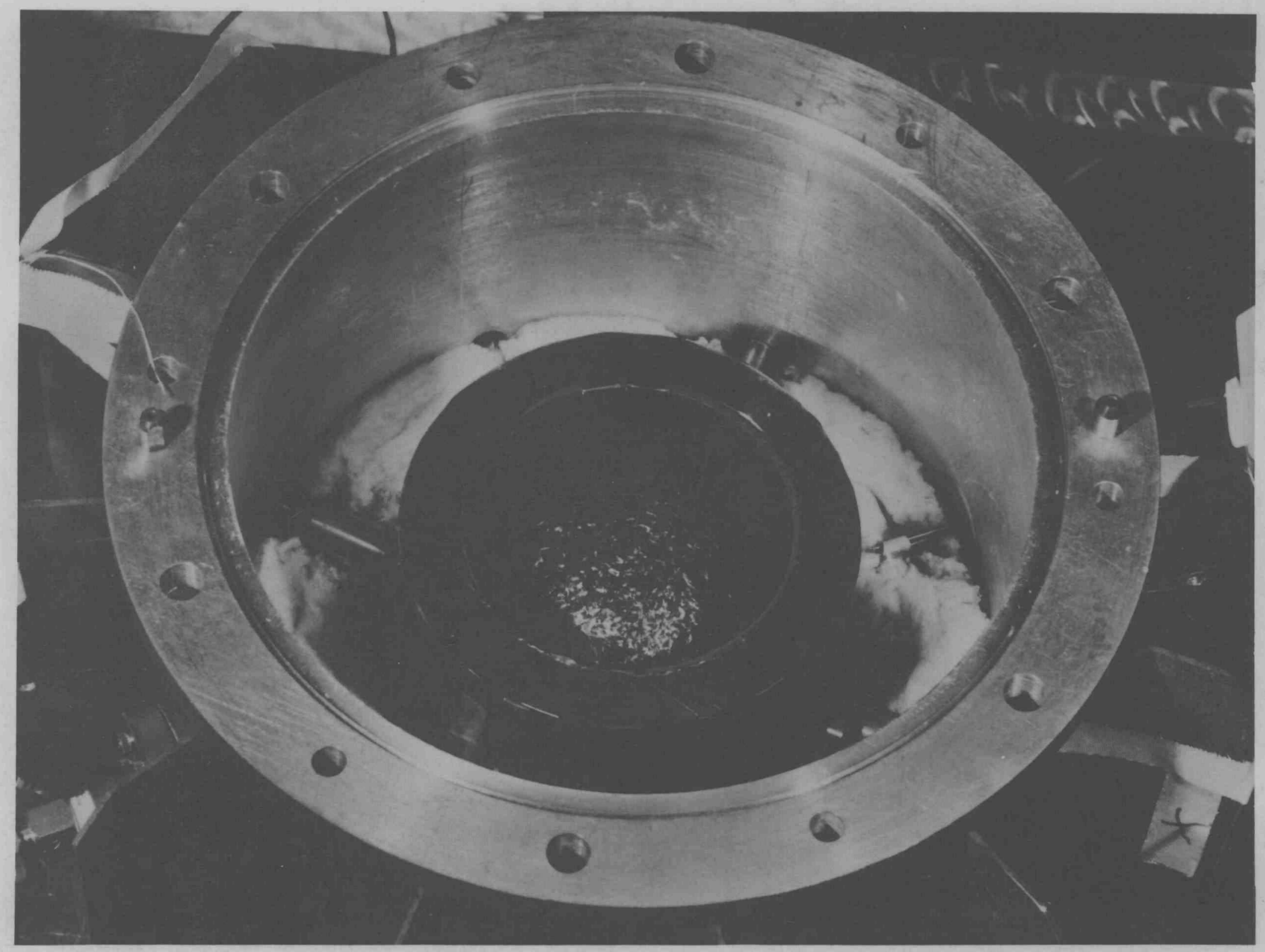

